\title{
NOTULEN
}

V A N D E

\section{ALGEMEENE EN BESTUURSVERGADERINGEN}

\author{
V A N H E T
}

\section{KONINKLIJK INSTITUUT \\ VOOR DE}

TAAL-, LAND- EN VOLKENKUNDE VAN NEDERLANDSCH INDIË.

$$
1886-' 87 .
$$




\section{VERSLAG}

VAN DEN

\section{STAAT EN DE WERKZAAMHEDEN}

VAN HBY

\section{KONINKLIJK INSTITUUT VOOR DE TAAL-, LAND- EN VOLKENKUNDB VAN NED.-INDIE OVBR 1886}

UTTGEBRACHT IN DE ALGEMEENE VERGADERING, GRHOUDEN DEN $26^{n}$ FEBRUARI 1887.

\section{Mijne Heeren!}

Waar het Bestuur ingevolge de voorschriften van het Reglement opnieuw zich geroepen ziet verslag te geven van den staat en de voornaamste lotgevallen en werkzaamheden onzer Instelling over het afgeloopen jaar, is het voor hem, die het voorrecht heeft als Secretaris, namens het Bestuur, de noodige mededeelingen te moeten doen, eene behoefte vó́r alles Uwe toegevendheid in te roepen. Is het voor deze Vergadering wellicht wat eentoonig reeds jaren achtereen telkenmale denzelfden verslaggever te moeten aanhooren, voor dezen is het zeker evenmin eene benijdenswaardige taak opnieuw de tolk des Bestuurs te moeten zijn, te minder waar, afgescheiden nog van den telkens wederkeerenden arbeid, bovendien daaraan dit nadeel verbonden is, dat door de publiciteit, die er telkens aan het verhandelde in de Bestuursvergaderingen gegeven wordt, verscheidene bijzonderheden, waarvan de mededeeling of kennisneming voor de leden anders nog eenige aantrekkelijkheid zou hebben, hun thans reeds bekend zijn.

Vergunt daarom Uwen verslaggever, ten einde niet in eene noodelooze herhaling te vervallen van veel wat reeds op andere wijze ter kennis van de leden is gebracht, te dezer gelegenheid zich tot eenige mededeelingen, meest herinneringen, te mogen bepalen.

$\mathrm{Z}_{\mathrm{ij}}$ zijn deels van treurigen, deels van blijmoedigen aard. Dit geldt zoowel met opzicht tot de personen, die tot onze Instelling in 
betrekking hebben gestaan en staan, als van de zaken, die er gedurende den afgeloopen tijdkring werden behandeld.

Wat onzen eigen kring, dien van het Bestuur, betreft, zij aangeteekend, dat na Uwe keuze in de vorige Algemeene Vergadering de heeren Kern en Bool met Uwen Secretaris in het Bestuur werden vervangen door de heeren E. B. Kielstra, Prof. G. K. Niemann en Dr. C. Snouck Hurgronje. Onze Ondervoorzitter, mr. W. Ridder van Rappard, werd tot Voorzitter verkozen, wiens plaats ingenomen werd door den heer S. van Deventer, terwijl het medelid J. H. de Groot met de thesaurie belast bleef; en meende het Bestuur opnieuw gebruik te moeten maken van zijne bevoegdheid om Uwen verslaggever, al was hij uit het Bestuur getreden, als Secretaris te handhaven, waar hij, blijkens de Notulen der Bestuursvergadering van 13 April 1872 het voorrecht zal hebben binnen weinige weken gedurende een tijdperk van 15 achtereenvolgende jaren onafgebroken met het secretariaat belast te zijn geweest, zij het hem vergund te dezer gelegenheid zijne dankbare waardeering voor de steeds ondervonden welwillendheid uit te spreken.

Jammer dat in onzen kleinen kring de rouw moest intreden. Was het voor ons een oorzaak van smart, nu bijna vijf maanden geleden, de mare te vernemen, dat ons voormalig bestuurslid, de hoogleeraar J. J. Meinsma, dien wij zoo gaarne aan ons hadden willen verbinden, ons door den dood ontvallen is: Gij allen weet, M. H., welk een slag ons den 4en Februari jl. weder getroffen heeft door het overlijden van onzen geëerden medebestuurder, Meinsma's ambtgenoot, de hoogleeraar Dr. A. W. T. Juynboll, in den ouderdom van nauwelijks 53 jaren. Verliest de Delftsche Instelling een harer bekwaamste docenten, die haar wetenschappelijk vaandel steeds hoog ophield, ook wij mogen dankbaar zijn levendige belangstelling in ons Instituut erkennen en zijne goede diensten, ons bewezen, op prijs stellen. Zagen wij hem telkens met vreugde in onzen kring wederkeeren, gaarne luisterden wij steeds naar zijne adviezen, met eenvoud en bescheidenheid door hem voorgedragen, doch waarin tevens zijne rijke gaven, degelijke geleerdheid en wetenschappelijke ernst uitblonken. Werden vele Indische tijdschriften door hem met zijne taal- en letterkundige studiën op Oostersch gebied bevoordeeld, ook onze "Bijdragen" verrijkte hij met menig opstel dat getuigenis gaf van zijne veelzijdige taalkundige kennis en hem tevens doet kennen als een grondig beoefenaar van het Moslemsch recht.

Nauwelijks was de groeve van dezen betreurden medebestuurder 
gesloten, of de mare kwam tot ons van het overlijden van een ander lid uit onzen kring; de heer Robidé van der Aa ontviel ons den 10en Februari jl. Jaren achtereen was hij aan onze Instelling verbonden, als bestuurder waarvan hij telkens in ons midden wederkeerde. Tal van adviezen en rapporten in onze vergaderingen, niet weinige bijdragen in ons tijdschrift, een aantal afzonderlijke werken door ons met zijne voorlichting en onder zijne leiding uitgegeven, bewijzen zijne onvermoeide werkzaamheid op Indologisch wetenschappelijk terrein.

Laat ons, M. H. te dezer gelegenheid van beide deze onze Medebestuurders afscheid nemen, met het ernstig voornemen, om hunne nagedachtenis te eeren door op hun voetspoor met ijver en plichtsbetrachting de ons toevertrouwde belangen onzer Instelling te behartigen!

Zijn door het onverwacht overlijden van Dr. Juynboll en van der Aa twee buitengewone vacatures ontstaan, waarin wij $U$ straks zullen noodigen te voorzien, tot ons leedwezen is ook de tijd der aftreding van drie onzer andere medebestuurders, de hh. S. van Deventer, Dr. B. F. Matthes en Prof. Dr. G. A. Wilken aangebroken. Noode zien wij hen onzen kleinen kring verlaten. Waar ons Reglement hunne herkiezing verbiedt, aanvaarden zij de betuiging van onzen oprechten dank voor het vele dat zij ten bate van onze Instelling hebben willen verrichten, welke wij ons veroorloven in de voortduring hunner belangstelling aan te bevelen.

Kunt Gij met ons dezen geëerde medeleden een "tot weerziens" toeroepen, helaas! de dood heeft dit jaar vele van onze gewone leden weggerukt. Nevens Meinsma, Juynboll en Van der Aa, de Indische ingenieur R. Everwijn, de oud-Resident G. du Rij van Beest Holle, de voormalige chef der Indische Staatsspoorwegen, D. Maarschalk, de oud-Agent der Javasche Bank, tevens een onzer oudste leden, D. Scheltema, de kerkelijke hoogleeraar aan de Rijks-Universiteit te Utrecht, Dr. E. H. Tasonder, de bekende natuurkundige en reiziger in Madagascar Dr. François P. L. Pollen. Smart het ons hunne namen van onze ledenlijst te moeten afvoeren, met leedwezen vernamen wij tevens van enkele anderen, dat zij om redenen van persoonlijken aard zich gedrongen zagen hun ontslag als leden van het Instituut te nemen.

Moest door deze verliezen het getal onzer contribueerende leden worden verminderd, het is een genoegen hierbij tevens te kunnen aanteekenen dat, op enkele uitzonderingen na, allen, wien wij in het afgeloopen jaar zoowel hier te lande als in Indië het 
lidmaatschap hebben aangeboden, dit gaarne hebben aanvaard. Daardoor onderging het cijfer van ons ledental wel eenige verandering, doch geene vermindering. Bedroeg het in het vorige jaar 379, de ledenlijst 1 wijst bij den aanvang van dit jaar het cijfer aan van 419 , waarvan 8 donateurs, 5 contribueerende Instellingen, 263 gewone leden in Nederland en 143 in Indië. Mocht wellicht dit laatste cijfer in veler oog te laag schijnen, vermeerdering daarvan is wellicht in den eersten tijd niet te voorzien, zoolang de gedrukte stemming onder de Europeesche maatschappij in Indië blijft voortduren. Het is ons echter eene ware voldoening hierbij te mogen aanteekenen, dat wij herhaaldelijk uit Indië vele ondubbelzinnige blijken van belangstelling in ons streven mochten ontvangen, dank zij vooral aan het krachtig en beleidvol optreden van onze Commissarissen in Indië, de heeren A. L. van Hasselt en D. Gerth van $W_{i j k}$, die geene gelegenheid doen voorbijgaan om zoowel de wetenschappelijke als finantieële belangen van onze instelling te bevorderen en waarvoor zij met recht op Uwe en onze erkentelijkheid aanspraak mogen maken.

Aan blijken van sympathie voor en waardeering van onzen arbeid zoowel in het binnen- als buitenland heeft het ons overigens in het afgeloopen jaar niet ontbroken.

Herinnerd zij aan de tot ons gerichte uitnoodigingen van de directiën van het Verein für Naturkunde te Cassel en van het Verein für Erdkunde te Dresden tot deelneming aan de feestviering ter gelegenheid van het vijftig- en vijfentwintig-jarig bestaan dier Genootschappen, aan welke wij onze gelukwenschen hebben aangeboden; en terwijl het ons leed deed, geene vertegenwoordigers te hebben kunnen zenden ter vergadering van den $6^{n}$ Deutschen Geographentag in Dresden, zult Gij het zeker met ons waardeeren, dat onze medebestuurders, de hh. Schlegel en Snouck Hurgronje als afgevaardigden van het Instituut hebben willen optreden bij het in October 11 . te Weenen gehouden zevende Orientalisten-Congres. Laatstgenoemde geleerde mocht daarbij uit onzen naam aan het Bureau van het Congres een door hem bewerkte feestgave aanbieden, bestaande in eene keurige verhandeling over de Mekkaansche spreekwoorden, welke blijkens de "Munchener Allgemeine Zeitung" van 13 October jl. de aandacht der deskundigen heeft getrokken, terwijl de schrijver zelf, van wien in evengemeld orgaan eene "biografische

\footnotetext{
${ }^{1}$ Bijlage I, thans bijgewerkt tot Maart jl.
} 
Notiz" wordt geleverd, omtrent de werkzaamheden van het congres een uitvoerig verslag gegeven heeft in een tweetal nummèrs van "de Nieuwe Rotterdamsche Courant", waarvan een exemplaar ter inzage voor belangstellenden in onze Bibliotheek is nedergelegd.

Hierbij zij tevens aangeteekend, dat van meer dan eene aflevering onzer Bijdragen telkens in buitenlandsche tijdschriften beredeneerde overzichten voorkomen; gewezen zij o. a. op de aankondigingen in "Le Muséon", het "Literarische Centralblatt" , de "Deutsche LiteraturZeitung" en "Trübner's American, European and Oriental Literary Record". Is deze bespreking van onzen arbeid ons welkom, wij hopen, dat dit voorbeeld ook gevolgd moge worden door onze vaderlandsche pers, aan wier hoofdorganen onzerzijds telkens een exemplaar van ons tijdschrift wordt gezonden.

Doch al moge het niet als een overdreven eisch worden gesteld dat er ten onzent eenige meerdere waardeering zij van den belangeloozen arbeid onzer vaderlandsche geleerden ten bate van Indië, bij overschatting soms, ter andere zij, van wat daaromtrent in den vreemde verricht wordt, - het is ons aangenaam te mogen vermelden, dat de verkoop onzer werken, althans wanneer men het eigenaardig karakter daarvan in aanmerking neemt, geene onbevredigende uitkomsten heeft opgeleverd. Uit de door de firma Nijhoff aangeboden rekening en verantwoording over 1885 blijkt toch, dat de totale verkoop der werken van het Instituut eene som bedroeg van $f 2368.90$, waarvan, na aftrek der administratie-kosten, ten onzen bate een saldo aanwezig was van $f$ 1413.94. Wij houden ons overtuigd, dat, nu er ook in Indië een depôt onzer werken is gevestigd en daar met meer kracht dan vroeger wordt geëxploiteerd, de baten uit den verkoop onzer werken milder zullen vloeien, althans onze raming verder overschrijden.

Vergunt ons hieraan eenige nadere mededeelingen van finantieëlen aard vast te knoopen.

Uit de rekening en verantwoording van het afgeloopen dienstjaar 1886, welke U straks met de noodige inlichtingen door den Penningmeester zal worden aangeboden met het rapport van twee Uwer medeleden, zal U blijken dat de finantieële toestand van het Instituut niet onbevredigend mag genoemd worden. Beliepen de ontvangsten en uitgaven de sommen van $f 7798.22$ en $f 7568.39$, en sluit de rekening mitsdien met een saldo van $f 229.83$, bij dit gunstig resultaat mag nog gevoegd worden, dat onder de gedane uitgaven enkele posten voorkomen, die van het vorig dienstjaar 1885 zijn 
overgeschreven en eerst nu zijn bestreden geworden. Van nog niet vereffende rekeningen of achterstanden is thans geen sprake meer, terwijl het Bestuur zich tot dusver zooveel mogelijk beijverd heeft ons gebouw onbezwaard te doen blijven. Voorts zij $\mathrm{U}$ in herinnering gebracht, dat, terwijl het Instituut vroeger in het bezit was van eenig kapitaal, met een hypotheek op het gebouw, men gemeend heeft tot de algeheele aflossing dezer laatste te moeten overgaan, waarvoor men bij ontstentenis van andere fondsen het kapitaal zelf heeft moeten realiseeren.

Door een en ander is de kas van het Instituut nagenoeg geheel uitgeput, waardoor wij, met het oog op eenige oogenblikkelijke uitgaven, vreezen in ongelegenheid te zullen geraken; wèl hebben zich zoowel vroeger als nu weder eenige onzer medebestuurders bereid verklaard een voorschot tot het gevorderde bedrag te verleenen, doch het kwam het Bestuur, in overleg met onzen Penningmeester, voor meer in overeenstemming met de eischen van een ordelijk beheer eene onderhandsche geldleening tot een bedrag van $f 5,000$ te sluiten. Daarvoor is evenwel ingevolge het sub 10 van art. 10 van het Reglement Uwe machtiging noodig, welke te verkrijgen het doel is van het voorstel dat op het convocatie-btljet voor deze vergadering is omschreven.

Daaraan heeft het Bestuur gemeend een ander voorstel te moeten toevoegen tot wijziging van de 2 de alinea's van de artt. 8 en 9 , ten doel hebbende, om, evenals dit met het secretariaat kan geschieden, ook de thesaurie meer blijvend in eene en dezelfde hand te kunnen houden. Wij houden ons overtuigd, dat deze wetswijziging door het welbegrepen belang van het Instituut wordt geboden en verre de voorkeur verdient boven de periodieke wisseling van penningmeesters, gelijk die volgens de bestaande regeling wordt voorgeschreven.

Doch laat ons niet verder uitweiden over de mérites van de door het Bestuur ingediende voorstellen, die straks aan Uwe beslissing zullen worden onderworpen. Vervolgen wij liever onze herinneringen omtrent de fata van het Instituut in het afgeloopen jaar.

Volgens het Reglement moet het doel van het Instituut, de bevordering van de taal-, land- en volkenkunde van 's Rijks overzeesche bezittingen en koloniën, onder meer bereikt worden door het verzamelen van hetgeen daarover in druk bestaat of in handschrift te bekomen is, alsmede door het onderhouden van betrekkingen met andere wetenschappelijke instellingen en personen in Nederland, in Oost- en West-Indië en het buitenland. Ook in het afgeloopen 
jaar was het ons streven geweest, zooveel doenlijk, aan die bepaling gevolg te geven.

De lijst der binnen- en buitenlandsche academiën, geleerde genootschappen, instellingen en redactiën, waarmee wij in betrekking staan, is uitgebreider dan ooit te voren ${ }^{\mathbf{1}}$; telkens mochten wij voorstellen ontvangen om met een gevestigd of nieuw opgericht genootschap een letterkundig verkeer te openen, en waar het ons bleek dat zulk een verkeer goede vruchten zou kunnen opleveren voor het doel, dat wij beoogen, hebben wij er geen bezwaar in gezien aan het tot ons gericht verzoek te voldoen.

Verreweg de meeste genootschappen of vereenigingen beijveren zich met het Instituut in verbinding te blijven door geregelde toezending der uitgegeven werken. De Bibliothecaris stelt zich echter voor eerlang over te gaan tot eene revisie van de bestaande lijst der zusterinstellingen, waarmeê het Instituut door ruiling van wederzijdsche geschriften in betrekking staat. Het is hem namelijk voorgekomen, dat onderscheidene instellingen sedert geruimen tijd niets van haar werkzaamheden hebben doen blijken, en, waar hij geen reden heeft van twijfel aan haar voortdurend bestaan, zij in gebreke schijnen te zijn aan het Instituut hare periodieke uitgaven en verdere geschriften te doen toekomen. Maatregelen zijn bereids door hem genomen of zullen weldra volgen om die vereenigingen, welke in dit opzicht nalatig zijn gebleken, aan haar verzuim te herinneren.

Vooral door het dusver gevolgde stelsel van ruiling der uitgegeven werken wordt onze Bibliotheek zeer gebaat en ziet zij zich in het bezit gesteld van een aantal periodieken en afzonderlijke reeksen van geschriften, die langs anderen weg moeielijk of slechts zelden, en dan ook niet zonder groote kosten, te verkrijgen zijn.

Voor zoover onze geldmiddelen het toelaten, tracht de Bibliothecaris de leemten in de aan zijne zorgen toevertrouwde verzameling door aankoop van oude en nieuwe werken aan te vullen, doch, afgescheiden nog van de omstandigheid dat hij bij die aanvulling onzer Bibliotheek telkens ook te rade moet gaan met de behoeften en eischen van de in ons gebouw gevestigde en mede aan zijne zorg toevertrouwde boekverzameling van het Indisch Genootschap, behoeft het nauwelijks eenig betoog, dat, met een budget van eenige honderde guldens 's jaars, het met den besten wil niet mogelijk is bij den aankoop van werken zelfs aan matige eischen te voldoen. In het belang der beide boekerijen heeft de Bibliothecaris dan ook ingrij-

1 Bijlage II. 
pende voorstellen aanhangig gemaakt, die eerlang een punt van ernstige overweging zullen uitmaken zoowel van het Bestuur onzer Instelling als van dat van het Indisch Genootschap.

Van den uitslag dier overwegingen zal het afhangen, of reeds in den loop van dit dienstjaar al dan niet een aanvang zal worden gemaakt met den druk van den Catalogus, hetzij van onze Bibliotheek alleen, hetzij in vereeniging met den inventaris van de verzameling onzer Zusterinstelling.

In afwachting daarvan is het evenwel voor het Bestuur en voor den Bibliothecaris in het bijzonder een aangename plicht te dezer gelegenheid de gevoelens onzer erkentelijkheid uit te spreken voor de vele en belangrijke geschenken, welke onze Bibliotheek telkens van verschillende zijden mocht ontvangen. Een woord van dankbare waardeering vooral aan het Departement van Koloniën en aan de Indische Regeering voor de geregelde toezending van de regeeringsuitgaven en van andere in Indië verschijnende gedrukten, waarbij ook de krachtige en welwillende medewerking van onze Commissarissen te Batavia op hoogen prijs mag worden gesteld. Een woord van dank aan onzen Ondervoorzitter, Van Deventer, voor de handschriftenverzameling, welke hij ons afstond en waarvan uitvoerige opgave is gedaan in de Bestuursvergadering van 15 Mei en Juni 1886, terwijl wij in onze jongste Bestuursvergadering zeer verrast werden met een welkom geschenk van onzen medebestuurder Dr. C. Snouck Hurgronje, die ons een groot aantal photografieën, gedurende zijne reis naar Djidda verzameld, aan onze Bibliotheek ten geschenke afstond. Ook ons medelid Dr. D. R. Capriles, te Curaçao, heeft aanspraak op onze erkentelijkheid voor de welwillende toezending van tal van werken en bladen over Curaçao en onderhoorigheden, waardoor onze boekenschat over onze Koloniën in de Antillen zeer is verrijkt geworden. Doch wij zouden te veel van Uwe aandacht moeten vergen, zoo wij al de namen wilden opgeven van hen, die onze Bibliotheek met geschenken hebben willen verrijken; wij meenen $U$ te mogen verwijzen deels naar de Notulen onzer bestuursvergaderingen, deels naar de aangelegde registers, die de Bibliothecaris, desgevraagd, gaarne aan belangstellenden ter inzage zal aanbieden.

Mocht het Instituut met betrekking tot zijne boek- en handschriftenverzamelingen en bij het wetenschappelijk verkeer met andere instellingen en personen bij voortduring vele blijken van welwillende medewerking ondervinden, het Bestuur stelt evenzeer den steun op 
hoogen prijs, welke hem in het afgeloopen jaar werd aangeboden bij de uitgave van ons tijdschrift en van andere afzonderlijke werken, alsmede ook ter aanmoediging en belooning van verdienstelijke ondernemingen,

De uitgave der "Bijdragen", welke in het vorige jaar voor het eerst in driemaandelijksche termijnen geschiedde, kon geregeld plaats hebben. Vier afleveringen, welke het eerste deel der vijfde volgreeks vormden, zagen het licht, waarin het, dank zij veler medewerking, niet aan verscheidenheid ontbreekt. Bereids is ook de le aflevering van het tweede deel, voor dit jaar bestemd, in Januari aan U verzonden, terwijl voor de volgende stukken een genoegzame voorraad kopij deels reeds ter onzer beschikking is gesteld, deels toegezegd. Ons correspondeerend lid, Dr. P. A. Tiele, zond ons reeds het vervolg zijner belangrijke studiën over de Europeëers in den Maleischen Archipel, terwijl de Leidschẻ Archivaris, mr. C. M. Dozy ons eene biographie heeft aangeboden van den ontdekker van Australië, Abel Janszoon Tasman, geput uit dusver niet geraadpleegde bronnen. Leverde onze werkzame medebestuurder E. B. Kielstra eveneens eene historische bijdrage omtrent de ontwikkeling van ons gezag ter Sumatra's Westkust, meerendeels geput uit de bij het Departement van Koloniën aanwezige archiefstukken, het is zijne bedoeling zich niet enkel te bepalen tot het eerste tijdperk van den Padrie-oorlog (1819-1825), doch ons ook uit diezelfde bronnen de geschiedenis ná 1825 te beschrijven. Nevens deze historische opstellen zult Gij weldra ook kennis kunnen nemen van het tweede gedeelte en slot der zoo aantrekkelijke studiën van den hoogleeraar Dr. G. A. Wilken over de plechtigheden en gebruiken bij verlovingen en huwelijken bij de volken van den Indischen Archipel. Van nu wijlen den volijverigen officier der Infanterie bij het Indisch leger, C. F. H. Campen, ontvingen wij eene beschrijving van de Westkust van het Noorder-schiereiland van Halémahéra met eene kaart; ons medelid Graafland, te Tandjong Pinang, zond ons eene schets van de Chineesche vestigingen in de afdeeling Karimon, terwijl de adsistentresident van Koetei, met verlof hier te lande, de heer S. W. Tromp, ons meerdere bijdragen heeft toegezegd dan de mededeelingen omtrent de Boegineezen van Koetei, die Gij van zijne hand in de laatst verschenen aflevering van ons tijdschrift hebt kunnen aantreffen.

Gij ziet, M. H., aan stof voor ons driemaandelijksch tijdschrift ontbreekt het ons niet, terwijl de Redactie hierbij gaarne aanteekent daí zij, zoodra zij bijdragen van kleineren omvang noodig mocht 
hebben, nimmer te vergeefs een beroep zal behoeven te doen op enkelen uit den Bestuurskring.

Vraagt Gij, of wij in het afgeloopen jaar, namen\$ ons tijdschrift, geene afzonderlijke werken hebben uitgegeven, ons antwoord luidt ontkennend. Het vooruitzicht bestaat evenwel, dat dit jaar in dat opzicht vruchtbaarder zal zijn. Immers, het omvangrijke werk des heeren Snouck Hurgronje, bevattende de resultaten zijner door ons gesubsidiëerde reis naar Arabië, is der volooiing nabij. Wij stellen ons voor het in twee deelen, met platen verrijkt, uit te geven, waarvan het eerste zeker tegen den aanstaanden zomer de pers zal verlaten. De uitgave geschiedt met welwillende ondersteuning van het Departement van Koloniën, dat bij Koninklijk besluit van 1 Sept. 11. no. 23 de vereischte machtiging heeft verkregen om van Regeeringswege op honderd exemplaren van het werk in te teekenen.

Ondanks deze regeeringssubsidie zijn echter de kosten, aan de uitgave van dit werk verbonden, zoo aanzienlijk, dat, wilden wij ze althans eenigermate bestrijden, van den regel moeten worden afgeweken het kosteloos aan de leden te verstrekken. Ten einde aan het werk een grooter debiet te verzekeren, zult Gij straks in de gelegenheid worden gesteld, ingevolge de voorschriften van het Reglement, ons machtiging te verleenen het ten behoeve der leden, die het mochten verlangen, voor de helft van den prijs verkrijgbaar te stellen.

Onze verwachting dat het tweede gedeelte en slot van het U bekende bekende werk van Bock's reize van Bandjermasin naar Koetei in het afgeloopen jaar eindelijk voor de pers zou zijn gereed gemaakt, is helaas! weder niet verwezentlijkt. Gedurende een groot deel van het vorige jaar was nu wijlen onze medebestuurder Robidé van der Aa door ongesteldheid verhinderd daaraan alsnog de hand te leggen. Ernstige pogingen, door ons in het werk gesteld, om ons medelid van de vervulling der door hem zoo welwillende aanvaarde taak te ontheffen, leden schipbreuk, daar hij het stellige voornemen uitsprak, om, zoodra zijne gezondheid dit slechts toeliet, den arbeid weder te hervatten en ook ten einde te brengen. Ons medelid heeft woord gehouden; juist twee dagen vó́r zijn overlijden verraste hij den Secretaris met de toezending van zijn arbeid. Helaas! dat het zijn laatste werk moest zijn, waarmede hij, eer hij van ons ging scheiden, het Instituut opnieuw aan zich heeft willen verplichten.

Terwijl een zestal vellen van het tweede gedeelte van Bock's arbeid 
bereids zijn afgedrukt, hopen wij ook eerlang het slot aan de pers te kunnen toevertrouwen, terwijl door ons in overweging zal moeten worden genomen, of de door nu wijlen den heer Robidé van der Aa eveneens toegezegde historische inleiding over Koetei en de betrekkingen van dit leenrijk tot de regeering van Nederlandsch-Indië zal achterwege blijven, dan wel door ons zal worden bezorgd; in elk geval houden wij ons overtuigd, dat wij bij den door ons nog te verrichten arbeid op de welwillende hulp van den hier te lande met verlof aanwezigen adsistent-resident van Koetei, S. W. Tromp, te zullen kunnen rekenen.

Gaarne hadden wij ook gewenscht $U$ de mededeeling te kunnen doen, dat wij, nevens den arbeid van Dr. Snouck Hurgronje, de uitgave van een ander niet minder gewichtig werd hadden voorbereid. Het is $\mathrm{U}$ bekend, dat door den belangeloozen ijver van het Nederlandsch Bijbelgenootschap, te Amsterdam, in 1864 het eerste deel werd uitgegeven van de door Dr. B. F. Matthes bewerkte, uit oorspronkelijke Boegineesche stukken bestaande Chrestomathie, waardoor èn aan de wetenschap èn aan de waarachtige ontwikkeling van den Inlander op Zuid-Celebes een niet genoeg te waardeeren dienst werd bewezen. $\mathrm{Nu}$ de oplaag van dit werk op weinige exemplaren na geheel uitgeput is en het Nederlandsch Bijbelgenootschap de zorg voor de uitgave van literarische werken aan anderen moet overlaten, werd ons het voorstel gedaan vanwege het Instituut eene nieuwe uitgave van meergemeld eerste deel te doen bezorgen : - eene uitgave, die tevens èn wat vorm èn wat inhoud betreft, eene veranderde en vermeerderde zou zijn, en waarbij dr. Matthes ons de vriendelijke toezegging deed geheel belangeloos zijne hulp te zullen verleenen.

Met hooge waardeering zoowel van den te verrichten arbeid als van het edel aanbod, dat ons geacht medelid vereert, heeft het Bestuur besloten gevolg te geven aan het gedane voorstel, mits echter de Regeering hare krachtige medewerking daaraan niet zou onthouden. Een verzoek dezerzijds tot den Minister van Koloniën gericht, om ons door toekenning eener subsidie de voorgenomen uitgave mogelijk te maken, mocht echter geene gunstige beschikking erlangen. Eerbiedigen wij dit besluit, het is ons tevens eene voldoening uit 's Ministers schrijven te mogen ontwaren, dat het in de bedoeling ligt, om, zoodra het blijkt dat de oplaag van het werk werkelijk geheel uitgeput is en er aan een herdruk daarvan behoefte bestaat, dien geheel voor 'slands rekening te doen bezorgen.

Moge die tijd niet nog in een ver verschiet liggen, doch het aan 
onzen Matthes alsnog vergund zijn zelf voor de hernieuwde uitgave van zijn werk zorg te kunnen dragen, waardoor èn de belangen der inlandsche bevolking van Zuid-Celebes èn de beoefening van de Boegineesche taal- en letteren door de aldaar vanwege het Gouvernement geplaatste en nog te plaatsen en hier te lande zoowel als in Indië te vormen ambtenaren zullen worden bevorderd!

Nog andere voorstellen werden er aan onze overweging aanbevolen. De wensch werd uitgesproken, doch niet vervuld om vanwege het Instituut de uitgave te doen geschieden of te bevorderen van een omvangrijken arbeid van onzen oud-Penningmeester Corns. de Groot betreffende Blitong. Een aantal Maleische handschriften werden ons door den heer von Faber aangeboden, doch de uitgave daarvan werd ons ontraden. Nog kwam men tot ons met het voorstel om onze ondersteuning te verleenen aan eene nederlandsche bewerking van het Spaansche werk van D. José Montero y Vidal, getiteld: "El Archipiélago Filipino y las Islas Marianas, Carolinas y Palaos, su Historia, Geografia y Estadistica". Hieromtrent zoowel als over de beide andere genoemde onderwerpen meenen wij te kunnen volstaan met $U$ naar de Notulen onzer Bestuursvergaderingen te verwijzen, waarin een en ander uitvoerig behandeld is.

Eveneens is dit het geval met betrekking tot onze pogingen om eene wetenschappelijke zending naar Hadramaut te bevorderen; tot de ons gedane voorstellen, strekkende tot bewaring en onderhoud der Hindoe-monumenten op Java; alsmede tot het verleenen van eene subsidie voor de wetenschappelijke onderzoekingen van ons medelid Dr. J. J. M. de Groot in China.

Deze drie laatste onderwerpen behooren echter nog niet tot de geschiedenis: zij maken nog een punt van ernstig onderzoek uit. Een volgend Verslag moge $U$ de uitkomsten onzer overwegingen mededeelen.

En hiermede, M. H., is onze taak ten einde. Mocht Gij uit onze mededeelingen de overtuiging hebben verkregen dat het afgeloopen jaar niet als een onvruchtbaar tijdperk in de annalen onzer Instelling kan worden geboekt, laat het voorts bij voortduring ons streven zijn, met inspanning van al onze krachten, hare belangen te bevorderen!

DEN HAAG, Februari 1887.
De Secretaris, Dr. Th. CH. L. WiJnmalfn. 
BiJlage I.

\title{
NAAMLIJST DER LEDEN
}

\author{
VAN HET
}

INSTITUUT.

(MAART 1887.)

\begin{abstract}
$\rightarrow+90630 .-$
Het getal contribueerende Leden bedraagt 438, waarvan in Nederland en Indië 8 Donateurs, 5 contribueerende instellingen, en 281 gewone Leden, en in de overzeesche bezittingen en koloniën 144 gewone Leden. Met 114 wetenschappelijke instellingen en vereenigingen staat het Instituut in betrekking en telt 1 Eerelid, 5 correspondeerende Leden en 31 buitenlandsche Leden.
\end{abstract}

\section{BESCHERMHEER :}

\section{Z. M. D E K $\mathbf{~} \mathbf{I} \mathbf{N}$.}

\section{BESTUUR:}

Jaar van aftreding

Mr. w. Ridder van RAPPaRd, Voorzitter . . . . . . . . 1889

J. H. DE GROOT, Penningmeester . . . . . . . . . . 1888

Dr. т. c. L. wiJnMalen, Secretaris . . . . . . . . . . . 1888

Prof. Dr. G. SCHLEger . . . . . . . . . . . . . . . 1888

Dr. J. G. F. RIEDEL . . . . . . . . . . . . . . . . 1889

н. с. HUMMe . . . . . . . . . . . . . . . . . . 1889

E. B. KIELSTRA . . . . . . . . . . . . . . . . . . 1890

Dr. c. SNOUCK HURGRONJE . . . . . . . . . . . . . . 1890

Prof. G. K. NIEMANN . . . . . . . . . . . . . . . 1890

Н. Ј. воОІ . . . . . . . . . . . . . . . 1891

Prof. Dr. H. KERN . . . . . . . . . . . . . . . . 1891

Prof. Dr. K. MARTIN . . . . . . . . . . . . . 1891 


\section{BUITENLANDSCHE LEDEN.}

Z. H. Prins Roland Bonaparte, Saint-Cloud.

$\triangle B B E ́$ P. FAVRE, Parijs.

Dr. A. ReINHoLd Rost (India Office

Library), Londen.

w. W. HUNTER, Calcutta.

Prof. angelo de gubernatis, Florence. T. J. hovell thurlow, Londen.

Prof. Dr. albrecht weber, Berlijn. ALFRED VON KREMER, Weenen. Prof. H. L. FLeIscher, Leipzig. Sir Walter elliot, Wolfelce (Schotland.) Prof. emilio teza, Piza.

gUIDO CORA, Turijn.

Sir henRy sUMNer maine, Londen.

Colonel H. YULE, Londeu.

Dr. PRIEDRICH MÜLLER, Weenen.

Prof. GeORg gerland, Strassburg i/E.

Graaf G. H. J. Meiners D'estrey, Parijs,

6 Quai du Marché Neuf.

Mrs. De Croizier, Parijs, 9 Rue du quatre

Septembre.
Radja sourindro moHUn tagore, Mus. Doc., Calcutta.

N. DE Miklouho maclay, Australia. Sidney, Biological station at Watson's Bay near Sydney N. S. W.

Dr. A. B. MEIJER, Dresden.

G. DORIA, Genua.

ARISTIDE MARre, Parijs (11 rue Brey, près de l'Arc de l'Etoile.)

Prof. Dr. G. von DER Gabelentz, Leipzig. Prof. Dr. E. H. GIGLIOLI, Florence. PANDIT BHAGWâNLâL INDRAJI, Bombay. Prof. Dr. A. Bastian, Berlijn.

Prof. Dr. R. BRAndstetter, Lucern.

Prof. Dr. Jos. конLer, Wurzburg.

Jules silvestre, Rochefort sur ner, 2 Rue des Fonderies (Charente inférieure) Frankrijk.

Prof. FERD. BLUMENTRITT, Leitmeritz

(Bohemen.)

\section{NE D E R L A N D.}

\section{DONATEURS.}

De Nederlandsche Handelmaatschappij. I. D. pRANSEN van DE PUTte, 's Hage. Mr. H. J. VAN BUREN, Rotterdam. Mr. A. J. DUYMaER van twist, Deventer. Mr. w. Baron van goltstein, 's Hage. Dr. a. vrolik, Arnhem. F. 's JАСOB, Utrecht.

\section{EERELEDEN.}

Prof. Dr. P. J. veth, Arnhem.

\section{CONTRIBUEERENDE INSTELLINGEN.}

De Bibliotheek van de Universiteit van Amsterdam.

Het Nederlandsch Bijbelgenootschap, te Amsterdam.

Het Nederlandsch Zendelinggenootschap, te Rotterdam.

Het Rijks Ethnographisch Museum te Leiden.

Vereeniging Pomona, te Menado. 
GEWONE LEDEN.

Dr. A. T. VAN $\triangle \mathrm{KEN}$, 's Gravenhage. D. AITton, 's Gravenhage.

J. E. ALBRECHT, 's Gravenhage. Jhr. D. F. vaN ALPHEN, Haarlem. Jhr. E. T. M. VAN ALPHEN, 's Gravenhage. J. ARNTZ, Culemborg.

J. H. VAN BALEN, Voorburg.

A. H. L. BADINGS, Harderwijk.

Mr. с. BAKE, 's Gravenhage.

Mr. J. в. BANCK, 's Gravenhage.

Mr. W. H. DE BEAUFORT, Leusden.

Prof. Mr. a. BEAUJon, Amsterdam.

Mr. G. Belinfante, 's Gravenhage.

Jhr. Mr. c. J. van beresteiJn, Rijswijk.

Mr. w. B. Bergsma, Apeldoorn.

p. BEIJERINCK, Leiden.

A. A. BIENFatt, Amsterdam.

Mr. A. J. E. A. BIK, Amsterdam.

G. BIRNIE, Deventer.

Dr. н. BLINK, Amsterdam.

J. c. BLOEM, 's Gravenhage.

P. A. M. Boele vaN Hensbroek, 's Hage.

J. BoissevaIN, Amsterdam.

в. в. BONN, 's Gravenhage.

н. Ј. вооL, Leiden.

P. R. BOs, Groningen.

J. $\boldsymbol{x}$. R. S. VAN DEN BOSSCHE, 's Hage.

c. Bosscher, 's Hage.

H. G. BOUMEester ,'s Gravenhage.

Mr. L. DE FILLIETtaz bousquet, 's Hage.

Mr. w. à BRAKEL REIGER, 's Hage. w. G. Bon BRANTSEN vAN DE ZIJP, 's Hage. Jhr. Mr. W. M. DE BRAUW, Middelburg. J. A. VAN DEN BROEK, Delft. W. D. J. BROUWER, Zwolle.

G. BRUNNer, Amsterdam.

A. WerUMEUS bUNing, Rotterdam.

Dr. c. I. VAN DER BURG, Leiden.

J. H, DE BUSsY, Amsterdam. 5e Volgr. II.
P. J. BUYSKES, 's Gravenhage

Mr. c. в. J. Graaf vaN BYLANDT, 's Hage.

Dr. w. G. c. BYVANCK, Leiden.

H. D. CANNE, 's Gravenhage.

Prof. Dr. D. Chantepie de la saussaye, Amsterdam.

P. N. VAN DER CHIJS, Djeddah.

A. N. CLAVIER, Leiden.

J. L. ClutJssenaer, Utrecht.

w. A. COBLIJN, Nijmegen.

Mr. F. B. CONINCK LIEFsting, 's Hage.

w. COOL, Breda.

Prof. Mr. P. W. A. CORT VAN DER LINDEN, Groningen.

Mr. J. COUPERUS, 's Gravenhage.

J. T. CREMER, Haarlem.

Mr. E. J. J. B. CREMERS, 's Gravenhage.

G. C. DAUM, 's Gravenhage.

Mr. w. K. Baron vaN DEDEM, Hoorn.

J. J. DERMOUT, Scheveningen.

s. VAN DEVEnter, 's Gravenhage.

J. S. A. van DISSEL, Delft.

Dr. G. J. DOZY, Noordwijk Binnen.

Dr. F A. C. DUMONTIER, 's Gravenhage.

J. DIJK wz., 's Gravenhage.

R. VAN ECK, Breda.

c. A. ECKSTEIN, 's Gravenhage.

c. P. VAN EEGHEN, Amsterdam,

Jhr. Mr. W. c. A. ELOUT VAN SOETERwOUdE, 's Hage, (tijdelijk in Indië).

Mr. A. J. VAN EMDEN, 's Gravenhage.

Mr. J. C. VAN EIJK, Amsterdam.

Jhr. Mr. F. I. J. VAN EYSINGA,

Leeuwarden.

IJ. FeEnstra, Amsterdam.

J. H. FERGUSON, 's Gravenhage.

G. J. PLEET, Utrecht.

P. FRAISSINet, Amsterdam.

F. G. GEERLING, 's Gravenhage. 
A. J. DE GELDER, Delft.

J. W. JäGER, 's Gravenhage.

Dr. J. H. F. SOLLEWIJN GELPKe, 's Hage. P. W. JANSEN, Amsterdam.

Mr. J. VAN GENNEP, Rotterdam.

W. L. A. GERICKE, 's Gravenhage.

c. A. J. L. JEEKEL, Huize Kleinhorst, Loenen (Veluwe).

Jhr. Mr. W. T. GEVERS DEYNOOT Jr.,

's Gravenhage.

Mr. F. H. GöBEL, 's Gravenhage.

Prof. Dr. M. J. DE GOEJe, Leiden.

Mr. H. M. A. Bon VAN DER GOES VAN DIRXLAND, 's Gravenhage.

Prof. J. R. P. F. GONGGRIJP, Delft.

Mr. G. J. GRASHUIS, Leiden.

D. GRIVEL, 's Gravenhage.

CORN'. DE GROOT, 's Gravenhage.

J. H. DE GROOT, 's Gravenhage.

Mr. H. F. L. hamelberg, Arnhem.

Mr. G. G. van HARENCARSPEL, 's Hage.

L. K. HARMSEN, Leiden.

G. J. HARREBOMÉE, 's Gravenhage.

D. HARTEVELT, Leiden.

J. P. c. HARTEVELt, 's Gravenhage.

Jhr. c. Hartsen, Amsterdam.

J. J. hasselman, Tiel.

w. van hasselt, Amsterdam.

Mr. J. HEEMSKerk AZ., 's Gravenhage.

Mr. A. HeEMSKerk AZ., Amsterdam.

B. HELDRING, Amsterdam.

Mr. J. E. HENNY, Amsterdam.

J. K. VAN DER HEIJDEN, 's Gravenhage.

F. HEIJNEN, 's Gravenhage.

н. HIEBINK, Zutfen.

I. J. H. GIJSBERTI HODENPIJL, Haurlem.

A. C. HOogeveen, 's Gravenhage.

Jhr. H. w. т. HoRA siccama, 's Hage.

Dr. м. тн. ноuтsмa, Leiden.

J. HUDIG DZ., Amsterdam.

н. с. HUMME, 's Gravenhage.

Jhr. Mr. J. HUYDECOPER VAN MAARSSEveEN, Maarsseveen

P. c. HUIJSER, 's Gravenhage.

H. A. INSINGER, Vuursche.

Mr. е. н. 's Јасов, Utrecht.

Dr. F. A. JENTINK, Leiden.

Mr. D. Josephus Jitta, Amsterdam.

A. C. Joosten, Amsterdam.

Prof. Dr. c. M. KAN, Amsterdam.

A. J. H. VAN KAPPEN, 's Gravenhage.

Jhr. Mr. A. P. c. KARNebeEk, 's Hage.

Prof. Dr. H. KERN, Leiden.

C. E. vaN Kesteren, Brussel.

E. B. KIELSTRA, 's Gravenhage.

w. F. VAN ERP TAALMAN KIP, 's Hage.

H. C. KLINKERT, Leiden.

Mr. TH. A. KLINKHAMER, 's Gravenhage.

J. H. P. E. KNIPHORST, 's Gravenhage.

Jhr. W. H. W. DE KосK, 's Gravenhage.

J. C. DE KOCK VAN LEEUWEN, 's Hage,

L. CH. KRUIJPF, 's Gravenhage.

Prof. Dr. E. F. KRUIJPF, Groningen.

J. A. KRUIJT, Pinang.

J. D. KRUSEMAN, 's Gravenhage.

J. KUYPER HZN., 's Gravenhage.

K. ғ. H. VAN LANGEN, 's Gravenhage.

N. D. LAMmers vaN TOOREnbURG, 's Hage.

Mr. J. W. vaN LANSBERGE, Brummen.

Mr. H. o. VAN DER LINDEN, Dordrecht.

C. J. LEENDERTZ, Leiden.

W. H. VAN LEEUWEN, Amsterdam.

A. VAN LEeUWEN, 's Gravenhage.

Mr. H. D. Levyssohn norman, 's Hage.

J. H. LiefTincK, Amsterdam.

Mr. JAC. LION, 's Gravenhage.

Mr. o. J. H. Graaf vaN LIMBBURg STIRUM, 's Gravenhage.

Prof. Mr. P. A. VAN DER LITH, Leiden.

Prof. Mr. J. DE LOUTER, Utrecht.

D. F. W. LUCASSEN, 's Gravenhage.

Mr. R. MaCALESTER LOUP, 's Gravenhage.

Mr. J. C. DE MAREZ OYENS, 's Gravenhage.

Prof. Dr. K. Martin, Leiden. 
Dr. B. F. Matthes, 's Gravenhage. Mr. F. ALTING MEES, 's Gravenhage. AUGUST MESRITZ, Amsterdam.

G. A. P. MOLENGRAAFF, Utrecht.

Dr. K. w. M. Montis, Schiedam.

H. MULLER SZN, Rotterdam.

Mr. a. VAN NAAMEN VAN EEMNES,

's Gravenhage.

J. J. NAEFF, 's Gravenhage.

Mr. s. H. NEDERBURGH, 's Gravenhage. J. R. H. NEERVOORT VAN DE POLL,

Amsterdam.

Mr. H. A. A. NEYs, 's Gravenhage.

A. D. VAN DER GON NE'TSCHER, 's Hage. P. M. NETSCHER, 's Gravenhage.

Prof. G. K. niemann, Delft.

Jhr. Mr. o. E. vin NISPEN, 's Hage.

M. NIJHOFF, 's Gravenhage.

Mr. o. W. star nUMaN, 's Gravenhage.

A. P. M. VAN OORDT, Leiden.

H. J. Oosting, Assen.

G. OOSTERgetel, 's Gravenhage.

Mr. J. B. van osenbruggen, 's Hage. c. P. PABST, 's Gravenhage.

W. PAHUD DE MORTANGES, Brummen.

Mr. J. G. PATij́, 's Gravenhage.

Mr. D. L. F. DE PAULY, 's Gravenhage.

M. P. PELS, Amsterdam.

M. T. H. PERELAER, 's Gravenhage.

Prof. Mr. N. G. PIERson, Amsterdam.

Prof. Dr. J. PIJNAPPEL GZN., Leiden.

Mr. M. J. PIJNAPPEL, Amsterdam.

J. G. PLAte $J_{R}$, Leiden.

c. W. PLEYTe WzN., Leiden.

w. PLeyte, Leiden.

A. POMPE, Breda.

H. PRANGe, Utrecht.

TH. PRIJZE, 's Gravenhage.

a. S. fransen van de pUtte, Árnhem.

Prof. Mr. H. P. G. QUACK, Amsterdam.

Jhr. Mr. J. K. W. QUARLES VAN UFFORD, 's Gravenhage.
Jhr. W. VAN RADERS, 's Gravenhage.

Mr. w. Ridder vaN RAPPARD, 's Hage.

M. A. VAN RHEDE VAN DÉR KLOOT,

's Gravenhage.

Jhr. Mr. G. c. J. van REenen, 's Hage.

Mr. W. J. vaN WELDEREN Baron RENGERS, Leeuwarden.

G. C. KLERK DE REUS, 's Gravenhage.

Dr. J. G. F. RIEDEL, Utrecht.

Dr. w. N. DU RIEU, Leiden.

J. G. ROBBERs, Rotterdam.

Jhr. Mr. w. r. Rochussen, 's Gravenhage.

Jhr. Mr. J. ROËLL, 's Gravenhage.

G. Baron rosenthal, Amsterdam.

J. W. Roskes, Rotterdam.

c. RUEB cZ, Rotterdam.

Dr. E. VAN RIJCKEVORSEL, Rotterdam.

A. W. J. PARNCOMBE SANDERS, 's Hage.

Mr. J. c. J. VAN DER SCHALK, Noordwijk.

Binnen.

P. H. VAN SCHERMBEEK, Utrecht.

Mr. w. A. A. J. Bon SCHIMMELPENNINCK VAN DER OIJE VAN DE POLL, 's Gravenhage. Prof. Dr. G. schlEGEL, Leiden.

J. $\boldsymbol{F}$. L. SCenneider, Delft.

Dr. J. SEMMeLINK, 's Gravenhage.

A. M. servatius, Terwolde bij Deventer.

Mr. c. J. sIckesz, Laren.

Jhr. J. D. sIx, 's Gravenhage.

Mr. L. A. J. W. Baron SLOET VAN DE BEELE, Arnhem.

R. A. W. SLUITER, 's Gravenhage.

Dr. H. SMEDING, Haarlem.

Mr. P. J. SMEELE, 's Gravenhage.

н. јон. SMID, Dennenoord, Laren.

L. w. тн. SсHмшт, Leiden.

J. c. J. surts, Bronbeek bij Arnhem.

JoH. F. SNELLEMAN, Rotterdam.

Dr. C. SNOUCK HURGRONJE, Leiden.

Prof. J. SPANJAARD; Delft.

Dr. J. s. SPEIJER, Amsterdam.

Mr. J. P. SPRENGER VAN EIJK, 's Hage. 
c. M. F. STOCKHAUSEN, Utrecht.

W. P. VAN STOCKUM JR., 's Gravenhage.

Dr. N. P. VAN DER sTOK, Rijswijk.

(Buitengedachten).

F. DE STOPPELAaR, Leiden.

Mr. w. sTORTENBEKER Jr., 's Gravenhage.

Jhr. Mr. v. DE stuers, 's Gravenhage.

Jhr. Mr. J. E. DE sturler, 's Hage.

Prof. Dr. W. F. G. SURINGaR, Leiden.

A. W. SIJTHofr, Leiden.

Mr. J. P. R. TAK VAN POORTVLIET,

's Hage.

P. E. Tegelberg, Amsterdam.

Prof. Dr. c. P. TIELE, Leiden.

Mr. G. VAN TIENHoven, Amsterdam.

Dr. M. TREUB, Voorschoten.

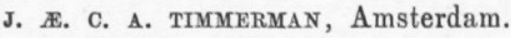

P. F. LAGING tobIAS, Nijmegen.

N. trakranen, Amsterdam.

F. c. TROMP, 's Gravenhage.

s. w. TROMP, 's Gravenhage.

Mr. F. c. valck, Gravenhage.

Prof. Dr. J. J. P. vaLETON, Amersfoort.

Mr. s. A. VENING MEINEsz, Rotterdam.

Mr. J. A. DE vICQ, Djeddah.

T. P. VIRULY, Leiden.

Mr. D. VISSER VAN HAZERSWOUDE, Amsterdam.

c. A. M. VAN VLIET, 's Gravenhage.
Dr. J. VAN DER vLIET, Haarlem. B. R. F. VAN vLIJMEN, Nijmegen. JOOST vaN volLenhoven, Rotterdam. Mr. J. A. G. Baron DE vos VAN STEENWIJK, Brummen.

Prof. A. c. VREEDE, Leiden.

E. DE WAAL, 's Gravenhage.

w. A. VAN WALCHEREN, 's Gravenhage. M. J. WALLER, Amsterdam.

Dr. s. J. WARREN, Dordrecht.

A. E. WASZKLEWICZ, 's Gravenhage.

A. W. P. WeITZEL, 's Gravenhage.

Mr. a. C. Wesenhagen, Rotterdam.

G. F. Westerman, Amsterdam.

F. W. WESTEROUEN VAN MEETEREN, Amsterdam.

c. F. W. WICHERS VAN KERCHEM, Leiden. WILLEM WIJT, Rotterdam.

Prof. Dr. G. A. WLLKEN, Leiden.

J. WOLBERs, Utrecht.

w. P. Wolterbeek, Amsterdam.

J. wüste, Amsterdam.

Jhr. Mr. H. C. VAN DER WIJCK, 's Hage.

Jhr. Mr. H. VAN DER WIJCK, 's Hage.

Dr. тH. CH. L. wiJnMalen, 's Hage.

JоН. ІлкЕмА, 's Gravenhage.

J. W. IJZERMAN, 's Gravenhage.

s. B. Zeverijn, Amsterdam.

\section{CORRESPONDEERENDE LEDEN.}

c. H. B. VON ROSENBERG, 's Gravenhage.

Dr. P. A. TIELE, Utrecht.

J. C. NEURDENBURG, Rotterdam.

J. D. в. SchMrettz, Leiden.

M. L. van Deventer, Prinsenhage, bij Breda. 


\section{NEDERLANDSCH OOST- EN WEST-INDIË.}

Be Biauw Troan, Majoor titulair der Chineezen, te Samarang. (Donateur.)

\section{GEWONE LEDEN.}

J. W. H. ADÈR, Predikant te Batavia.

J. A. AECKERLin, Secretaris van de residentie Benkoelen (Sumatra).

B. VAN BAAK, Resident van Djokjakarta.

H. P. A. BAKKER, Controleur le klasse te Mandor $\mathrm{W}^{\mathrm{r}}$ afdg. van Borneo.

c. BAUMGaRten, te Tjikoppô, Buitenzorg.

Mr. G. J. A. VAN BERCKEL, Voorzitter van den landraad te Neira (Banda).

Mr. N. P. VAN DEN Berg, President van de Javasche Bank, Batavia.

Mr. L. w. C. VAN DEN BERG, Ambtenaar voor de Inlandsche talen, Batavia.

Ј. BODDÉ, Hulpprediker te Tengah Sonder, Menado.

н. w. вosman, Tweede onderwijzer aan de kweekschool te Probolinggo.

D. F. vAN BRAAM MORRIS, Gouverneur van Celebes en onderhoorigheden, te Macassar.

Dr. J. L. A. BRANDEs, Ambtenaar voor de Inlandsche talen, Batavia.

Dr. н. BReitenstein, Officier van gezondheid, te Atjeh.

J. A. H. bReijmann, Controleur le klasse in de afd. Moesi Ilir (Sekajoe) res. Palembang.

R. BRoNS MIDDEL, Hoofdonderwijzer te Depok.

M. BUYs, laatst Predikant te Padang, te Batavia.

Dr. DAVID R. CAFriues, Geneesheer te Curaçao.

w. F. van charante, President van het Liefdadigheids-gesticht enz. te Depok (Buitenzorg).

Mr. J. A. VAN DER CHIJS, Ambtenaar belast met het toezicht over 't archief, Batavia.

Dr. II. DE COCK, Arts en officier van Gezondheid te Kajoe Tamam (Sumatra's Westkust.)

Mr. J. w. тH. COHen stuart, Advocaat, Samarang.

A. J. w. van DELden, Chef van de firma Reynst \& Vinju, Batavia.

K. F. VAN DELDEN-LAËRNe, Adsistent-resident van Kraksaän, Probolinggo.

J. A. DEZentJe, Landhuurder, Ampal, residentie Soerakarta.

s. vAN DISSEL, Inspecteur van het Inlandsch onderwijs, Batavia.

E. DOUWES DEKKER, Directeur van de N. I. Levens-verzekering maatschappij te Batavia.

P. A. L. E. VAN DIJK, Controleur le klasse te Silindoeng afd. Siboga, res. Tapanoeli.

Dr. A. VAN DER ELST, Officier van gezondheid, te Malang.

Mr. w. A, engebbrecht, President van den Raad van justitie, Samarang. 
H. E. D. engelHaRd, Controleur le klasse, in de onderafd. Lematang Ilir (Moeara Enim), res. Palembang.

J. ENNEN, Tweede onderwijzer aan de kweekschool, Fort de Kock.

Mr. J. W. ESSERs, Raadsheer in het Hooggerechtshof, Batavia.

r. FOCKens JR., Controleur 2e klasse, Krawang.

W. VAN GELDER, Hoofdonderwijzer aan de kweeksehool te Bandoeng.

D. GERTH VAN WIJK, Leeraar in de Maleische taal, Commissaris van het Instituut, Batavia.

G. P. H. H. GONGGRIJP, Algemeen ontvanger, Batavia.

W. P. GRoeneveldt, Secretaris van het Dep. onderwijs enz., Batavia.

N. GRAAFLAND, Adjunct-inspecteur van het Inlandsch onderwijs, Ambon.

A. F. P. GRAafland, Aspirant-controleur te Tandjong Pinang, Riouw.

Dr. J. J. M. DE GROOT, Tolk voor de Chineesche taal, tijdelijk in China (Amoij).

Dr. J. G. H. GUNNING, Ambtenaar voor de Inlandsche talen, tijdelijk belast met geven van onderwijs in de Jav. taal aan het Gymn. Willem III, te Batavia.

Dr. c. Gutteling, Geneesheer, Batavia.

Mr. J. A. BAAKMAN, Redacteur Bat. Handelsblad, Batavia.

c. J. vaN HAASTERT, Tweede onderwijzer aan de kweekschool te Bandoeng.

J. HАBвEMA, Hoofdonderwijzer aan de kweekschool te Amboina.

A. HAGA, Generaal-Majoor, chef der IIde afdeeling van het Dep. van oorlog, te Batavia.

A. L. van hasselt, Secretaris van den Raad van Indië, Commissaris van het Instituut, Batavia.

o. L. Helfrich, Controleur 2e klasse, te Benkoelen.

J. HeiJTING, Hoofd-inspecteur voor de koffiecultuur, Batavia.

в. Hовтіnк, Tolk voor de Chineesche taal te Deli Médan (Sumatra's Oostkust).

G. W. W. c. Baron vaN hö̈vell, Assistent-resident van Gorontalo (Menado.)

w. c. HOOGKaMER, Assitent-resident van de Afdeeling Tonah Datar (Fort van der Capellen.)

w. новzоо, Zendeling, Samarang.

Dr. J. w. HoffManN, Geneesheer, Buitenzorg.

K. F. HOLLE, Adviseur, Waspada (Preanger Regentschappen).

Dr. D. W. Honst, laatst Controleur le klasse, te Kroë, resid. Benkoelen, thans ter beschikking van den resident van Ternate.

B. v. HoUthulJsen, Notaris, te Samarang.

Mr. A. J. IMMrNcK, Raadsheer bij het Hoog Gerechtshof, Batavia.

A. M. Jokkes, Assistent-resident te Martapoera.

Mr. Dr. J. c. G. JONKER, Ambtenaar voor de Inlandsche talen, Macassar.

Mr. т. H. DER KINDEREN, Lid van den Raad van Ned.-Indië, Batavia.

J. KNEBEL, Controleur le klasse te Tjikadang in de residentie Preanger Regentschappen. 
C. P. J. VAN KoEtSveld, Assistent-resident van Koetei (Borneo.)

c. W. F. Kooman, benoemd O. I. Ambtenaar, te Batavia.

P. J. Kooreman, Assistent-resident van Painan, Sumatra's Westkust.

G. J. vaN KOOTEN, Kapitein van den generalen staf, N. I., Pontianak.

J. Kreemer, Zendeling-leeraar, Malang (Pasoeroean).

R. c. Kroesen, Gouverneur van Sumatra's Westkust, Padang.

c. A. KRoesen, Controleur le klasse, te Bindjei Sumatra's Oostkust.

J. c. KUMMER, Adjunct-inspecteur van het Inlandsch onderwijs, Magelang.

c. H. M. LE Roux, Controleur le klasse in de Afd, Karimon, Riouw en onderh.

Dr. w. van lingen, Predikant te Pekalongan.

F. E. LUITJEs, 2e Onderwijzer aan de kweekschool voor inlandsche onderwijzers te Ambonia.

H. L. C. TE MEchelen, (titulair) Resident, Rembang.

Mr. J. H. MeIss, Griffier te Bondowoso, Besoeki.

Mr. a. W. a. vaN DER MEIJ, Griffier van den landraad te Poerwodadi, Samarang. W. MEIJER, Hoofdonderwijzer aan de school voor zonen van Inlandsche hoofden te Magelang (Kedoe.)

J. J. MEIJER, Controleur 2e klasse bij het Binnenlandsch Bestuur te Rangkasbitoeng, Afdoeling Lebak, Bantam.

J. E. DE MEIJIER, Ingenieur le kl. b/d Waterstaat en B. O. W. in N. I., Batavia.

L. J. J. мrсHrelsen, Lid in den Raad van Indië, Batavia.

TH. MOUNIER, Inspecteur voor de koffiecultuur te Batavia.

o. M. DE MUNNICK, Resident van Batavia.

c. VAN DER GON NETSCHER, Assistent-resident, te Panaroekan, Besoeki.

J. в. NEUManN, Controleur le klasse in de onderafdeeling ommelanden van Padang (Loeboeh Begaloeng), Sumatra's Westkust.)

Dr. J. c. c. W. vaN Nooten, Leeraar in de wis- en natuurkunde aan de Hoogere Burgerschool te Soerabaja.

н. A. DE Nools, Onderwijzer te Samarang.

Mr. a. NUHOUt vAN DER veEN, Referendaris bij het departement van Justitie, Batavia.

Dr. H. J. OFferhaus, Predikant te Amboina.

c. J. okHutzen, 2e Luitenant der Infanterie, te Ternate.

c. A. van opHUIJZen, Hoofdonderwijzer te Padang Sidempoean (Tapanoeli), Sumatra.

J. H. PANNEKOEK, Lid in den Raad van N.-I., Batavia.

J. PEelen, Contrôleur le klasse in de onderafdeeling Pasoemahlanden (Bandar), Residentie Palembamg.

G. w. H. PELTZER, Controleur 2e klasse in de onderafd. Moeara Laboeh, Sumatra's Westkust.

Mr. M. c. PIEPERs, Raadsheer in het Hoog-Gerechtshof, Batavia.

c. Poensen, Zendeling-leeraar, Kediri. 
Jhr. F. Fompe van MEerdervoort, Kapitein bij den gen. staf, Batavia.

H. E. PRINS, Secretaris van het Gouvernement Sumatra's Westkust, te Padang.

A. PRUYS VAN DER HOEVEn, Lid in den Raad van Nederl. Indië, Batavia. RADEN ADIPATI ARIA KOESOEMA DININGRAT, Tjiamies.

FADEN ADIPATI sosRo NEgORO, Rijksbestierder van Soerakarta.

RADEN MAS ISMANGOEN DANOE wINOTO, Adjunct-inspecteur van het Inlandsch onderwijs, Probolinggo.

RADen mas toemenggoeng pandJ adiningrat, Regent van Demak.

H. L. Janssen van RAaY, Directeur van het Departement Burgerl. Openbare Werken, Batavia.

Dr. H. M. D. VAN RIEMSDIJK, Inspecteur 'ij het Inl. onderwijs, Fort de Kock. Dr. L. W. G. DE ROo, Directeur van Financiën, Batavia.

J. F. A. DE Rools, Controleur le klasse in de onderafdeeling Poear Datar en Mahi, Padangsche Bovenlanden.

в. J. Е. возкотт, Assistent-resident van Tebing Tinggi, res. Palembang.

J. a. van rijn van alkemade, Controleur 2e klasse te Tandjong-Poera, Sumatra's Oostkust.

A. A. L. J. RoulJer, Predikant te Banda.

G. A sCHERER, Resident te Bengkalis, Oostkust van Sumatra.

K. L. van schouwenburg, Directeur Hoogere Burgerschool, Semarang.

L. $\boldsymbol{\text { . }}$. tUiJl schuitemaker, Hoofdonderwijzer, aan de kweekschool te Probolinggo.

J. H. F. schultz, Adsistent-resident van Komering, Ogan-Oeloe en Enim en de Ranau-districten, res. Palembang.

W. H. SENN VAN BASEL, Serang (Bantam).

w. ғ. sIKMaN, Resident van Benkoelen. (Sumatra.)

g. SIEBURgr, Controleur der 2e klasse te Tamiang, Sumatra's Oostkust.

A. J. SNOUCK HURGRONJE, Notaris te Soerabaja.

A. sor, Resident van Banka en onderhoorigheden, Muntok.

A. J. SPAAN, Resident van Soerakarta.

J. w. stemroort, Majoor te Kota Radja (Atjeh).

Dr. J. P. VAN DER STOK, Directeur van het Observatorium te Batavia.

J. STORMER, Controleur, te Batjan.

H. N. STUART, Tolk voor de Chineesche taal, Semarang.

E. C. BARON SWEERTS DE LANDAS WIJBORGH, Gouvernements-Secretaris, Batavia. TJOA DJIEN SING, Kapitein der Chineezen, te Soerabaja.

J. L. VAN DER TOORN, Hoofdonderwijzer, Fort de Kock (Padangsche Bovenlanden). w. L. troostenburg de BrUijn, Controleur 2e klasse te Soepajang, Sumatra's Westkust.

F. Twiss, Controleur le klasse te Natal, Res. Tapanoeli, Gouv. Sumatra's Westkust.

D. F. UHLENBEcK, Hoofdcommies ter Algemeene Secretarie, Batavia. 
Mr. A. w. c. verweis, President van den landraad, Batavia.

J. M. van vleuten, Directeur Dep. Binnenlandsch Bestuur, Batavia.

L. м. vonck, Aspirant-controleur te Tebing-Tinggi, res. Palembang.

Dr. A. G. vorDERMan, Stadsgeneesheer te Batavia.

G. DE vos, Majoor der Genie O. I. leger, te Batavia.

w. H. VRIJBURG VAN DER HELL, Aspirant-controleur, te Soekaboemi.

Mr. J. DE WAL, benoemd Rechterlijk Ambtenaar in O. I., te Batavia.

A. F. VON DE WALL, Batavia.

c. w. J. WenNeker, Pastoor, Soerabaja.

Mr. W. A. P. F. L. WINCKEL, Rechterlijk Ambtenaar te Batavia.

J. A. B. WISELIUS, te Magelang.

M. н. WIтBOLS FEUGEN, Controleur le klasse, te Siak, Sumatra's Oostkust.

Jhr. o. VAN DER WIJCK, Referendaris ter Algemeene Secretarie, Batavia.

J. w. young, Tolk voor de Chineesche taal, Batavia.

B. vaN zUTPHEN, Resident van Bali en Lombok. 


\title{
L IJ S T
}

\author{
DE R \\ BINNEN- EN BUITENLANDSCHE ACADEMIËN, GELEERDE \\ GENOOTSCHAPPEN EN INSTELLINGEN,
}

\begin{abstract}
WAARMEDE HET KONINKLIJK INSTITUUT DOOR RUILING DER UITGEGEVEN
WERKEN IN VERBINDING IS.
\end{abstract}

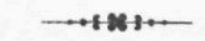

\section{NEDERLAND.}

Koninklijke Akademie van Wetenschappen, te Amsterdam.

Bibliotheek van de Universiteit van Amsterdam.

Aardrijkskundig Genootschap, gevestigd te Amsterdam.

Vereeniging voor de Statistiek in Nederland, te Amsterdam.

Nederlandsch Bijbelgenootschap, te Amsterdam.

Redactie van het Tijdschrift „De Rijnsche Zending. Tijdschrift ter bevordering van het Christendom in Nederlandsch-Indië” (Adres: de heer J. P. G. Westhoff, Amsterdam.)

Redactie van de „Indische Mercuur”, Amsterdam. (Rokin 60.)

Nederlandsche Maatschappij ter bevordering van Nijverheid, te Haarlem.

Teyler's Genootschap, Haarlem.

Bibliotheek der Rijks-Universiteit, te Leiden.

Rijks Ethnographisch Museum, Leiden.

Maatschappij der Nederlandsche Letterkunde, te Leiden.

Koninklijke Bibliotheek, te 's Gravenhage.

Bibliotheek van het Ministerie van Waterstaat, Handel en Nijverheid, te 's Gravenhage.

Bibliotheek van het Ministerie van Koloniën, te 's Gravenhage.

Koninklijk Instituut van Ingenieurs, te 's Gravenhage.

Indisch Genootschap, te 's Gravenhage.

Instelling van onderwijs in de taal-, land- en volkenkunde van Ned.-Indië, te Delft.

Instelling van onderwijs in de taal-, land- en volkenkunde van Ned.-Indië, te Leiden.

Historisch Genootschap, gevestigd te Utrecht.

Utrechtsche Zendingsvereeniging, te Utrecht.

Nederlandsch Zendelinggenootschap (Director. Dr. J. C. Neurdenburg), te Rotterdam.

Nederlandsche Zendingsvereeniging (Director R. Coolsma), te Rotterdam. 


\section{OOST-INDIË.}

Bataviaasch Genootschap van Kunsten en Wetenschappen, te Batavia. Koninklijke Natuurkundige Vereeniging in Nederl.-Indië, te Batavia.

Vereeniging tot bevordering der geneeskundige wetenschappen in Neder-

- landsch-Indië, te Batavia.

Koninklijk Instituut van Ingenieurs, afd. Nederl.-Indië, te Batavia.

Nederlandsch-Indische Maatschappij van Nijverheid en Landbouw te Batavia.

Vereeniging voor oudheid-, taal- en volkenkunde te Djokjakarta.

Redactie van het Indisch Militair Tijdschrift, te Batavia, Redacteur W. J. J. Ramaer, kapitein infanterie.

Bibliotheek van de Algemeene Secretarie, Batavia.

\section{BELGIË.}

Académie Royale des Sciences, des Lettres et des Beaux-Arts de Belgique, te Brussel. (Palais des Académies.)

Société Royale Belge de géographie, te Brussel. (171, Rue Potagère.)

Société scientifique de Bruxelles, te Brussel (14, rue des Ursulines.)

Société de géographie d'Anvers, te Antwerpen.

\section{FRANKRIJK.}

Société Asiatique, Parijs, 1, Rue de Seine. (Palais de l'Institut.)

Société de géographie de Paris, te Parijs.

Société d'ethnographie, te Parijs.

Société Académique Indo-Chinoise, te Parijs.

Société des études Japonaises, Chinoises, Tartares et Indo-Chinoises, te Parijs.

Athénée Oriental, rue du Cherche Midi 92, te Parijs.

Société des études coloniales et maritimes, te Parijs.

Muséum d'histoire naturelle, te Parijs.

École spéciale des langues Orientales vivantes, te Parijs.

Redactie van L'Exploration. (Redacteur P. Tournafond) Parijs.

Société de géographie commerciale de Bordeaux, te Bordeaux.

Société de géographie de Lyon, te Lyon.

Musée Guimet, 30 Avenue du Trocadero, Parijs.

Union géographique du Nord de la France, te Douai.

Société normande de géographie, te Rouaan.

Société de géographie de Tours, te Tours (Indre et Loire). (Adres: Secrétaire général, rue Etienne-Pallu, 25, à Tours).

Société de géographie et d'archéologie de la province d'Oran.

\section{SPANJE EN PORTUGAL.}

Sociedad geográfica de Madrid, te Madrid, Calle del Leon 21.

Sociedade de geographia de Lisboa, te Lissabon.

Sociedade de geographia commercial do Porto, te Porto.

Sociedade Portuense de geographia, te Porto.

Real Academia de Ciencias de Lisboa, te Lissabon. 


\section{ITALIË.}

Reale Accademia dei Lincei, te Rome.

Reale Istituto I oombardo di Scienze e Lettere, te Milaan. Mr. Uochli. Museo civico di storia naturali di Genova, te Genua.

Redactie van het Tijdschrift Cosmos. (Redacteur Guido Cora.) Turijn. Société Asiatique Italienne, Florence.

\section{RUSLAND, ZWEDEN EN NOORWEGEN.}

Académie Impériale des Sciences, te St. Petersburg.

Société Impériale géographique de Russie, te St. Petersburg.

Bibliothèque de l'Université Royale de Norvège, à Christiania.

\section{ZWITSERLAND, DUITSCHLAND, OOSTENRIJK.}

Geographische Gesellschaft von Bern, te Bern.

Königlich Preussische Akademie der Wissenschaften, te Berlijn.

General-verwaltung der Koeniglichen Museen, te Berlijn.

Hydrographisches Amt der Kaiserlichen Admiralität, Berlijn, W. Matthäikirchstrasse $n^{0} .9$.

Gesellschaft für Erdkunde, te Berlijn (Friedrichstrasse 191).

Deutscher Kolonialverein, Berlin S. W., Markgrafenstrasse 25 (Redaktion der Deutschen Kolonialzeitung.)

Geographische Gesellschaft in Bremen (Mendesstrasse 8).

Verein für Erdkunde, te Dresden.

Verein für Geographie und Statistik zu Frankfurt a/M.

Verein für Erdkunde, Kassel.

Verein für Naturkunde, Kassel.

Verein für Erdkunde, te Metz.

Historisch-litterarischer Zweigverein des Vogesenclubs in Elsass-Lothringen, Strassburg. (Adres: Kaiserliche Universitäts- \& Landesbibliothek zu Strassburg i. Els.)

Redactie der „Mitteilungen aus Justus Perthes' Geographischen Anstalt," te Gotha.

Königl. Gesellschaft der Wissenschaften zu Göttingen.

Verein für Erdkunde, te Halle an der Saale.

Verein für Erdkunde zu Leipzig (Brüderstrasse 23).

Deutsche Morgenländische Gesellschaft, Halle a. S.

Königliche Academie der Wissenschaften, te München.

De Redactie van het „Literatur-Blatt für Orientalische Philologie”, Redact. Prof. Dr. Ernst Kuhn in Munchen.

De Redactie van het Zeitschrift für wissenschaftliche Geographie (Red. J. I. Kettler), Weimar (Thüringen).

Wurttembergischer Verein für Handelsgeographie, Stuttgart.

Nassauische Verein für Naturkunde. (Adres; Dr. A. Pagenstecher, Secretär des Nassauischen Vereins für Naturkunde).

Geographische Gesellschaft für Thüringen, Jena. 
Kaiserliche Akademie der Wissenschaften, te Weenen.

Anthropologische Gesellschaft, te Weenen.

K. K. Geographische Gesellschaft, in Wien, I, Universitätsplatz No. 2.

K. K. Naturhistorische Hofmuseum, Weenen. (Wien, 1, Burgring).

Verein der Geographen an der Universität Wien.

Redactie van de Oesterr. Monatsschrift für den Orient, te Weenen (Red. A. Baron von Scala.)

\section{ENGELAND, BRITSCH-INDIË, CHINA, AUSTRALIË.}

Royal Colonial Institute, Northumberland Avenue, London W. C.

India Office, te Londen.

Royal Asiatic Society, 22 Albemarlestr. W., London.

Royal geographical Society, Burlingt. Gard. W., Londen.

Redactie van de „Proceedings of the Royal Geographical Society and

Monthly Record of Geography." (Clements R. Markham, te Londen.)

Scottish Głeographical Society, Edinburgh.

Asiatic Society of Bengal, Asiatic Society's Rooms, 57 Park Street, Calcutta.

Straits Branch of the Royal Asiatic Society, Singapore, Straits Settlements.

Ceylon Branch of the Royal Asiatic Society, te Ceylon.

North China Branch of the Royal Asiatic Society, te Shanghay.

Public Library of Victoria, te Melbourne.

Royal Society of Victoria, te Melbourne.

Tokio Geographical Society, te Tokio, Japan.

Société des études Indo-Chinoises de Saigon.

\section{AMERIKA.}

American geographical Society, te New-York.

Smithsonian Institution, Washington, U. S. A.

Director of the United States Geological Survey, Washington, D. c. U. S. A. American Academy of Arts and Sciences, Beacon street, Boston, Massachusetts. Sociedad Mexicana de geografia y estadistica, te Mexico. 


\section{4,sTe BESTUURSVERGADERTNG,}

GEHOUDEN 12 JUNI 1886.

Tegenwoordig de heeren van Rappard (Voorzitter), van Deventer (Onder-voorzitter), J. H. de Groot (Penningmeester), Robidé van der Aa, Matthes, Juynboll, Niemann, Kielstra, Riedel, Schlegel, Snouck Hurgronje, Wilken en Wijnmalen (Secretaris).

De notulen van het verhandelde in de vorige Vergadering worden gelezen en goedgekeurd.

Der Vergadering wordt vervolgens medegedeeld met welke boekwerken de Bibliotheek sedert de vorige bijeenkomst werd verrijkt, waarbij tevens voorlezing wordt gedaan van

$\boldsymbol{a}$. een schrijven van den Secretaris der Matschappij van Nederlandsche letterkunde te Leiden, ten geleide van een exemplaar van den Catalogus der Bibliotheek, deel II, afl. 1.

b. eene missive van dr. D. R. Capriles, te Curaçao, ten geleide van een exemplaar van het "Anuario Estadistico" van den Staat Zulia, Venezuela, met verzoek te willen mededeelen of werken van dien aard betreffende de Zuid-Amerikaansche Staten voor de Bibliotheek welkom zouden zijn.

Onder dankbetuiging worden de geschonken boekwerken aanvaard, met machtiging aan den Secretaris-Bibliothecaris om de vraag des heeren Capriles te beantwoorden.

Ter tafel wordt gebracht een schrijven van den Directeur van 's Rijks Ethnographisch Museum, te Leiden, houdende mededeelingen omtrent de vervaardiging, door dr. B. Hagen, van een photographisch album, voorstellende de verschillende rassen en volksstammen die in het Delische zijn aan te treffen, met verzoek om een exemplaar van dit werk, waarvan slechts een beperkt getal zal worden 
verkrijgbaar gesteld, tegen $f 75$ voor de Bibliotheek van het Instituut te willen inteekenen.

$\mathrm{Na}$ eenige gedachtenwisseling wordt, overeenkomstig het advies van den Secretaris, besloten aan het verzoek te voldoen.

Verder wordt de ontvangst bericht van

10. eene missive van den heer J. G. Robbers, van 5 Mei jl., houdende mededeeling van de aanvaarding van het lidmaatschap van het Instituut met ingang van 1 Juli a. s.

20. eene missive van den heer dr. D. R. Capriles, te Curaçao, van 10 April jl., waarbij hij verklaart gaarne zijne benoeming tot lid van het Instituut aan te nemen.

Beide missives worden voor kennisgeving aangeuomen.

30. eene missive van den Algemeenen Secretaris van het Algemeen Nederlandsch Vredebond te 's Gravenhage, van 9 Juni jl.. waarbij verzocht wordt, om, evenals drie jaren geleden, over het Bestuurslokaal van het Instituut te mogen beschikken voor de Algemeene Vergadering van het Bond, welke bepaald is op Woensdag 7 Juli a. s. des namiddags ten 2 ure.

Overeenkomstig het advies van den Secretaris wordt besloten de gevraagde vergunning te verleenen.

Naar aanleiding van hetgeen in de vorige Vergadering was besloten omtrent het door den hoogleeraar de Goeje gedaan voorstel tot subsidieering van eene aan den Arabier Seyid Othman-ibn-Jahja op te dragen zending naar Hadramaut, deelt de Voorzitter mede, dat aan Z. Exc. den Minister van Koloniën den 20n Mei jl. een adres is verzonden, houdende verzoek dat vanwege zijn Departement voor het gemelde doel aan het Instituut eene tegemoetkoming .worde verleend tot een bedrag dat de Minister oorbaar zal achten, doch in geen geval de som van éen duizend gulden zal behoeven te overschrijden. Na de indiening van dit adres is door hem met den Secretaris eene audientie bij den Minister aangevraagd en verkregen, bij welke gelegenheid hij an genoemden Bewindsman nadere inlichtingen heeft verstrekt omtrent het doel en het gewicht der voorgenomen zending, welke in diens krachtige ondersteuning en medewerking werd aanbevolen. De Minister gaf echter te kennen, over het ingediende voorstel geen beslissing te mogen nemen, alvorens het advies der Indische autoriteiten daarover te hebben ingewonnen; dit bleek ook uit eené officieële missive van den Minister van Koloniën zelven, 
van den 28 Mei jl. Lett. A $\mathbf{1}, n^{\mathbf{0}}, 41$, waarin, naar aanleiding van het gemeld dezerzijdsch schrijven van $20 \mathrm{Mei}$, jl. no. 63 , wordt te kennen gegeven, dat omtrent het daarbij gedaan verzoek het advies is gevraagd van den Gouverneur-Generaal van N.-I.

Deze mededeeling wordt voor kennisgeving aangenomen.

Door den Secretaris wordt de wijze van uitgave van het werk des heeren Snouck Hurgronje besproken, waaromtrent ook de schrijver zelf nadere breedvoerige inlichtingen geeft, terwijl algemeene toejuiching vindt het denkbeeld om aan het Departement van Koloniën in overweging te geven door ruime inteekening op het uit te geven werk de kosten, aan de uitgave verbonden, voor een deel te verminderen. Nog wordt, met het oog op de kostbaarheid der uitgave, in bedenking gegeven haar niet kosteloos aan de leden uit te reiken.

$\mathrm{Na}$ gedachtenwisseling over een en ander wordt eenparig besloten, aan den Secretaris en den Penningmeester op te dragen, in overleg met den heer Snouck Hurgronje, de noodige maatregelen te nemen ter verzekering der voorgenomen uitgave, den Minister van Koloniën, te verzoeken daarop voor een zeker getal exemplaren in te teekenen, en omtrent de gratis-uitreiking van het werk aan al de leden later de noodige voorstellen aanhangig te maken.

Ter tafel wordt gebracht het handschrift des heeren Corns de Groot, bevattende zijne "Herinneringen aan Blitong," waaromtrent achtereenvolgens de heeren Kielstra, Riedel en Martin verslag uitbrengen, terwijl de Secretaris daaraan eenige mededeelingen toevoegt omtrent de kosten eener eventueele uitgave van het werk, over den inhoud waarvan de Schrijver zelf nader uitweidt in een schrijven van 17 Mei jl.

Met het oog op den grooten omvang der studie - nu reeds beslaat het eerste gedeelte daarvan, naar ontvangen raming, 15 à 16 vellen druks, terwijl het nog te bewerken gedeelte een niet minder aantal vellen zal vorderen - , waarbij nog komt de reproductie van de geologische kaart en platen, wordt de uitgave daarvan in haar geheel voor het Instituut te kostbaar geacht; bovendien zou, meent men, het geognostisch gedeelte der verhandeling, dat reeds ontvangen is en alsnog verwacht mag worden, elders meer de aandacht trekken dan wanneer het vanwege het Instituut werd uitgegeven. Der Vergadering wordt daarom in overweging gegeven, om, onder mededeeling van een en ander aan den Schrijver, hem 
tevens te berichten, dat vanwege het Instituut, en wel in een der afleveringen van de Bijdragen alléén worde uitgegeven dat gedeelte van zijne "Herinneringen ", dat handelt over de oude geschiedenis van Blitong, meer speciaal omtrent de verhouding van de hoofden en bevolking van dit eiland tot de V. O.-I. Compagnie, en waarbij een relaas van schrijvers bevindingen in 1851 en 1862 is gevoegd.

Dienovereenkomstig wordt besloten.

Met instemming van den heer van Deventer wordt door den heer Robidé van der. Aa het volgend rapport uitgebracht over het in hunne handen gesteld handschrift, bevattende een "Kort overzigt der Lampongsche Provintiën door den Assistent-resident J. D. Kruseman, dd. 28 December 1817" :

"Ongetwijfeld is dit handschrift eene belangrijke aanwinst voor de verzameling officieële bescheiden, die het Kon. Instituut nu reeds bezit. De belangstellende onderzoeker kan er uit leeren, hoe het er in de Lampongs uitzag, toen bij het herstel van het Noderlandsch gezag in den Archipel dit gewest voor het eerst onder rechtstreeksch Europeesch beheer gebracht werd.

"Welke waarde dit handschrift ook voor den geschiedvorscher bezitte, toch durf ik niet aanraden, dat het alsnog in zijn geheel worde uitgegeven. Er is toch, bepaaldelijk uit de eerste helft dezer eeuw, reeds veel over de Lampongs gepubliceerd. Bijzonder verdienen als zoodanig de aandacht de aanteekeningen van den kundigen du Bois , die kort na Kruseman zestien jaren in de Lampongs gezag voerde, welke gegevens in verschillende jaargangen van het "Tijdschrift voor "Ned. Indië zijn uitgegeven. Daarentegen berust het Overzicht van Kruseman op waarnemingen gedurende een nauwelijks driemaandelijksch tijdperk, waarbij de slechte staat zijner gezondheid hem volgens zijn eigen getuigenis zeer in zijne taak belemmerde. Vooral in het eerste tijdvak, dat de Lampongs onder Nederlandsch gezag stonden, waren de toestanden er stationnair genoeg, dat het overbodig geacht mag worden, dit handschrift - waarvan bij eene eventueele uitgave taal en stijl duchtig gekuischt zouden moeten worden - - in onze Bijdragen optenemen. "

Eenparig vereenigt de Vergadering zich met de conclusie van dit rapport.

De heeren Matthes en Niemann brengen verslag uit over het in 5e Volgr. II. 
hunne handen gesteld opstel van den heer Harmsen over het Nederduitsch-Maleisch woordenboek van den heer Klinkert. Beiden adviseeren zij tot opneming daarvan in de Bijdragen, behoudens eenige door hen aangewezen wijzigingen en uitlatingen, zoo althans bij den Schrijver daartegen geene bedenking mocht bestaan.

Dienovereenkomstig wordt eenparig besloten.

Namens Commissarissen in Indië brengt de Secretaris ter tafel een tweetal opstellen, welke hem door den heer Harrebomée ter hand zijn gesteld ter opneming in de Bijdragen. Om bericht en raad in handen gesteld van de heeren Wilken en Niemann.

Met het oog op het niet meer voorhanden zijn der diploma's, welke aan nieuwbenoemde leden zouden kunneu worden uitgereikt, brengt de Secretaris eenige modellen ter tafel, waaruit hij de Vergadering verzoekt eene keuze te willen doen. Na inzage daarvan besluit de Vergadering eene proef te doen geven van een nieuw diploma door een gunstig bekende drukkersfirma hier ter stede.

Op voorstel van den heer Schlegel wordt tot buitenlandsch lid van het Instituut benoemd de heer Jules Silvestre, oud-resident van Hanoï in Tonking, thans te Rochefort sur mer, 2 Rue des Fonderies, Charente inférieure, Frankrijk, stichter en oprichter van de Société libre d'études indochinoises te Saigon, en schrijver van verscheidene werken, waaronder een over het muntstelsel in Cochinchina.

De heer Snouck Hurgronje deelt mede dat hij voor het Orientalisten-Congres te Weenen eene verhandeling heeft gereed gemaakt over de Mekkaansche spreekwoorden, welke hij gaarne opgenomen zou zien in de in October a. s. verschijnende aflevering der Bijdragen. Overeenkomstig het advies van den Secretaris wordt besloten de verhandeling voor gemelde aflevering te bestemmen, met dien verstande echter, dat zij bij de firma Brill ter perse worde gelegd, en dat daarvan overdrukken worden gemaakt, waarvan een zeker getal afzonderlijk in den handel zou kunnen worden gebracht, terwijl de heer Snouck Hurgronje zal worden verzocht eenige exemplaren, als feestgave van het Instituut, aan te bieden aan het Bureau van het aanstaand Orientalisten-Congres te Weenen.

Met het oog op dat Congres worden tevens tot afgevaardigden van het Instituut benoemd de hh. Schlegel en Snouck Hurgronje, 
aan wie te zijner tijd de noodige geloofsbrieven zullen worden uitgereikt, terwijl van hunne benoeming aan het Bureau van het Congres zal worden kennis gegeven.

Niets meer hierna aan de orde zijnde, wordt de Vergadering door den Voorzitter gesloten.

\section{STE BESTUURSVERGADERING.}

GEHOUDEN 18 SEPTEMBER 1886.

Tegenwoordig de hh. van Rappard (Voorzitter), van Deventer (Onder-voorzitter), J. H. de Groot (Penningmeester), Wilken, Juynboll, Niemann, Riedel, Kielstra en Wijnmalen (Secretaris). Afwezig met kennisgeving de hh. Schlegel, Matthes en Snouck Hurgronje.

De notulen van het verhandelde in de vorige Vergadering worden gelezen en goedgekeurd.

De Secretaris vestigt de aandacht der Vergadering op de verschillende critische aankondigingen van de jongste werken van het Instituut, met name van de Bijdragen, 4e Serie, dl. X en 5e Serie dl. I, in "Le Muséon", dl. V, 3; in no. 28 van het "Literarischen Centralblatt"; in de "Deutsche Litteraturzeitung", van 4 September 1886, VII Jahrg. no. 36; in "Trübner's American, European, and Oriental Literary Record, N. S. vol. VII, nos 3/4; en van Dr. K. Martin's "Bericht über eine Reise ins Gebiet des oberen Surinam" in "Der Naturforscher" van 24 Juli 1.l. Jahrg. XIX, no. 30.

Van een en ander wordt door de Vergadering met belangstelling kennis genomen, alsmede ook van de mededeeling, met welke boekwerken de Bibliotheek sedert de laatste Vergadering, 't zij door aankoop, 't zij door geschenken werd vermeerderd, waarbij tevens worden voorgelezen missives

10. van den Minister van Waterstaat, Handel en Nijverheid, dd. Juni 1886, ten geleide van een exemplaar van de le aflevering van de "Verzameling van consulaire en andere verslagen en berichten 
voor nijverheid, handel en scheepvaart", jaargang 1886, onder mededeeling, dat de verdere afleveringen vanwege het Departement achtereenvolgens zullen worden toegezonden;

20. van de Kaiserliche Admiralität, Hydrographiches Amt, te Berlijn, dd. 29 Juni 1886 , ten geleide van een exemplaar van de "Ergebnisse der Untersuchungsfahrten S. M. Kanonenboot "Drache" in der Nordsee" ;

30. van het Bestuur van het Württembergischen Verein für Handelsgeographie, te Stuttgart, ten geleide van het III/IV Jahresbericht;

40. Van H. H. Risley, Esq., Bengal Civil Service, Darjeeling, Bengal, ten geleide van eenige geschriften . betreffende ethnographische onderzoekingen in Bengalen.

Al deze missives worden voor kennisgeving aangenomen, met plaatsing der daarin vermelde boekwerken in de Bibliotheek, onder dankzegging aan de inzenders.

Verder zijn ingekomen:

10. eene missive van de Koninklijke Akademie van Wetenschappen te Amsterdam van 25 Febr. 1886, no. 4, houdende dankbetuiging voor de toezending van de 10 afl., deel I, 5e Reeks der Bijdragen.

20. eene missive van de Sociedad Mexicana de geografia y estadistica, te Mexico, houdende dankbetuiging voor de toezending van de Bijdragen, 1886.

30. drie missives van de Académie Royale des sciences de Lisbonne van 23 Jan., 27 April en 7 Juli 1886, houdende bericht van ontvangst van en dankbetuiging voor de afl. 1,2 en 3, deel I, 5e Reeks der Bijdragen.

Al deze missives worden voor kennisgeving aangenomen.

40. eene missive van den Directeur van 's Rijks Ethnographisch Museum te Leiden, van 10 Juli ll., no. 102, waarbij, in antwoord op het schrijven dezerzijds van 17 Juni 1886 , no. 65 , bericht wordt dat het typen-album van dr. Hagen te zijner tijd aan het Bestuur zal worden toegezonden.

Aangenomen voor kennisgeving.

50. eene missive van de Directie van de Société de sciences et 
de géographie te Port-au-Prince, waarbij mededeeling wordt gedaan van de oprichting van het Genootschap, met rerzoek het te willen opnemen op de lijst der wetenschappelijke instellingen, waarmede het Instituut in betrekking staat.

Eene beslissing omtrent dit verzoek wordt aangehouden tot na den ontvangst van nadere mededeelingen omtrent de strekking en werkzaamheden van het nieuwe Genootschap.

De Voorzitter deelt verder mede, dat bericht is ingekomen van het overlijden van de leden G. Du Ry van Beest Holle, te 's Gravenhage, prof. dr. E. H. Iasonder, te Utrecht, D. Scheltema te Haarlem, prof. J. J. Meinsma, te Delft, aan wier nagedachtenis een woord van hulde wordt gewijd, terwijl nog besloten wordt aan Mevrouw de wed. Meinsma-Immerzeel de deelneming van het Bestnur te betuigen wegens het overlijden van haren echtgenoot, die, gedurende zijn leven, meermalen als lid van het Bestuur, de belangen van het Instituut krachtig heeft bevorderd.

Nog zijn ingekomen :

10. missives van de heeren A. W. Egter van Wissekerke, te 's Gravenhage, en J. H. Donner, te Leiden, beiden houdende verzoek hunne namen van de lijst der leden te willen afvoeren.

20. eene missive van den Secretaris der Vereeniging Pomona, te Menado, van 16 Mei jl., houdende verzoek om de Vereeniging in te schrijven als contribueerend lid van het Instituut en zijne uitgaven te zenden aan het adres van den heer J. P. von Strachwitz, administrateur van het erfpachtsland Boijong, Boijong di atas, Amoeroeng, Menado.

30. eene missive van den heer J. Silvestre, te Rochefort sur mer, waarbij hij, onder dankbetuiging voor de onderscheiding, hem bewezen, gaarne de benoeming tot buitenlandsch lid van het Instituut aanvaardt.

40. eene missive van den heer D. Aitton, leeraar aan het Gymnasium, te 's Gravenhage, houdende kennisgeving van de aanvaarding van het lidmaatschap.

50. eene missive van den Majoor-titulair der Chineezen, te Samarang, Be Biauw Tjoan, waarbij hij, gevoelig voor de onderscheiding 
hem ten deel gevallen, kennis geeft, dat het hem aangenaam zal zijn als Lid-donateur van het Instituut te worden opgenomen.

60. eene missive van den Kapitein der Chineezen, te Soerabaja, Tjoa Djien Sing, houdende mededeeling van de aanvaarding van het hem aangeboden lidmaatschap van het Instituut, met bericht tevens dat de jaarlijksche contributie aan het Agentschap te Batavia zal worden geremitteerd.

70. vier briefkaarten van Commissarissen van het Instituut te Batavia, waarbij wordt medegedeeld:

a. dat tot leden van het Instituut zijn toegetreden de heeren H. W. Bosman, Tweede onderwijzer te Probolinggo, W. van Gelder, Hoofdonderwijzer te Bandoeng, J. B. Neumann, Controleur te Sidjoendjoeng (Sumatra's Westkust), W. H. Vrijburg van der Hell, Aspirant-controleur te Soekaboemi en W. Hoogkamer, Assistent-resident te Fort van der Capellen, met verzoek aan allen de uitgaven over het loopende jaar te willen toezenden;

b. dat het lid mr. G. J. van Berckel is overgeplaatst naar-Banda (Molukken);

c. dat het lid P. Jansz verzocht heeft met 1 Januari 1887 van de ledenlijst te worden afgevoerd; en

d. dat het lid J. A. B. Wiselius heeft bericht sedert September 1885 geene edita ontvangen te hebben, zoodat hij toezending verzocht van deel I, vijfde volgreeks en volgende, der Bijdragen.

80. eene missive van het lid Twiss, te Indrapoera, houdende verzoek de voor hem bestemde werken van het Instituut te willen doen verzenden aan zijn adres te Natal, Residentie Tapanoeli, Gouvernement Sumatra's Westkust.

90. eene missive van den heer L, van Koetsveld, te Rotterdam, houdende: mededeeling, dat zijn zoon, C. P. J. van Koetsveld, lid van het Instituut, thans gevestigd is als Assistent-Resident te Koetei, op Borneo, en de stukken van het Instituut a]zoo aan dat adres kunnen worden afgezonden.

Van de in al de missives en briefkaarten, sub $10-90$, voorkomende mededeelingen en inlichtingen zal door den Secretaris en Penningmeester aanteekening worden gehouden. 
Ter tafel wordt gebracht een schrijven van het lid dr. Horst, te Ternate, waarbij het verzoek wordt gedaan den $2 \theta$ luitenant der Infanterie C. J. Okhuizen, te Ternate tot lid van het Instituut te willen benoemen.

Dienovereenkomstig wordt besloten, terwijl alsnog tot leden worden aangenomen de heeren $\mathrm{mr}$. J. de Wal, benoemd Rechterlijk Ambtenaar in Oost-Indië, thans te Leiden, en C. W. F. Kooiman, benoemd Oost-Indisch Ambtenaar.

Namens Bestuurders van het Algemeen Nederlandsch Vredebond te 's Gravenhage is een schrijven van den Algemeenen Secretaris, mr. G. Belinfante, van 8 Juli ll. ontvangen, houdende dankbetuiging voor de hun door het Instituut betoonde gastvrijheid, waardoor de Algemeene Vergadering van het Vredebond in het daartoe zoo uitmuntend geschikt vergaderlokaal van het Instituut mocht worden gehouden: welk blijk van welwillendheid op hoogen prijs wordt gesteld, terwijl men de vrijheid neemt zich daartoe ook in het vervolg aan te bevelen.

Voor kennisgeving aangenomen.

Door den Secretaris wordt mededeeling gedaan van een door hem ontvangen schrijven van het medelid mr. A. J. Bik, te Amsterdam, waarbij zijne tusschenkomst wordt gevraagd om aan den heer Whitehead, die in de plant- en dierkunde gepromoveerd is en hoofdzakelijk de flora en fauna van de landen die hij doorreist bestudeert, brieven van aanbeveling te bezorgen voor eene aanstaande reis met eigen stoomjacht naar Zuid-Borneo. In antwoord daarop is door hem te kennen gegeven, dat aan den heer Whitehead de raad kan worden gegeven zich voor het verkrijgen van doeltreffende brieven van aanbeveling langs diplomatieken weg te wenden tot den Minister van Koloniën, terwijl de Secretaris zelf zich bereid verklaart te zijner tijd den reiziger aan te bevelen aan de Commissarissen van het Instituut te Batavia.

Een en ander wordt voor kennisgeving aangenomen.

De Secretaris deelt mede, dat door den hoogleeraar Prof. dr. K. Martin, te Iueiden, het verzoek is gedaan om ten behoeve van zijn eerlang uit te geven werk over West-Indië ook te mogen beschikken over zijn in de Bijdragen opgenomen "Bericht über eine Reise ins gebiet des oberen Surinam." Wegens het spoedeischende der zaak is aan- 
stonds aan den Hoogleeraar bericht, dat daartegen bij het Instituut geene bedenking bestaat; de Secretaris verzoekt echter de goedkeuring der Vergadering voor deze zijne handeling. Zonder beraadslaging wordt zij eenstemmig verleend.

Door tusschenkomst van Mejuffrouw Th. Groneman, te Arnhem, is den Secretaris ter hand gesteld een concept-voorstel, door haren Vader, den heer dr. J. Groneman, Voorzitter van de Djokjasche Vereeniging voor taal-, land-, oudheid- en volkenkunde van MiddenJava (Mataram), in de Bestuursvergadering dier Instelling van 29 Juni 1886 ter tafel gebracht, doch voorloopig niet ter opzending aan het Bataviaasch Genootschap van Kunsten en Wetenschappen aangenomen, waarop men echter hoopt terug te komen: welk voorstel meer kans van slagen zou hebben, indien het ook den steun zou kunnen erlangen van andere mannen van gezag en vereenigingen, en daaronder ook van het Instituut.

Het concept-voorstel moet strekken om geldelijken steun te verkrijgen voor het ontgraven, afbeelden en weer in elkaâr zetten van beela'werken van Boroboedoer, waaromtrent de plannen uitvoerig worden medegedeeld.

Van een en ander wordt door de Vergadering met belangstelling kennis genomen. Bij de gedachtenwisseling daarover wordt echter meer bepaald het tijdige van den an het concept-voorstel te verleenen steun besproken waarna wordt besloten de beslissing daarover aan te houden, terwijl inmiddels den Secretaris wordt opgedragen nadere inlichtingen in te winnen omtrent de bedoeling van den geëerden Voorsteller.

Ter tafel wordt gebracht een schrijven van Commissarissen te Batavia, van 11 Mei 1886, No. B/129, houdende $a$ : aanbieding van een secunda-wissel van 4. Februari 1886, groot $f 250.63$; en b. antwoord op het schrijven dezerzijds van Maart ll., no. 56, waaruit, nevens enkele verbeteringen en veranderingen in de ledenlijst, blijkt: $1^{0}$. dat als leden van het Instituut zijn toegetreden de hh. Dr. H. de Cock, arts en officier van gezondheid te Kajoe Tanam (Sumatra's Westkust), F. E. Luitjes, $2^{\mathrm{e}}$ onderwijzer aan de kweekschool voor inlandsche onderwijzers te Ambon en J. J. Meijer, controleur der $2^{\circ}$ klasse te Rangkasbetoeng (Bantam), aan wie de edita over het geheele loopende jaar moeten worden gezonden;

20. dat omtrent de letterkundige nalatenschap van den luitenant 
Campen te Gombong een onderzoek zal worden ingesteld, waarvan het resultaat te zijner tijd zal worden medegedeeld;

30. dat ten aanzien der gestelde vraag, of en in hoever ook voor Ned. Indië een werk kan worden geleverd in den geest van het "Lapidarium Ceylanicum", het advies is gevraagd van den heer H. M. La Chapelle, te Batavia, dat te zijner tijd zal worden medegedeeld; terwijl, eindelijk,

$44^{0}$. ten gerieve van de door het Instituuts-bestuur benoemde Commissie, die advies moet uitbrengen over hetgeen er verricht moet worden ter bewaring der Hindoe-monumenten in Midden-Java, uitvoerige inlichtingen worden verstrekt omtrent hetgeen dienaangaande vanwege het Bataviaasch Genootschap dusver werd gedaan.

$\mathrm{Na}$ eenige gedachtenwisseling wordt besloten, onder dankbetuiging aan Commissarissen voor hun schrijven, voor zooveel noodig aanteekening te houden van de daarin vervatte mededeelingen, terwijl van de sub 40. vermelde inlichtingen kennis zal worden gegeven aan de Commissie, bestaande vit de hh. Juynboll en Wijnmalen, met uitnoodiging daarover te zijner tijd rapport uit te brengen.

Van den Minister van Koloniën is eene missive ontvangen, dd. 9 September jl. Lett. $\mathrm{A}^{\mathrm{I}}$, $\mathrm{n}^{\mathrm{o}}$. 10, waarbij, met referte aan het schrijven van 28 Mei te voren, $\mathrm{L}^{\mathrm{a}} \mathrm{A}^{\mathrm{I}}$, $\mathrm{n}^{\circ}$. 41, wordt medegedeeld, dat, op grond van de door den Gouverneur-Generaal van N.-I. aangevoerde bezwaren, geen termen gevonden kunnen worden tot inwilliging van het verzoek van het Instituut om eene subsidie als tegemoetkoming in de kosten eener wetenschappelijke expeditie naar Hadramaut.

Overeenkomstig het voorstel van den Secretaris wordt besloten zich andermaal tot den Minister van Koloniën te wenden, met het verzoek het Bestuur vertrouwelijk in kennis te willen stellen van de bedenkingen, die tegen de voorgenomen wetenschappelijke expeditie naar Hadramaut door de verschillende Indische autoriteiten zijn in het midden gebracht, daar het voor het Bestuur van het hoogste belang is daarvan niet onkundig te blijven, waar het thans de vraag moet beslissen, of het raadzaam is dat het Instituut het voorgenomen onderzoek geheel of gedeeltelijk voor zijne rekening neme.

In antwoord op het schrijven van het Instituutsbestuur van 16 Augustus 1l., no. 70, is eene missive van den Minister van Koloniën ontvangen, dd. 7 September jl. Lett. A ${ }^{\mathrm{I}}$, no. 9, waarin wordt 
medegedeeld, dat bij Koninklijk besluit van 1 Sept. jl. no. 23 de vereischte machtiging is verleend om van Regeeringswege in te teekenen op honderd exemplaren van het door het Instituut uit te geven werk van dr. Snouck Hurgronje over zijne reis naar Arabië. Mitsdien kunnen, telkens wanneer een deel compleet is, 100 exemplaren aan het Departement gezonden worden, vergezeld van eene declaratie in duplo, waarvan één exemplaar op zegel.

Deze missive wordt voor kennisgeving aangenomen, waarna door den Secretaris wordt medegedeeld, dat de prijs voor elk exemplaar van het uit te geven werk is gesteld op $f$ 15; dat na gehouden overleg met de hh. Nijhoff en de firma. Brill eerstgenoemde als uitgever zal optreden, terwijl, behoudens zijn toezicht, de uitvoering van het werk is opgedragen aan de laatstgenoemde firma; dat de kosten voor eene oplaag, geheel gereed, van 1000 exemplaren, groot 4,0 met inbegrip van de kosten der reproductie van de platen, geraamd zijn op $f 3000$ à $f 3500$.

$\mathrm{Na}$ gedachtenwisseling wordt een en ander door de Vergadering goedgekeurd en de Secretaris gemachtigd, in overleg met dr. Snouck Hurgronje, voor de uitgave van het werk zorg te dragen, terwijl voorts bepaald wordt de oplaag daarvan te stellen op 1000 exemplaren en in de eerstvolgende Algemeene Vergadering het voorstel te doen het hierbedoelde werk niet kosteloos aan de leden te verstrekken, doch hen in de gelegenheid te stellen het voor verminderden prijs te verkrijgen.

Door de heeren Niemann en Wilken wordt achtereenvolgens rapport uitgebracht over een tweetal in hunne handen gestelde bijdragen van het lid G. J. Harrebomée, bevattende "Twee honderd korte volzinnen in het Agamsch" en "Honderd korte volzinnen in het Mandailingsch". Eveneens wordt door laatstgenoemdeu Rapporteur, mede uit naam van den Hoogleeraar Dr. H. Kern, advies uitgebracht omtrent eene derde bijdrage des heeren Harrebomée, bevattende een "Minnezang" in het Agamsch, met vertaling en aanteekeningen. Zoowel met 't oog op de spelling als omdat de zuiverheid van taal nog al veel te wenschen overlaat, wordt de uitgave der drie aangeboden opstellen door de adviseurs ontraden.

Eenparig vereenigt de Vergadering zich met dit advies.

Door den Secretaris worden, namens het lid G. J. Harrebomée, der Vergadering aangeboden de door hem nader bij- en omgewerkte 
Nederlandsch-oeloesche en Oeloesch-nederlandsche woordenlijsten. Om bericht en raad in handen gesteld van de heeren Wilken en Niemann.

Door het bestuurslid Kielstra wordt, ter plaatsing in de Bijdragen, angeboden een door hem bewerkt opstel over de geschiedenis van Sumatra's Westkust van 1819-1825, waarvan de geest en strekking door den Schrijver kortelijk worden toegelicht.

De Voorzitter dankt het bestuurslid Kielstra voor zijne bijdrage, en stelt voor haar in de eerstvolgende aflevering van het Tijdschrift, die van Januari a. s., op te nemen, althans, zoo noodig, voor een gedeelte, terwijl het slot eene plaats in een der volgende afleveringen zou kunnen erlangen. Dienovereenkomstig wordt besloten.

Door den Secretaris wordt ter tafel gebracht een ontwerp voor een diploma, aan nieuw benoemde leden uit te reiken. $\mathrm{Na}$ inzage daarvan wordt het door de Vergadering goedgekeurd en de Secretaris gemachtigd, in overleg met den Penningmeester, daarvan de noodige afdrukken te doen maken.

Door den Secretaris en Penningmeester wordt verslag uitgebracht omtrent de hun door de firma Nijhoff angeboden rekening en verantwoording van de door haar verkochte werken van het Instituut over het jaar 1885. Daaruit blijkt dat de totale verkoop eene som vertegenwoordigt van $f 2,368.90$, waarvan ten bate van het Instituut een saldo anwezig is van $f 1,413.94$, over welke som de Penningmeester bereids beschikt heeft.

Overeenkomstig het voorstel van den Secretaris en Penningmeester wordt besloten de ingediende rekening goed te keuren.

Door den Penningmeester wordt de aandacht der Vergadering gevestigd op de hooge assurantie-premie, die het Instituut jaarlijks te betalen heeft voor zijne verzekering van het gebouw, het meubilair en de bibliotheek: waarom het voorstel wordt gedaan, om, nu met ulto. Dec. a. s. het contract met de Haagsche Assurantie-Maatschappij eindigt, het niet verder te verlengen, en te trachten bij eene andere maatschappij voordeeliger voorwaarden te bedingen. Dienovereenkomstig wordt eenparig besloten.

Niets meer hierna aan de orde zijnde, wordt de Vergadering door den Voorzitter gesloten. 


\section{STE BESTUURSVERGADERING,} GEHOUDEN 16 OCTOBER 1886.

Tegenwoordig de heeren van Rappard (Voorzitter), van Deventer (Onder-voorzitter), J. H. de Groot (Penningmeester), Matthes, Kielstra, Schlegel, Snouck Hurgronje, Wilken, Juynboll, Nieman en Wijnmalen (Secretaris). Afwezig, met kennisgeving, de heeren Robidé van der Aa en Riedel.

De notulen van het verhandelde in de vorige Vergadering worden gelezen en goedgekeurd.

Door den Secretaris-Bibliothecaris wordt opgave gedaan van de ontvangen boekwerken, waarbij tevens wordt voorgelezen:

10. eene missive van den heer A. Werumeus Buning, Directeur van het Museum voor Land- en Volkenkunde en het Maritiem Museum "Prins Hendrik" te Rotterdam, ten geleide van een door hem geschreven artikel in het tijdschrift "De Huisvriend", betreffende het gemeld Museum.

20. eene missive van Prof. Mr. P. A. van der Lith, te Leiden, ten geleide van het $2^{\theta}$ gedeelte van zijn werk over de "Merveilles de l'Inde."

30. eene missive van het Bestuur der Ned.-Indische JuristenVereeniging te Batavia, ten geleide van een exemplaar van de Handelingen dier Vereeniging over 1886, deel I en II.

4.0. eene missive van den Secretaris des Vereins für Naturkunde te Cassel, houdende dankbetuiging voor den gelukwensch bij gelegenheid van het 50jarig bestaan dier instelling, onder aanbieding tevens van een exemplaar van het toen uitgegeven "Festschrift".

$\mathrm{Al}$ deze missives worden voor kennisgeving aangenomen, terwijl de aangeboden werken in de boekerij zullen worden opgenomen, onder dankbetuiging aan de inzenders.

Ter tafel worden gebracht:

10. eene missive van het Smithsonian Institution te Washington City, U. S. A., houdende bericht van ontvangst van en dankbetuiging voor de toegezonden Bijdragen, 4e reeks, deel $\mathrm{X}, 3,4$ en 5 e reeks, I, 1, 2 en "Het Kongsiwezen van Borneo" door Dr. J. M. de Groot.

Voor kennisgeving aangenomen. 
20. eene missive van de Redactie van den Rijks- en ResidentieAlmanak voor het Koninkrijk der Nederlanden, te 's Gravenhage, houdende verzoek de opgaven betreffende het Instituut te willen nazien en, zoo noodig, te verbeteren.

De Secretaris deelt mede dat hij de gezonden opgave bereids met de noodige verbeteringen heeft teruggezonden.

30. eene missive van Jhr. W. H. Teding van Rerkhout, te 's Gravenhage, houdende verzoek hem met den aanvang van het volgend jaar van de ledenlijst af te voeren.

Voor kennisgeving aangenomen.

Overeenkomstig het voorstel van den Secretaris worden tot leden van het Instituut voorgedragen en benoemd de heeren S. W. Tromp, laatstelijk assistent-resident van Koetei, thans met verlof, J. W. IJzerman en A. van Leeuwen, kapitein van het O.-I. leger, allen te 's Gravenhage, terwijl gevolg wordt gegeven aan den wensch des heeren K. F. H. van Langen, laatstelijk assistent-resident van Groot-Atjeh, thans met verlof, tot intrekking van zijn verzoek om ontslag als lid van het Instituut.

Aanteekening wordt gehouden van de mededeeling des heeren N. Graafland, Adjunct-Inspecteur van het inlandsch onderwijs in de Molukken, dat zijn adres voortaan is: Ambon.

Door den Secretaris wordt medegedeeld, dat de hoogleeraar Vreede hem zijn wensch heeft te kennen gegeven om in de eerstvolgende aflevering der Bijdragen een woord te wijden aan de nagedachtenis van Prof. Meinsma, in leven lid en oud-bestuurder van het Instituut, terwijl hij zal zorgen dat het opstel tegen 15 November a. s. in het bezit der Redactie zal zijn. Voor kennisgeving aangenomen.

Van den heer Mart. Nijhoff is eene missive van den 20 Sept. jl. ontvangen, houdende mededeeling van het antwoord der firma Kolff en Co., te Batavia, betreffende het vestigen in Indië van een depôt der werken van het Instituut. Daaruit blijkt, dat men niet gelooft, dat daarvan iets verwacht kan worden, doch voorstelt een stel der uitgaven te zenden om ze te kunnen toonen en er bestellingen op te kunnen aannemen.

In verband met dit antwoord stelt de heer Nijhoff voor de toezending van 25 exemplaren der edita (zooals van de 3 laatste afleveringen der Bijdragen en van "de Groot's Kongsiwezen" plaats 
had) te staken, met verzoek hem een compleet stel der werken te doen toekomen om aan het verlangen der firma Kolff en Co. te voldoen.

$\mathrm{Na}$ eenige gedachtenwisseling wordt, overeenkomstig het voorstel van den Secretaris, besloten het getal der toe te zenden Bijdragen voortaan te beperken tot zes exemplaren, terwijl de Secretaris wordt gemachtigd, aan het verzoek van den heer Nijhoff om een compleet stel der werken van het Instituut, voor zooveel zulks nog doenlijk is, te voldoen.

Van Commissarissen te Batavia is ontvangen:

10. een schrijven dd. 10 Augustus jl., $\mathrm{L}^{\mathrm{a}} \mathrm{A}$, waarbij

$a$. wordt aangeboden een prima-wissel groot $f 303 \mathrm{~N}$. C., zijnde het bedrag van de tot en met Juli ll. ontvangen subsidie en contributiën over het loopende jaar;

$b$. de toetreding als lid van het Instituut wordt medegedeeld van den heer L. M. Vonck, aspirant-controleur te Tebing Tinggi (Palembang), met verzoek hem de uitgaven over het geheele jaar toe te zenden; en

c. wordt kennis gegeven, dat de heeren D. Grivel, laatstelijk te Padang Sidempoean en H. van Heuckelum, gep. assistent-resident, naar Nederland vertrokken, de contributie over het loopende jaar aan Commissarissen niet hebben voldaan;

20. een nader schrijven van den $27^{\mathrm{n}}$ Augustus jl., No. B, 130 , ten geleide van een secunda-wissel, groot $f 303 \mathrm{~N}$. C., waarvan de prima bereids was angeboden, en van een nieuwen prima-wissel, groot $f 505 \mathrm{~N}$. C., het bedrag der sedert ontvangen contributiën.

Tevens deelen zij mede, dat de heeren C. J. van Haastert, te Bandoeng en R. Brons Middel te Depok het lidmaatschap hebben aanvaard, met verzoek aan beide al de uitgaven over 1886 te willen doen toekomen; dat voorts het lid J. M. Rosskopf te Samarang met 1 Januari 1887 van de ledenlijst wenscht afgevoerd te worden, terwijl het adres van het lid N. Graafland voortaan is te Amboina, weshalve hij verzocht de uitgaven derwaarts te adresseeren.

De Secretaris wordt gemachtigd aan Commissarissen, onder dankbetuiging, den ontvangst te erkennen van de door hen toegezonden wissels, onder kennisgeving voorts dat van hunne mededeelingen en opgaven aanteekening is gehouden.

Ter tafel wordt gebracht een schrijven van den heer Gustaaf Winter, 
te Solo, van 27 Augustus jl., waarbij de vraag wordt geopperd, of het Instituut niet zou wenschen gebruik te maken van zijne bijdragen, bevattende beschrijvingen van zeden en gebruiken van het volk van Midden-Java met toelichtende plater. Schrijver geeft in overweging voor de honoraria der schriftelijke bijdragen de berekening te volgen van het Gouvernement, voorkomende in het Staatsblad van Ned.Indië en voor de af beeldingen die, welke doorgaans worden besteed voor illustraties in Nederland. De te maken kosten zullen, naar zijne meening, worden goed gemaakt door den verkoop van de geïllustreerde bijdragen, waarvan, voor zoover bekend, nog geen uitgave voorhanden is. Aangezien voorts drukwerk en lithographie in Nederland veel goedkooper en beter worden uitgevoerd dan in Indië, zou het tevens wenschelijk zijn, dat alles hier te lande werd bezorgd, hetgeen ook dit voordeel heeft, dat de uitgave dan geen vertraging behoeft te ondervinden.

$\mathrm{Na}$ gedachtenwisseling wordt besloten den Schrijver, onder dankzegging voor zijne aanbieding, mede te deelen:

10. dat, zoo er honorarium voor opstellen in de Bijdragen of voor afzonderlijke werken wordt verstrekt, dit in den regel $f 25$ per vel bedraagt, terwijl voor platen of illustratiën moeielijk honorarium kan worden berekend, daar de uitgave daarvan, wil zij althans eenige waarde hebben, reeds op zich zelve kostbaar is;

20. dat het Bestuur, alvorens het over de uitgave van bijdragen of werken met of zonder platen beslist, ze, overeenkomstig het Reglement, in handen stelt eener Commissie om verslag uit te brengen, of het aangeboden handschrift al dan niet geschikt is om vanwege het Instituut te worden uitgegeven, terwijl eveneens wordt gehandeld met stukken, waarvan de uitgave wordt voorgesteld met subsidie van het Instituut; en

30. dat het Bestuur, met het oog daarop, zich omtrent eene eventueele uitgave der aan te bieden bijdragen voorshands van eenige beslissing, welke dan ook, moet onthouden, doch den Schrijver uitnoodigt, om, mocht hij met de gestelde voorwaarden genoegen nemen, zijne opstellen ter kennisneming en beoordeeling over te zenden.

Van den heer H. J. Wansink, leeraar aan de Hoogere Burgerschool met vijfjarigen cursus te 's Gravenhage, is, onder dagteekening van 7 October jl., het volgend schrijven ingekomen:

"In den loop van dit jaar verscheen te Madrid een boek, het- 
welk tot titel heeft: "E] Archipiélago Filipino y las Islas Marianas, Carolinas y Palaos, su Historia, Geografía y Estadística par D. José Montero y Vidal." Van dit werk, hetwelk niet uitsluitend van een Spaansch belang, maar ook van groot gewicht voor onze koloniale wetenschap is, schreef de Hooggeleerde Heer Dr. Kern, hoogleeraar te Leiden, in het September-nummer van de Revue Coloniale internationale eene zeer gunstige recensie, eindigende met de volgende woorden :

"En conscience nous pouvons recommander la lecture de ce livre bien écrit et si plein de données précieuses. Il serait à désirer dans l'intérêt du public hollandais que quelqu'un de nos compatriotes entreprît la traduction, car la connaissance de la langue des Cervantes et des Calderon est malheureusement peu répandue chez nous. Une traduction hollandaise, fût-ce même en retranchant quelques sections, ne manquerait pas de stimuler la curiosité du public intelligent et engagerait peut-être quelques-uns de nos hommes officiels à une étude comparative de l'état politique, économique et moral des possessions néerlandaises et espagnoles dans les mers d'Asie, étude pleine de charme scientifique et d'intérêt actuel."

"Naar aanleiding dezer recensie heb ik mij de vrịheid veroorloofd prof. Kern te gaan spreken en Z.H.Gel. mede te deelen, dat ik wel bereid zou zijn eene Nederlandsche vertaling van dit boek te bewerken, indien ik vooraf de zekerheid hadde een uitgever te zullen vinden. Genoemde geleerde keurde mijn plan goed, oordeelde echter, dat bij het vele uitmuntende, hetwelk dit boek bevat, bij eene bewerking in het Nederlandsch, sommige hoofdstukken uitgelaten, andere uitgebreid moesten worden en verklaarde zich bereid tot die uitbreiding, welke dan als supplement bij het werk konde gevoegd worden. Prof. Kern meende, dat ook de Hooggeleerde Heer Dr. Wilken, hoogleeraar te Leiden, genegen zou zijn de behulpzame hand te bieden, en ried mij aan mij ook tot prof. W. te wenden, hetgeen ik gedaan heb met het gunstige gevolg, dat ook deze geleerde mijn plan goedvond en zijne gewaardeerde hulp toezeide. Door een aanhangsel van de hand van mannen als de twee genoemde hoogleeraren wordt de waarde van het werk voor Nederland aanzienlijk verhoogd, en meen $\mathrm{ik}$, dat het misschien wel op den weg des Bestuurs van het Koninklijk Instituut voor de taal-, land- en volkenkunde van Nederl. Indië kan liggen eene Nederlandsche bewerking van het boek uit te geven, en geef ik mij dientengevolge de eer mij tot voornoemd Bestuur te wenden met de vraag of het 
tot die uitgaaf bereid is. Bij ontvangen gunstig antwoord op mijne vraag, zal ik mij gaarne tot nader overleg ter beschikking van het Bestuur stellen."

$\mathrm{Na}$ eenige beraadslaging wordt, overeenkomstig het voorstel van den Voorzitter, besloten dit schrijven om bericht en raad in handen te stellen van den hoogleeraar Kern.

Niets meer hierna aan de orde zijnde, wordt de Vergadering door den Voorzitter gesloten.

\section{7sTE BESTUURSVERGADERING}

GEHOUDEN 20 NOVEMBER 1886.

Tegenwoordig de hh. van Rappard (Voorzitter), van Deventer (Onder-voorzitter), J. H. de Groot (Penningmeester), Matthes, Kielstra, Snouck Hurgronje, Wilken, Juynboll, Niemann, Riedel en Wijnmalen (Secretaris). Afwezig de hh. Robidé van der Aa en Schlegel.

De notulen van het verhandelde in de vorige Vergadering worden gelezen en goedgekeurd.

Door den Bibliothecaris wordt mededeeling gedaan van de ingekomen boekwerken, waarbij hij tevens den ontvangst bericht van :

10. het levensbericht van den heer de Bruijn, door het medelid E. B. Kielstra, een overdruk in $4^{0}$, uit het Tijdschrift van het Koninklijk Instituut van Ingenieurs;

20. een viertal nos van de Nieuwe Rotterdamsche Courant, door het medelid Dr. Snouck Hurgronje toegezonden, waarin zijne artikelen over het zevende Orientalisten-Congres te Weenen en over Sèjjid Othmân ibn Jahja el Mawi, een Arabisch bondgenoot der Nederlandsch-Indische Regeering"; terwijl de Secretaris daarbij nog een exemplaar overlegt van de Munchener Allgemeine Zeitung van Woensdag 13 October jl., waarin zoowel een uitvoerig overzicht van de door Dr. Snouck Hurgronje op het Weener-congres gehouden 5e Volgr. II. 
voordracht als eene "biographische Notiz" omtrent ons medelid is opgenomen ;

30. eene missive van de Koninklijke Akademie van Wetenschappen te Amsterdam, houdende dankbetuiging voor de gezonden Bijdragen, $5^{\circ}$ Reeks, deel I, afl. 2, en tevens ten geleide van de laatst verschenen uitgaven der Akademie;

40. eene missive van het Ministerie van Binnenlandsche Zaken, dd. 25 October jl., $\mathrm{L}_{\mathrm{a}}$. A, afd. K. W., ten geleide van acht pakketten met boeken ontvangen van de Fransche Commissie voor internationale ruilingen te Parijs;

50. eene missive van den heer A. Kappler, te Stuttgart, van 18 October jl., ten geleide van zijn onlangs verschenen werk: "Surinam mit bezug auf Kolonisation";

60. eene missive van de Directie van het Musée Guimet, te Lyon, houdende aankondiging van de toezending zoowel van de Annales du Musée Guimet, T. IX, als van de Revue de l'Histoire des religions, T. XIV, $\mathrm{n}^{\mathrm{o}} .1$;

70. eene missive van het medelid dr. D. R. Capriles, te Curaçao, van 8 October jl., houdende mededeeling, dat het hem is gelukt eene geheele volledige verzameling te verkrijgen van de Curaçaosche Courant, 30 jaargangen, van 1857 tot en met 1886, welke hij, in 2 kisten gepakt, per stoomschip Prins Maurits heeft verzonden ten geschenke voor de Bibliotheek van het Instituut.

Wordt besloten de boekwerken te plaatsen in de Bibliotheek, onder dankzegging aan de gevers.

Verder zijn ontvangen:

$1^{\circ}$. eene missive van the Straits Branch of the Royal Asiatic Society, te Singapore, houdende verzoek om toezending van enkele ontbrekende afleveringen van de Bijdragen, en wel van 1878, 2。 stuk, tweede deel, en 1880 , le en 2 e stuk, vierde deel.

Den Secretaris wordt opgedragen, zoo mogelijk, aan het verzoek te voldoen.

20. eene missive van Mevrouw de Wed. de Hollander-Holms, houdende kennisgeving van het overlijden van Dr. J. J. de Hollander, oud-hoogleeraar te Breda.

30. missives van de h. T. van Alphen, P. van der Crab, D. G. E. Wolterbeek Muller en G. de Wijs, allen houdende verzoek met den 
aanvang van het volgend jaar hunne namen van de ledenlijst af te voeren.

40. eene missive van den hoogleeraar H. C. Dibbits, te Utrecht, waarbij, op verzoek van Mevrouw de Wed. Lasonder, wordt medegedeeld, dat, tengevolge van het overlijden van haren echtgenoot, Prof. dr. E. H. Lasonder, diens lidmaatschap van het Instituut is vervallen.

50. missives van de hh. J. W. IJzerman en S. W. Tromp, te 's Gravenhage, beide houdende kennisgeving van de aanvaarding van het lidmaatschap van het Instituut.

De missives, sub $20-5^{0}$, worden voor kennisgeving aangenomen.

Op voorstel van den heer Wilken wordt tot lid benoemd de heer M. Buijs , predikant der Hervormde gemeente, onlangs naar Indië teruggekeerd, van welke benoeming aan Commissarissen mededeeling zal geschieden.

Van Commissarissen te Batavia zijn ontvangen:

a. twee briefkaarten ter mededeeling, dat de hh. W. L. Troostenburg de Bruijn te Soepajang (Sumatra's Westkust) en J. W. Stemfoort, te Kota Radja (Atjeh) als leden zijn toegetreden, met verzoek dat aan hen de uitgaven over het geheele jaar 1886 worden toegezonden;

b. eene missive, dd. 11 October jl. no. B/131, waarbij

1. aangeboden wordt een prima wissel groot $f 706.76 \mathrm{~N}$. C., betaalbaar drie maanden na dato bij de heeren A. van Hoboken en Co. te Rotterdam, daarmede overmakende de sedert ontvangen contributiën en subsidie;

2o. bericht wordt, dat door de heeren Meiss te Bondowosso en Joekes, te Martapoera, het lidmaatschap is aanvaard, wat den laatste betreft, ingaande met het 2 e halfjaar van 1886 , zoodat aan hem slechts de in dat tijdvak verschenen edita zullen behooren te worden gezonden, terwijl de eerste die over het geheele jaar dient te ontvangen; terwijl, eindelijk,

3o. wordt medegedeeld dat het lid P. Jansz voor de boekerij van het Instituut ten geschenke heeft aangeboden een exemplaar van eene vertaling in het Javaansch van het Evangelie van Lucas, bewerkt op last van het Britsch-Buitenlandsch Bijbelgenootschap, waarvoor hem reeds dank is gezegd. 
Naar aanleiding dezer mededeelingen van Commissarissen wordt, overeenkomstig het voorstel van den Secretaris, besloten, den ontvangst van den toegezonden wissel te erkennen, met bericht dat van hunne verdere mededeelingen aanteekening zal worden gehouden.

Ter tafel wordt gebracht eene missive van den Minister van Koloniën van 16 October jl., Lett. A ${ }^{\mathrm{I}}$. no. 7, waarbij, ter voldoening aan het dezerzijds gedaan verzoek van den $11^{\mathrm{n}}$ Oct. te voren, no. 71, vertrouwelijke mededeeling wordt gedaan van den brief van den Gouverneur-Generaal van Ned. Indië, dd. 27 Juli jl. Lett. C, $\mathrm{n}^{\circ}$. 194/2 en bijlagen, welke stukken handelen omtrent eene wetenschappelijke zending naar Hadramaut en na gemaakt gebruik worden terug verlangd.

Van een en ander wordt door de Vergadering kennis genomen, alsmede van eene omtrent het bedoelde onderwerp door den hoogleeraar M. J. de Goeje ingediende uitvoerige nota.

$\mathrm{Na}$ gedachtenwisseling wordt besloten:

1o. de vanwege het Ministerie van Koloniën ter vertrouwelijke kennisneming ontvangen stukken, onder dankzegging, terug te zenden; en

20. den heer de Goeje mede te deelen dat de Vergadering zich eene nadere beslissing omtrent de voorgenomen zending naar Hadramaut voorbehoudt, onder aanbeveling haar te zijner tijd de nadere inlichtingen te willen verstrekken, welke door hem bij belanghebbenden zijn gevraagd.

De Secretaris deelt het advies mede, dat, op verzoek van het Bestuur, door den hoogleeraar Kern bij zijn schrijven van den 23en October jl. is uitgebracht omtrent het bewerken en uitgeven eener vertaling van het spaansche werk van D. José Montero y Vidal, getiteld: "El Archipiélago Filipino y las Islas Marianas, Carolinas y Palaos, su Historia, Geografia y Estadistica ", naar aanleiding van een aan het Bestuur van het Instituut gericht schrijven van den heer W. J. Wansink, in de vorige Vergadering ter tafel gebracht.

$\mathrm{Na}$ gedachtenwisseling vereenigt de Vergadering zich eenparig met het advies des heeren Kern, strekkende, om zich in de eerste plaats te vergewissen of er een uitgever te vinden is, bereid om in overleg met den heer Wansink de vertaling van Montero's boek te drukken; waarna men verder eenige leden van het Instituut ver- 
zoeken moet hun steun bij de omwerking van het boek te verleenen, om, eindelijk, de uitgave onder het toezicht van het Instituut te doen geschieden, waardoor men zich tot het Departement van Koloniën zou kunnen wenden om te trachten aan den ondernemenden uitgever den geldelijken steun van het Departement te verzekeren.

Door den Secretaris is om bericht en raad in handen van den heer Wilken gesteld een ter plaatsing in de Bijdragen aangeboden opstel van den heer S. W. Tromp, bevattende "Eenige mededeelingen omtrent de Boegineezen van Koetei."

Overeenkomstig het praeadvies des heeren Wilken besluit de Vergadering het opstel in de eerstvolgende aflevering der Bijdragen te doen opnemen.

Namens het lid Graafland, te Tandjong Pinang, wordt door den heer Niemann ter plaatsing in de Bijdragen aangeboden eene door hem bewerkte "Schets van de Chineesche vestigingen in de afdeeling Karimon". Om bericht en raad in handen gesteld van den heer Schlegel.

Ingevolge de bepalingen van het Huishoudelijk Reglement dient de Penningmeester een ontwerp in zijner begrooting voor het volgend dienstjaar 1887, waaraan hij eenige mededeelingen vastknoopt omtrent den finantieëlen toestand van het Instituut, die niet ongunstig blijkt te zijn.

Onder dankbetuiging aan den Penningmeester, wordt besloten zijne concept-begrooting aan de leden ter kennisneming toe te zenden en ter verdere behandeling in de eerstvolgende Vergadering.

De heer Snouck Hurgronje doet der Vergadering eenige mededeelingen omtrent de voorgenomen uitgave van zijn werk en vraagt haar advies over de taal, waarin het moet worden bewerkt. $\mathrm{Na}$ eenige gedachtenwisseling wordt besloten de keuze der taal aan den heer Snouck Hurgronje over te laten.

Verder deelt de heer Snouck Hurgronje mede, dat hij, geheel afgescheiden van zijn omvangrijken arbeid, gelegenheid heeft eenige kleine monographiën te leveren, o. a. eene schets van het onderwijs in de geloofsleer, eene geschiedenis der dogmen of het onderwijs in Indië, enz. Hij vraagt of zij in de Bijdragen, dan wel elders opgenomen zouden kunnen worden. Eenparig is de Vergadering van 
oordeel daarvoor het tijdschrift van het Institunt aan te bevelen.

De Secretaris bespreekt den inhoud van de eerstvolgende aflevering der Bijdragen, welke in Januari a. s. zal moeten verschijnen. Wordt goedgekeurd daarin, behalve het levensbericht van Prof. Meinsma door Prof. Vreede en het opstel des heeren S. W. Tromp over de Boegineezen van Koetei, de bijdrage over Sumatra's Westkust van den heer Kielstra, zoo mogelijk in haar geheel, op te nemen, met 't oog vooral op de voor de volgende afleveringen toegezegde opstellen der heeren Tiele en Wilken.

Niets meer hierna aan de orde zijnde, wordt de Vergadering door den Voorzitter gesloten.

\section{STE BESTUURSVERGADERING}

GEHOUDEN 13 DECEMBER 1886.

Tegenwoordig de heeren van Rappard (Voorzitter), J. H. de Groot (Penningmeester), Matthes, Riedel, Schlegel, Snouck Hurgronje, Wilken, Niemann, Juynboll en Wijnmalen (Secretaris). Afwezig, met kennisgeving, de heeren Robidé van der Aa, van Deventer en Kielstra.

De notulen van het verhandelde in de vorige Vergadering worden gelezen en goedgekeurd.

Mededeeling wordt gedaan van den ontvangst en aankoop van verschillende werken en tijdschriften, waarbij tevens wordt voorgelezen :

10. een schrijven van den Secretaris van het Württembergischer Verein für Handelsgeographie etc., te Stuttgart, ten geleide van de in de verzameling van het Instituut ontbrekende Io en $\amalg$ e Jahresberichten van evengemeld Verein; en

20. een schrijven van het medelid P. M. Netscher, te 's Gravenhage, ten geleide van twee afleveringen van het Tijdschrift uitge- 
geven door het Archaeologisch en Geographisch Instituut van Pernambuco. Het eerste nummer van Juni jl. bevat het verslag, in eene buitengewone vergadering van dat Genootschap op 9 Mei te Recife uitgebracht, door Don José Hygino Duarte Pereira over de door hem in het Rijksarchief alhier met zooveel volharding gedane navorschingen betreffende de geschiedenis van Brazilië in de 17e eeuw, toen de Nederlanders aldaar gevestigd waren. In het tweede nommer, van Oct. jl., vindt men de vertaling, in 't Portugeesch, van sommige der belangrijkste door hem gevonden oude Hollandsche documenten.

Namens den heer Don Duarte Pereira, die er prijs op stelde dat die beide stukken ook in de boekerij van het Kon. Instituut worden opgenomen, biedt de heer Netscher ze tot dat doel aan.

Plaatsing der ontvangen werken in de Bibliotheek, onder dankbetuiging aan de inzenders.

De Voorzitter bericht dat zijn ingekomen:

10. eene missive van de Directie van het Musée Guimet, van 15 December jl., houdende mededeeling, dat die instelling van Lyon naar Parijs is overgebracht, ten gevolge waarvan alle inzendingen van boeken of andere voorwerpen behooren te geschieden aan het adres: 30, Avenue du Trocadéro. Hiervan zal aanteekening worden gehouden.

2o. eene missive van de heeren Angelo de Gubernatis e. a., te Florence, houdende mededeeling van de oprichting, aldaar, van eene Société Asiatique Italienne, met verzoek aan de daarbij gevoegde statuten eenige aandacht te wijden en tot het nieuwe Genootschap als lid toe te treden.

Wordt besloten te antwoorden, dat met belangstelling van de oprichting der zusterinstelling is kennis genomen, terwijl men gaarne te zijner tijd in eene ruiling van wederzijdsche uitgaven zal treden.

3o. eene circulaire van den Vlaamschén vooruitstrevenden Studentenkring, te Brussel, waarbij de hulp der Nederlandsche Taalbroeders in het algemeen en ook van het Instituut in het bijzonder wordt ingeroepen om de bibliotheek, verbonden aan de Vrije Hoogeschool te Brussel, en onlangs door een zwaren brand bijna geheel vernietigd, in een nog schitterender staat dan vroeger te herstellen, meer bepaald met betrekking tot de eens zoo rijke verzameling van nederlandsche werken. 
$\mathrm{Na}$ eenige gedachtenwisseling wordt, overeenkomstig het voorstel van den Voorzitter, besloten den Secretaris te machtigen aan het gedaan verzoek te voldoen door toezending, zoo mogelijk, van een exemplaar van de werken van het Instituut.

40. eene missive van den heer B. W. Wttewaall van Wickerburgh, te Utrecht, houdende mededeeling, dat onder zijne berusting zijn twee handschriften betreffende Sumatra, blijkbaar met dezelfde hand geschreven, waarvan het eerste bevat "de radicale beschrijving van Sumatra's Westkust, ao. 1761, door H. van Bazel", meerendeels reeds uitgegeven in het Tijdschrift voor Ned.-Indië, deel IX, blz. 1-92, en in Sloet's Tijdschrift van Staathuishoudkunde en Statistiek, deel XIII, terwijl het andere eene "beschrijving" geeft "van Sumatra's Westcuste, met eene corte verdeeling van het Eiland Sumatra". Mocht men van het laatstgenoemde handschrift kennis willen nemen, gaarne zoude het ter inzage worden aangeboden, ook ter beoordeeling of het $n u$ nog zooveel historische waarde heeft om te worden bekend gemaakt.

Overeenkomstig het voorstel van den Secretaris wordt besloten, onder dankzegging voor de betoonde belangstelling, van het aanbod tot overzending van het bedoelde handschrift gebruik te maken, en het, na ontvangst, om consideratiën en advies te stellen in handen van de heeren van Deventer en Kielstra.

$5_{\text {o. }}$ eene missive van Commissarissen van 16 November ll., houdende kennisgeving dat het lid $\mathrm{mr}$. Arriëns te Batavia verzocht heeft van de ledenlijst te worden afgevoerd, ingaande met ultimo December van het loopende jaar.

Hiervan zal aanteekening worden gehouden.

De Secretaris herinnert dat hij met den hoogleeraar Juynboll in de Bestuursvergadering van 14 November 1885 in commissie benoemd is geworden om advies uit te brengen omtrent een van Commissarissen ontvangen schrijven van den $5^{\text {en }}$ October 1885, B/119, waaarbij zij verzoeken dat het Instituut, evenals het Bataviaasch Genootschap van Kunsten en Wetenschappen, op de een of andere wijze zijn oordeel doe kennen omtrent het besluit der Regeering van Nederlandsch-Indië om voorshands af te zien van het nemen van bijzondere maatregelen om het verval der Hindoe-oudheden in MiddenJava te voorkomen. 
Ter voorlichting van de Commissie hebben Commissarissen in een nader schrijven medegedeeld, dat het Bestuur van het Bataviaasch Genootschap zich reeds bij missive van 23 Juni 1883 (Not. '83, blz. 72) door tusschenkomst van den Directeur van Onderwijs, Eeredienst en Nijverheid tot de Regeering had gewend met verzoek aan den heer Groeneveldt de opdracht te doen een onderzoek in te stellen naar de oudheden van Midden-Java en voorstellen in te dienen tot instandhouding van die oudheden. Van zijne bevinding werd aan de Regeering verslag gedaan (Not. '84, blz. 17) en zijn rapport om consideratie en advies in handen van het Genootschap gesteld. Daarop werd in 1885 aan de Directie van Onderwijs, Eeredienst en Nijverheid door de Regeering medegedeeld, dat zij voorloopig meende te moeten afzien van het nemen van maatregelen, enz., eene mededeeling waarvan kennis werd gegeven aan 's Genootschaps's Directie door het betrokken Departement. Naar aanleiding daarvan heeft het Bestuur van het Genootschap aan de Regeering geschreven (zie Notulen ' 85 , blz. 1227), het eenige wat door dat Bestuur in den stand der zaak nog kon worden gedaan.

$\mathrm{Na}$ mededeeling van een en ander meent de Commissie als haar advies te mogen uitspreken: dat zij zich geheel vereenigt met het gevoelen, in het schrijven van Commissarissen van 8 October 1885 geuit, zoowel wat het doel betreft, als de wijze waarop het is te bereiken. Kunnen er geen gelden beschikbaar worden gesteld tot onderhoud van de aanwezige monumenten, in elk geval zouden er toch maatregelen kunnen en moeten genomen worden, waardoor de plunderlust van Javaansche oudheden wordt beteugeld. Welke stappen echter vanwege het Instituut in deze moeten worden gedaan, daaromtrent wenscht de Commissie vooralsnog geen advies uit te brengen, doch stelt zij voor de behandeling van dit onderwerp te verdagen, met het oog vooral ook op hetgeen thans ten aanzien der Hindoe-oudheden in Midden-Java wordt verricht en de voorstellen, die daaromtrent eerlang ook aan het Instituut zullen worden gedaan.

Eenparig vereenigt de Vergadering zich met dit advies.

Door den Secretaris wordt, met ondersteuning der heeren Matthes en Niemann, der Vergadering in overweging gegeven vanwege het Instituut een herdruk te bezorgen van het in 1864 door de zorgen van het Ned. Bijbelgenootschap te Amsterdam uitgegeven eerste deel van de door Dr. Matthes bewerkte, uit oorspronkelijke Boegineesche stukken bestaande Chrestomathie, waarvan 
de oplaag, op eenige weinige exemplaren na, geheel is uitgeput.

Het werk zou bij den herdruk, naar de gebleken behoeften, gewijzigd, met vele nieuwe stukken vermeerderd worden, en, evenals vroeger de Makassaarsche Chrestomathie, wat den tekst betreft, in enkele deeltjes gesplitst worden, terwijl tevens aan den herdruk meer zorg zou kunnen besteed worden dan zulks kon plaats hebben bij de eerste uitgave, die met zeer gebrekkige hulpmiddelen, nu vóor ruim 20 jaren, te Makassar werd bezorgd.

Daar evenwel aan den herdruk aanzienlijke kosten verbonden zijn, wordt tevens in overweging gegeven om, alvorens tot dien herdruk te besluiten, te trachten van het Departement van Koloniën eene subsidie tot een bedrag van hoogstens $f 3000$ te verkrijgen en zich daartoe bij adres tot den Minister te wenden.

$\mathrm{Na}$ eenige gedachtenwisseling wordt, overeenkomstig het gedane voorstel, besloten.

De Secretaris brengt ter tafel een door hem van Mr. C. M. Dozy, Archivaris te Leiden, ontvangen opstel over Abel Janszoon Tasman. Geput uit dusver niet geraadpleegde bronnen, waardoor het menige niet onbelangrijke bijzonderheid omtrent den ontdekker van Australië aan het licht brengt, verdient het eene plaats in de Bijdragen van het Instituut; en de Secretaris zou ook daartoe adviseeren, ware het niet dat de Schrijver het verzoek had gedaan bij plaatsing van zijne bijdrage het gewone honorarium te willen verhoogen, waartegen $\mathrm{z}$. i. bezwaren bestaan.

Met het oog op de moeielijkheid om van den aangenomen regel af te wijken, stelt de Secretaris voor den Schrijver in overweging te geven zijn opstel tegen het vastgestelde honorarium voor de Bijdragen te willen afstaan. Dienovereenkomstig wordt besloten.

Door de hh. Niemann en Wilken wordt rapport uitgebracht over de in hunne handen gestelde Oeloesch-nederlandsche en Nederlandschoeloesche woordenlijsten, door het lid Harrebomée ingezonden. Hun advies strekt om, vooreerst, terug te komen op het vroeger genomen besluit tot uitgave van de Nederlandsch-oeloesche woordenlijst, daar zij niet die waarde bezit als de Oeloesch-nederlandsche; en, ten anderen, deze laatste in de Bijdragen op te nemen, benevens de daarbij gevoegde korte volzinnen, met dien verstande evenwel, dat 10. vooraf door den auteur eenige ophelderingen worden verstrekt omtrent de door hem gevolgde wijze van transscriptie; 20. inlichtingen gegeven 
omtrent land en volk waar de door den Schrijver behandelde taal wordt gesproken; en eindelijk $3{ }^{\circ}$. omtrent een aantal woorden eenige nadere verklaring aangeboden, een en ander in overleg met den rapporteur, den heer Niemann, die zich bereid verklaart daartoe met den heer Harrebomée van gedachten te wisselen.

Daar niemand over dit praeadvies het woord verlangt, wordt dienovereenkomstig besloten, onder dankzegging wijders aan de Commissie voor haar arbeid.

Door den heer Schlegel wordt rapport uitgebracht omtrent de in de vorige Vergadering in zijne handen gestelde bijdrage des heeren Graafland over de Chineesche vestigingen in de afdeeling Karimon. Het advies strekt tot opneming der bijdrage, met de daarbij gevoegde kaart, in een der eerstvolgende afleveringen van het Tijdschrift, terwijl, zoo mogelijk, aan den Schrijver zal worden in overweging gegeven de door hem aangehaalde plaatsnamen alsnog met Chineesche karakters aan te duiden.

Dienovereenkomstig wordt besloten.

De Secretaris oppert het denkbeeld om de Notulen van de Bestuursen Algemeene Vergaderingen, welke thans een goed deel van het tijdschrift innemen, voortaan ééns in het jaar, telkens nà de Algemeene jaarlijksche Vergadering afzonderlijk uit te geven tegelijk met de April-aflevering.

$\mathrm{Na}$ eenige gedachtenwisseling wordt het door de meerderheid der Vergadering onraadzaam geacht van de dusver gevolgde wijze van publiceering der Notulen af te wijken.

Ingevolge eene hem als bestuurslid van het Indisch Genootschap gegeven opdracht vestigt de Secretaris de aandacht op de gebrekkige ventileering van de lokalen, waarin op doeltreffende wijze moet worden voorzien. Overeenkomstig het vporstel van den Voorzitter wordt besloten, den Penningmeester op te dragen het noodige te doen verrichten tot het verkrijgen van een deugdelijk ventilatie-toestel.

Onder herinnering, dat het contract met de Haagsche Brandverzekering-maatschappij ingevolge vroeger genomen besluit met ult. December a. s. vervalt, vraagt en erlangt de Penningmeester machtiging een nieuw verzekerings-contract te sluiten met de Belgische Vereeniging Union, waarvan de heeren van Prehn en Co. hier ter 
stede agenten zijn, met bepaling dat de verzekerde som zal bedragen $f 45,000$, tegen eene premie van $f 33.45$.

Aan de orde is de vaststelling der begrooting voor het dienstjaar 1887, welke bereids bij al de Bestuursleden in rondlezing is geweest.

De Voorzitter stelt voor, art. 12, aanwijzende de bestrijding der kosten van het Secretariaat-Bibliothecariaat, dusver uitgetrokken tot een bedrag van $f 100$, te verhoogen met $f 400$, en alzoo te brengen op $f 500$, met bepaling dat die post zal worden omschreven: "Kosten van Secretariaat en Bibliothecariaat, met inbegrip van de kosten van de Redactie der Bijdragen".

$\mathrm{Na}$ toelichting van den Voorzitter vereenigt de Vergadering zich eenparig met dit voorstel, ten gevolge waarvan het vermoedelijk batig saldo wordt geraamd tot een bedrag van $f \mathrm{l} 35.97$.

Aldus gewijzigd, wordt de begrooting, aanwijzende voor de ontvangsten $f 6809$. - en de uitgaven $f 6673.03$, met een vermoedelijk batig saldo van $f 135.97$, in omvraag gebracht en met algemeene stemmen goedgekeurd, waarna de Voorzitter den Penningmeester dank zegt voor de zorg, door hem aan zijn arbeid besteed.

Op voorstel van den heer Snouck Hurgronje worden tot leden van het Instituut benoemd de heeren P. N. van der Chijs, ViceConsul der Nederlanden, Consul van Zweden en Noorwegen te Djidda en J. H. Lieftinck, makelaar in tabak, te Amsterdam.

De heer Schlegel herinnert der Vergadering aan de missie des heeren Dr. J. J. M. de Groot in China en vraagt, of er geene mogelijkheid zou bestaan om hem voor zijne ethnographische onderzoekingen een subsidie toe te kennen tot een bedrag van $f 1000$.

Met het oog op het vergevorderd uur wordt de behandeling dezer zaak, overeenkomstig het voorstel van den Voorzitter, uitgesteld, waarna de Vergadering wordt gesloten. 


\section{9ste BESTUURSVERGADERING}

GEHOUDEN 15 JANUARI 1887.

Tegenwoordig de heeren van Rappard (Voorzitter), van Deventer (Ondervoorzitter), J. H. de Groot (Penningmeester), Kielstra, Matthes, Schlegel, Snouck Hurgronje, Wilken en Wijnmalen (Secretaris). Afwezig, met kennisgeving, de heeren Robidé van der Aa, Juynboll, Nieman en Riedel.

De notulen van het verhandelde in de vorige Vergadering worden gelezen en goedgekeurd.

Nadat der Vergadering door den Bibliothecaris opgave gedaan en inzage verleend was van de sedert de vorige bijeenkomst ontvangen boekwerken, wordt medegedeeld :

10. een briefkaart van Commissarissen, houdende bericht dat het lid, de heer H. M. Andrée Wiltens te Batavia, verzocht heeft met ulto. December 1886 van de ledenlijst te worden afgevoerd.

20. eene missive van den heer J. Baert de la Faille, te 's Hage, dd. 30 December 1886 , waarbij de wensch wordt te kennen gegeven, om van 1 Januari 1887 niet meer te worden beschouwd als lid van het Instituut.

40. eene missive van de Sociedad Mexicana de geografia y estadistica, te Mexico, waarbij bericht wordt dat zij wegens verschillende omstandigheden sedert de uitgave der 3 afleveringen van deel VI van het "Boletin" geene verdere stukken heeft uitgegeven, onder mededeeling wijders van de samenstelling van het Bestuur van het Genootschap.

$\mathrm{Al}$ deze missives worden voor kennisgeving aangenomen.

De Secretaris deelt mede, dat hij van den heer B. W. Wittewaall van Wickerburgh te Utreeht, het handschrift betreffende de Westkust van Sumatra, waaromtrent hij in de vorige Vergadering had gesproken, ter inzage had bekomen. Overeenkomstig het vroeger reeds 
genomen besluit in handen gesteld van de heeren van Deventer en Kielstra.

Ter tafel wordt gebracht een schrijven van den Minister van Koloniën, van den 29 December 1886 , Titt. AI, no. 48, waarbij, in antwoord op een brief dezerzijds van den 20 December te voren, no. 84, wordt medegedeeld, dat er geen termen zijn om een subsidie uit 's lands kas te verleenen voor de uitgaaf van eene Nederlandsche bewerking van het Spaansche werk van Montero y Vidal over de Philippijnen, terwijl de Minister, naar aanleiding van het gedaan aanbod, er op rekent dat van dit besluit vanwege het Instituut aan de firma Brill te Leiden kennis zal worden gegeven, zoodat de Minister haar geen beschikking op haar verzoekschrift behoeft te doen toekomen.

De Secretaris geeft te kennen, dat hij onverwijld van 's Ministers beslissing aan de firma Brill bericht heeft gezonden, met verzoek tevens van haar te mogen vernemen, of zij, nu de bedoelde subsidie van regeeringswege niet is verleend, ook bereid is de uitgave van meergemeld werk te hezorgen. Daar de Secretaris hierop nog geen antwoord heeft ontvangen, stelt hij voor de behandeling der vraag, of het Instituut de taak der Hollandsche bewerking en uitgave van Montero y Vidal's werk met of zonder subsidie zal op zich nemen, tot eene volgende Vergadering te verdagen. Dienovereenkomstig wordt besloten.

De Secretaris, teveus Bibliothecaris, bespreekt de belangen der aan zijne zorg toevertrouwde Bibliotheken van het Instituut en het Indisch Genootschap, vooral ook met het oog op de voorgenomen uitgave van den Catalogus der boekverzameling van eerstgenoemde instelling, welke nagenoeg voor de pers gereed is, terwijl het te verwachten is, dat ook eene geheel nieuwe uitgave van den inventaris van den boekenschat van het Indisch Genootschap weldra zal worden voorgesteld. Naar aanleiding hiervan wordt de vraag geopperd, of de tot dusver volgehouden scheiding der Bibliotheken moet worden gehandhaafd, dan wel of het niet wenschelijk zou zijn, dat er eene vereeniging der beide verzamelingen tot éene Koloniale Bibliotheek tot stand kwam onder nader vast te stellen bepalingen en voorwaarden. $\mathrm{Na}$ langdurige beraadslagingen wordt besloten, deze zaak tot een onderwerp van een nauwgezet onderzoek te maken en een commissie te benoemen, met opdracht, om met twee vanwege het Bestuur van het Indisch Genootschap daartoe aan te wijzen leden in overleg 
te treden en te zijner tijd der Vergadering van consideratiën en advies te dienen.

Tot leden der Commissie vanwege het Instituutsbestuur worden benoemd de heeren $\mathrm{J}$ H. de Groot, Kielstra en de Secretaris, terwijl laatstgenoemde wordt gemachtigd het Bestuur van het Indisch Genootschap van een en ander in kennis te stellen, met verzoek twee zijner leden aan te wijzen, die deel zouden kunnen uitmaken van de gemengde Commissie tot onderzoek der geopperde vraag.

De heer Schlegel komt nader terug op het in de vorige Vergadering door hem behandelde onderwerp: het verleenen van subsidie aan den heer Dr. J. J. M. de Groot voor zijne wetenschappelijke zending in China. Met het oog op het hooge belang en de te verwachten resultaten dier zeuding, welke wèl door de Indische Regeering ondersteud wordt, doch niet in die mate als noodig en wenschelijk wordt geacht, dringt Spreker er op aan, dat het Instituut den heer de Groot alsnog eene tegemoetkoming verleene tot een bedrag van $f 1000$.

$\mathrm{Na}$ gedachtenwisseling verklaart de meerderheid der Vergadering zich voor dit voorstel; doch omtrent de vraag, op welke wijze de som ter kwijting dier subsidie moet worden gevonden, loopen de meeningen uit een; terwijl ter eenre zij het denkbeeld wordt geopperd het gebouw met eene hypotheek te bezwaren tot een bedrag hooger dan de benoodigde som, waardoor tevens meer beschikbaar kasgeld zou aanwezig zijn, wordt van den anderen kant de wensch geuit zooveel doenlijk te trachten de som te bestrijden uit de gelden van het gewone dienstjaar, en, zoo die niet toereikend of dadelijk beschikbaar mochten zijn, alsdan eene onderhandsche leening te sluiten, terwijl de voorsteller, de heer Schlegel, zich bereid verklaart om, ingeval men tot het aangaan eener leening mocht overgaan, alsdan het bedrag daarvoor beschikbaar te stellen.

Eenparig vereenigt de Vergadering zich met het laatst verdedigde gevoelen, ten gevolge waarvan wordt goedgekeurd aan de a. s. Algemeene Vergadering, ingevolge art. 10 van het Reglement machtiging te vragen tot het aangaan der leening.

Onder herinnering, dat de volgende Bestuursvergadering zal moeten gehouden worden op den $19_{\mathrm{n}}$ Februari a. s., den dag waarop 's Konings $70 \mathrm{e}$ verjaardag zal worden gevierd, stelt de Secretaris voor de vergadering eene week te vervroegen, en haar mitsdien te stellen 
op Zaterdag, den 12en Febr., met bepaling tevens dat de Algemeene Vergadering zal gehouden worden op den $26^{\mathrm{n}}$ daaraanvolgende.

Dienovereenkomstig wordt besloten.

De Penningmeester deelt mede, dat de rekening en verantwoording over het afgeloopen dienstjaar gereed is, waarom hij verzoekt dat zij door eene Commissie uit het Bestuur worde nagezien. Tot leden dier Commissie worden vervolgens aangewezen de hh. van Deventer en Kielstra, met opdracht in de volgende vergadering van hunne bevinding verslag uit te brengen.

Namens den heer Tromp deelt de Secretaris mede, dat dit medelid voor de eerstvolgende aflevering der Bijdragen een opstel met toevoeging van eenige platen zal gereed maken, meer bepaald handelende over verschillende toestanden in Koetei. Wordt besloten, om, zoodra het stuk in zijne handen zal zijn gekomen, het om bericht en raad te zenden aan de hh. Wilken en Snouck Hurgronje.

Niets meer hierna aan de orde zijnde, wordt de Vergadering door den Voorzitter gesloten.

\section{0sTE BESTUURSVERGADERING}

GEHOUDEN 12 FEBRUARI 1887.

Tegenwoordig de hh. van Rappard (Voorzitter), van Deventer (Onder-voorzitter), J. H. de Groot (Penningmeester), Matthes, Schlegel, Snouck Hurgronje, Wilken, Riedel, Niemann, Kielstra en Wijnmalen (Secretaris).

$\mathrm{Na}$ opening der Vergadering deelt de Voorzitter mede, dat is ingekomen een schrijven van Mevr. de Wed. Juynboll-Schadee, houdende kennisgeving van het overlijden van haren echtgenoot, Prof. Dr. A. W. T. Juynboll, te Delft, terwijl kort daarop het bericht werd ontvangen, dat ook het bestuurslid P. J. B. C. Robidé van der Aa aan het Instituut door den dood ontvalien is. Aan beider verdiensten wijdt de Voorzitter een woord van hulde, en vertrouwt hij dat hunne nagedachtenis bij het Instituut in eere zal worden gehouden. 
Overeenkomstig het voorstel des Voorzitters wordt besloten de kennisgave van Mevr. de Wed. Juynboll te beantwoorden met een brief van rouwbeklag; en waar bij de begrafenis van Prof. Juynboll het Instituut vertegenwoordigd was door eene Commissie, bestannde uit de hh. de Groot en Wijnmalen, wordt dezelfde Commissie nitgenoodigd ook aan wijlen het Bestuurslid Robidé van der Aa de laatste eer te bewijzen bij de begrafenisplechtigheid, welke den $14^{\mathrm{n}}$ Februari zal plaats hebben.

Naar aanleiding eener vraag van den Secretaris wordt besloten, van wijlen beide Bestuursleden geen levensberichten vanwege het Instituut's Bestuur te doen opnemen, doch, mocht iemand zich tot het samenstellen daarvan opgewekt gevoelen, hem alsdan de noodige ruimte in de Bijdragen beschikbaar te stellen.

De notulen van het verhandelde in de vorige Vergadering worden gelezen en goedgekeurd, waarna door den Secretaris opgave wordt gedaan van de ontvangen boekgeschenken, welke voor kennisgeving wordt aangenomen.

De Voorzitter deelt mede dat zijn ontvangen:

10. eene missive van den Conservator van de Bibliotheek van Teylers-Stichting te Haarlem, houdende dankbetuiging voor de toezending van de Bijdragen van het Instituut, 5e reeks, dl. II, afl. 1.

20. missives van Mr. R. J. de Wal, Rechterlijk ambtenaar, toegevoegd aan den Voorzitter van de landraden te Magelang en Temanggoeng (Kedoe), en P. J. van der Chijs, Consul der Nederlanden te Djidda, beide houdende kennisgeving van de aanvaarding van het lidmaatschap van het Instituut.

30. eene missive van Mevr. de Wed. Maas Geesteranus, te Delft, waarbij verzocht wordt, wegens het overlijien van haren echtgenoot P. Maas Geesteranus, zijn naam van de ledenlijst af te voeren.

40. eene missive van den heer W. Schagen van Leeuwen, te Delft, houdende verzoek hem van de ledenlijst af te voeren.

50. eene missive van het Bestuur van het Indisch Genootschap, dd. 11 Februari jl., waarbij, in antwoord op een schrijven dezerzijds van 15 Januari te voren, wordt medegedeeld dat de hh. H. D. Canne 5e Volgr. II. 
en J. Boudewijnse, respectivelijk Ondervoorzitter en Secretaris, deel zullen uitmaken van de Commissie, wier mandaat het is te overwegen, of en in hoever eene vereeniging van de bibliotheken van het Indisch Genootschap en het Instituut wenschelijk kan worden geacht.

Al deze missives, sub $10-5^{0}$, worden voor kennisgeving aangenomen.

60. twee missives van Commissarissen in Indië van 22 December 1886, No. B/132 en 7 Januari 1887 , No. B/134, benevens eene briefkaart van 12 Januari 1887.

a. Commissarissen deelen daarin mede, dat aan de leden B. W. Bosman, te Probolinggo, en R. Brons Middel, te Depok, de edita over 1886 nog niet schijnen te zijn geworden, waarom toezending daarvan aan hun adres wordt verzocht, terwijl het lid Neumann, te Padang, bericht heeft gezonden, van de edita van $1886 \mathrm{nog}$ niet anders ontvangen te hebben dan de $4_{e}$ afl. van het le deel der 5e volgreeks der Bijdragen, met verzoek alsnog het ontbrekende te mogen erlangen.

b. Namens en voor het lid L. F. Tuijl Schuitemaker, te Probolinggo, wordt verzocht, op de voorwaarden daarvoor voor leden vastgesteld, een exemplaar te mogen ontvangen van het eerste, derde en vierde deel van de derde volgreeks der Bijdragen, als zijnde daarvan in het boekenfonds geene exemplaren meer voorhanden, terwijl t. z. t. eene opgaaf wordt te gezien van het bedrag, dat genoemd medelid voor de gevraagde boekwerken en de expeditiekosten zal hebben te betalen. Een verzoek van genoemden Heer om uit de werken van het Instituut te putten en over te nemen in een door hem opgericht en weldra te publiceeren Maleisch schooltijdschrift "Soeloeh pengadjar" van datgene, waarvan de kennis voor den inlandschen onderwijzer nuttig en noodig kan worden geacht, hebben Comissarissen gemeend eigener autoriteit te kunnen inwilligen op voorwaarde, dat de bron zal worden vermeld en dat voor de boekerij van het Instituut een exemplaar van het tijdschrift worde afgestaan.

c. Commissarissen berichten verder, dat, met ingang van 1 Januari 1887, als nieuw lid is toegetreden de heer A. de Nooy, leeraar te Samarang; dat met ingang van dienzelfden datum van de ledenlijst moeten worden afgevoerd de heeren van Delden, te Bojolali, mr. W. J. Huber Noordt, te Batavia en C. F. E. Praetorius, te Padang Sidempoean, en dat het lid J. Kreemer medio April naar Nederland. 
vertrekt en de edita wenscht te ontvangen te Rotterdam, adres Gebroeders 'Zwartendijk, terwijl mededeeling wordt verzocht, of door het lid A. Pruys van der Hoeven de contributie over 1886 al dan niet in Nederland is voldaan.

d. Wijders wordt overgemaakt een prima-wissel, groot $f 407 \mathrm{~N}$. C. op de heeren A. van Hoboken \& Co. te Rotterdam, betaalbaar zes maanden na dato, welk bedrag sedert het schrijven van 11 October $1886 \mathrm{No} \mathrm{B} / 131$ aan contributiën is ontvangen.

$e$. Eindelijk wordt de verzending gemeld, in een door het Bataviaasch Genootschap geëxpedieerde kist, van een aantal boekwerkeu, waarvan eene lijst wordt aangeboden.

Overeenkomstig het voorstel van den Voorzitter wordt de Secretaris gemachtigd, onder erkenning van en dankbetuiging voor den ontvangst van de missives van Commissarissen, van de verschillende daarin door hen gedane mededeelingen aanteekening te houden en hun op hunne verzoeken en vragen het noodige antwoord te doen toekomen.

Ter tafel wordt gebracht een schrijven van de firma E. J. Brill, te Leiden, van 20 Januari jl., handelende over de Nederlandsche bewerking en uitgave van het Spaansche werk van Montero y Vidal over de Philippijnen, waaruit blijkt, dat, nu daarvoor vanwege het Departement van Koloniën geene subsidie kan worden verleend, de firma er bezwaar in zag het boek geheel voor eigen rekening en risico uit te geven.

Naar aanleiding van dit schrijven vraagt de Secretaris, of wellicht het Bestuur den een of anderen weg zou kunnen aanwijzen, om de bedoelde uitgave alsnog mogelijk te maken; hoewel hij er zeer veel prijs op zou stellen, dat het Spaansche boek in Nederlandsch gewaad verscheen, heeft hij echter zijnerzijds, met het oog op de geldmiddelen vau het Instituut, geene vrijheid het voorstel te doen thans over te gaan tot het subsidieëren dier onderneming vanwege onze Instelling; doch, waar het uit de gevoerde onderhandelingen gebleken is, dat zij zonder subsidie niet zou kunnen worden tot stand gebracht, wordt in overweging gegeven, vanwege het Instituut althans, geen verdere moeite daarvoor te doen.

$\mathrm{Na}$ eenige gedachtenwisseling wordt overeenkomstig het voorstel van den Secretaris besloten.

In antwoord op het schrijven van het Instithut van 15 Januari /w 
jl. no. 88 is ingekomen een schrijven van den Minister van Koloniën dd. 28 Januari jl. Lett. $\mathrm{A}^{\mathrm{I}}$, no. $\mathbf{1 7}$, houdende mededeeling, dat de Minister geen aanleiding kan vinden om aan het voorstel tot subsidieëring eener door het het Instituut te bezorgen nieuwe editie van het 1e decl der "Boegineesche Chrestomathie" gevolg te geven. De eenige reden, waarom door de Regeering nog niet werd besloten tot een herdruk van dat werk, is hierin gelegen, dat in Indië aan eene nieuwe oplaag nog geene behoefte gevoeld wordt. Het voornemen bestaat om, zoodra die behoefte wèl zal worden gevoeld, voor rekening van den Lande tot een herdruk over te gaan. De Minister zou uit den aard der zaak niets liever verlangen dan bij dien herdruk gebruik te maken van de door Dr. Matthes welwillend aangeboden diensten.

Dit schrijven wordt voor kennisgeving angenomen, terwijl besloten wordt om, na de door den Minister van Koloniën gedane toezegging, af te zien vanwege het Instituut eene nieuwe uitgave van het bedoelde werk van Dr. Matthes te doen bezorgen.

De Secretaris deelt mede:

10. dat hij van den heer Harrebomée heeft terug ontvangen de door dezen bewerkte Nederlandsch-Oeloesche woordenlijst, welke ingevolge de aanwijzingen van de Commissie van Rapporteurs (de heeren Wilken en Niemann) door den Schrijver is herzien, verbeterd en aangevuld. Wordt besloten haar opnieuw in handen te stellen van den heer Niemann.

20. dat nu wijlen het Bestuurslid Robidé van der Aa eenige dagen vóór zijn overlijden hem had ter hand gesteld de resteerende kopij van het door het Instituut alsnog uittegeven tweede gedeelte van Bock's reisverhaal van Koetei naar Banjermasin, met de noodige aauwijzingen, bij den eventueelen druk daarvan in acht te nemen. Aan het werk ontbreekt thans echter nog alleen de door den heer Robidé van der Aa beloofde historische inleiding over Koetei en de betrekkingen van dit leenrijk tot de Regeering van NederlandschIndië. De Secretaris vraagt en erlangt machtiging om hieromtrent in overleg te treden met het medelid S. W. Tromp, laatstelijk assistentresident van Koetei, thans met verlof alhier.

Door de heeren Wilken en Snouck Hurgronje wordt rapport uitgebracht omtrent de in hunne handen gestelde bijdrage van het mede- 
lid Tromp over "de Salasila van Koetei met aanteekeningen". Terwijl de plaatsing van het stuk, voor zoover het uit het toegezonden eerste gedeelte kan worden beoordeeld, na aanvulling en verbetering in den geest van enkele opmerkingen, die zij zich omtrent den reeds geleverden arbeid veroorloven, hun wenschelijk voorkomt, stellen de Rapporteurs voor, het ingeleverd gedeelte voorloopig met mededeeling van de gemaakte opmerkingen aan den heer Tromp terug te zenden, onder aanbeveling voor de toezending van het geheel, wanneer dit afgewerkt zal zijn, opdat dit laatste dan in handen eener Commissie gesteld worde, die een afdoend en volledig rapport zal kunnen uitbrengen.

Eenparig vereenigt de Vergadering zich met dit advies.

Mede namens zijn medelid van Deventer wordt door den heer Kielstra het volgend verslag uitgebracht over het door den heer B. W. Wttewaall van Wickerburgh aangeboden handschrift bevattende eene "Beschrijving van Sumatra's Westkust":

"Ofschoon het handschrift in den regel niet verder gaat dan tot omstreeks 1715, en daarentegen, op eene plaats, (later) tot 1754 is aangevuld, zoo is uit verschillende plaatsen met zekerheid af te leiden dat het omstreeks 1730 moet zijn samengesteld, en wèl, uit de gegevens, welke de archieven te Padang opleverden.

"De naam of de werkkring des schrijvers wordt niet vermeld; doch, naar het ons voorkomt, draagt zijn werk alle kenmerken van nauwkeurigheid en vertrouwbaarheid. Radermacher heeft dan ook, in zijne Beschrijving van het eiland Sumatra (Verhandelingen van het Bat. Gen. v. K. en W., IIIe deel), voor het IVe en Ve Hoofdstuk, over de Westkust handelende, onzen schrijver blijkbaar op den voet gevolgd.

"Radermacher bepaalde zich echter tot een bloot geographisch overzicht, en liet de talrijke bijzonderheden van geschiedkundigen en staatkundigen aard, in het manuscript voorkomende, nagenoeg geheel achterwege.

"Doch het zijn juist die bijzonderheden, welke het manuscript belangrijk maken. Wij vinden hier alles bijeen, wat men omstreeks 1730 van Sumatra's Westkust wist, zoo aangaande de staatkundige toestanden in de verschillende landschappen, als omtrent onze verhoudingen tegenover deze.

"Wij meenen daarom de uitgaaf van het handschrift vanwege het Instituut te moeten aanbevelen, - tenzij zulks, wat het geschied- 
kundig deel betreft, onnoodig mocht blijken door het vervolg der historische studiën des heeren Tiele. Dan zou evenwel toch het gedeelte, over den inwendigen toestand der landschappen langs de Westkust handelende, nog voor openbaarmaking in aanmerking komen.

"In den brief des heeren Wttewaall wordt nog gesproken van de "radicale beschrijving van Sumatra's Westkust", door van Basel in 1761 samengesteld. Van die beschrijving is het historisch gedeelte opgenomen in het Tijdschrift van N.-I., IXe jaargang, en een ander gedeelte (economische en staatkundige beschouwingen) in het Tijdschrift voor Staathuishoudkunde en Statistiek, XIIIe deel, $7^{\mathrm{e}}$ stuk; doch het is niet geheel duidelijk, of ook het geographisch gedeelte in zijn geheel gepubliceerd is. Het zou o. i. wel wenschelijk wezen, dat zulks nog werd nagegaan, en ook dat het boven besproken manuscript nog met de berichten van van Basel vergeleken werd vóór de uitgaaf. Wellicht zou de heer Wttewaall genegen zijn, het handschrift van van Basel, tijdelijk of voor goed, aan de Bibliotheek van het Instituut af te staan. Dit zou ook geheel stroken met het doel van het Instituut (art. $2^{a}$ van het Reglement).

"Volgens het opstel van den heer Wttewaall in het zooeven genoemd Tijdschrift voor Staathuishoudkunde en Statistiek was ZEd. voorts in het bezit van :

een handschrift, bevattende een uittreksel uit de boeken en papieren van de Haagsche Bezoigne (omstreeks 1748);

brieven van Hendrik van Staveren, die van 1763 tot 1771 commandeur te Padang was;

eene secreete Memorie van den Gouverneur-Generaal Mossel, van 1 Mei 1753;

correspondentiën van diens opvolgers, van der Parra en de Klerck, enz.

"Ook deze bescheiden schijnen voor de kennis der toestanden in Indië in de voorgaande eenw van veel belang te zijn. Vermoedelijk zou de heer Wttewaall de wetenschap een dienst bewijzen, indien ZEd. ook deze stukken aan het Instituut toezond."

Eenparig vereenigt de Vergadering zich met deze beschouwingen van de heeren Kielstra en van Deventer en wordt de Secretaris gemachtigd de "Beschrijving van Sumatra's Westkust" in de Bijdragen op te nemen, behoudens de bekortingen en aanvullingen, waarop in het rapport der Commissie wordt gedoeld en die behooren te worden aangebracht na raadpleging van de nader te ontvangen stukken, tot het verkrijgen waarvan de Secretaris de noodige stappen zal doen. 
Onder herinnering aan de algemeene illuminatie, die er ter gelegenheid van 's Konings $70^{\text {en }}$ verjaardag zal plaats hebben, stelt de Secretaris voor, den Penningmeester te machtigen het noodige te doen verrichten om het gebouw van het Instituut te illumineeren.

Dienovereenkomstig wordt zonder beraadslaging besloten.

Door de Commissie, bestaande uit de heeren van Deventer en Kielstra, belast met het nazien der rekening en verantwoording van den Penningmeester over het afgeloopen dienstjaar 1886, wordt, bij monde van eerstgenoemde, daarover verslag uitgebracht. De Com . missie heeft al de noodige stukken nagezien, ze met de justificatoire bescheiden vergeleken en alles in volkomen orde bevonden, weswege zij geen bezwaar maakt het voorstel te doen de rekening en verantwoording vanwege het Bestuur goed te keuren onder dankbetuiging aan den Penningmeester voor zijn financieel beheer.

Dienovereenkomstig wordt besloten, terwijl tevens wordt goedgekeurd, om, ingevolge de bepalingen van het Huishoudelijk Reglement, de rekening alsnog in handen te stellen van eene Commissie van twee gewone leden, ten einde daarover aan de Algemeene jaarlijksche Vergadering verslag uit te brengen. Tot leden dier Commissie worden benoemd de heeren Canne en Humme, aan wie door den Secretaris van hunne benoeming zal worden kennis gegeven.

De Secretaris brengt ter tafel zijn concept-verslag van den staat en de voornaamste lotgevallen en werkzaamheden van het Instituut over het afgeloopen jaar, waarvan door hem mededeeling zal moeten worden gedaan in de a.s. Algemeene Vergadering.

Onder dankbetuiging vereenigt de Vergadering zich met den geleverden arbeid.

In verband met reeds vroeger gehouden besprekingen stelt de Voorzitter voor, onder de agenda voor de Algemeene Vergadering te doen opnemen :

10. een voorstel tot het verleenen van eene doorloopende machtiging aan het Bestuur tot het opnemen van gelden tot een bedrag van hoogstens vijf duizend gulden;

20. een voorstel tot toepassing van de 2 e alinea van Art. 13, met betrekking tot het vanwege het Instituut uit te geven werk van Dr. C. Snouck Hurgronje; en

30. een voorstel tot wijziging van de Artt. 8 en 9 van het Regle- 
ment, en wel in dien zin, dat voortaan de Bestuursleden, die met functiën van Penningmeester en Secretaris belast zijn, dadelijk herkiesbaar zijn, terwijl het Bestuur bevoegd zal zijn niet enkel, gelijk tot dusver den Secretaris, maar ook den Penningmeester, buiten het Bestuur uit de gewone leden te benoemen.

$\mathrm{Na}$ eenige gedachtenwisseling vereenigt de Vergadering zich eenparig met dit drieledig voorstel.

Onder herinnering dat door de periodieke aftreding van drie en het overlijden van twee andere Bestuursleden ditmaal in drie gewone en twee buitengewone vacatures in het Bestuur voorzien moet worden, verzoekt de Voorzitter de Vergadering tot het opmaken van de bij het Reglement daarvoor gevorderde drietallen. Uit de gehouden stemming blijkt, dat aan de Algemeene Vergadering zullen worden aangeboden de volgende drietallen, en wel voor de vacature-van Deventer, de heeren:

H. J. Bool, te Leiden,

H. D. Canne, te 's Gravenhage,

Dr. J. H. F. Sollewijn Gelpke, te 's Gravenhage; vacature-Wilken, de heeren :

Prof. Dr. H. Kern,

Prof. Mr. P. A. van der Lith,

Prof. Dr. J. Pijnappel Gzn., allen te Leiden; vacature-Matthes, de heeren:

Prof. Dr. K. Martin, te Leiden,

Dr. F. A. C. Dumontier, te 's Gravenhage,

Dr. F. A. Jentink, te Leiden; vacature-Juynboll, de heeren:

H. C. Humme, te 's Gravenhage,

J. A. van den Broek, te Delft,

L. K. Harmsen, te Leiden;

vacature-Robidé van der $\mathrm{Aa}$, de heeren :

Dr. T. C. L. Wijnmalen, te 's Gravenhage,

Prof. Dr. C. M. Kan, te Amsterdam,

J. Kuyper Hzn., te 's Gravenhage.

De Vergadering houdt zich vervolgens bezig met de keuze van gewone leden hier te lande en in Oost- en West-Indië en in het buitenland. Eenparig worden aangenomen 
tot gewone leden in Nederland de heeren:

Jhr. Mr. A. P. G. van Karnebeek, Minister van Buitenlandsche Zaken, te 's Gravenhage;

F. C. Tromp, Minister van Marine, te 's Gravenhage;

Mr. W. J. van Welderen Baron Rengers, Lid van de Tweede Kamer der Staten-Generaal, te Leeuwarden;

Mr. D. Visser van Hazerswoude, Lid van de Tweede Kamer der Staten-Generaal, te Amsterdam;

Mr. A. T. K. Hartogh, lid van de Tweede Kamer der StatenGeneraal, te Amsterdam;

Mr. P. J. G. van Diggelen; Lid van de Tweede Kamer der Staten-Generaal, te Zwolle;

Baron W. G. Brantzen van de Zijp, Oud-lid van de Tweede Kamer der Staten-Generaal, te 's Gravenhage;

H. G. Boumeester, Oud-Luitenant-Generaal O.-I. leger, te 's Gravenhage;

G. E. K. L. van Zuylen, Gep. Kolonel van het N.-I. leger, te 's Gravenhage;

W. A. Coblijn, Gep. Kolonel van het N.-I. leger, te Nijmegen;

J. J. H. Gijsberti Hodenpijl, Luitenant-Kolonel der Genie, te Haarlem;

G. W. Beeger, Kapitein van den Generalen Staf, Instructeur aan de $\Pi^{\mathrm{e}}$ afd. der Krijgsschool, te 's Gravenhage;

W. A. Arriëns, Kapitein-Luitenant ter zee, te Rotterdam;

E. B. Bonn, Gep. Kap.-Luit. ter zee, te 's Gravenhage;

W. Cool, Kapitein-Ingenieur, te Breda;

P. H. van Schermbeek, Kapitein-Ingenieur bij het Korps Genie, te Utrecht;

Jhr. Mr. C. J. van Beresteyn, Oud-Vice-President bij het HoogGerechtshof in N.-I., te Rijswijk;

Mr. A. C. Wesenhagen, Oud-Surinaamsch ambtenaar, thans Rechter in de Arr. rechtbank, te Rotterdam;

Jhr. Mr. C. J. den Tex, Lid van den Gemeenteraad, te Amsterdam;

G. Baron Rosenthal, Bankier, Lid van het Bestuur van het Aardr. Genootschap, te Amsterdam;

A. Werumeus Buning, Directeur van het Ethnographisch Museum, te Rotterdam;

Dr. A. C. Oudemans, Directeur van het Kon. Zoöl. Botanisch Genootschap, te 's Gravenhage; 
Dr. H. F. C. ten Kate Jr, te 's Gravenhage;

D. F. van der Pant, Leeraar aan de Instelling van onderwijs in de Ind. taal-, land- en volkenkunde, te Leiden;

P. R. Bos, Leeraar in de Aardrijkskunde aan de Hoogere Burgerschool, te Groningen;

I. J. Dermout, Oud-predikant, te Scheveningen;

C. J. W. Ramann, Directeur van de Stoomvaart-Maatschappij "Nederland", te Amsterdam;

J. A. van Prehn, Lid van de firma van Prehn \& Co., Kassiers te 's Gravenhage;

G. Brunner, Oud-redacteur van de "Java-Bode", thans redacteur van "de Echo", te Amsterdam;

W. P. van Stockum Jr., Boekhandelaar-Uitgever, te 's Gravenhage;

J. H. de Bussy, Uitgever van de "Ind. Mercuur" en de "Revue Coloniale Int.", te Amsterdam;

W. D. J. Brouwer, particulier, te Zwolle.

tot leden in N. Oost- en West-Indië de heeren:

Mr. P. J. Smeele, Procureur-Generaal te Curaçao, m. v., thans Lid van de Tweede Kamer der Staten-Generaal, te 's Gravenhage;

Mr. W. de Gelder, Vice-president van het Hoog Gerechtshof, te Batavia;

Mr. J. H. Abendanon, Lid van den Raad van Justitie, te Batavia;

J. W. Binkes, Schout bij nacht, Kommandant van Z. M's. Zeemacht in O.-I., Chef van het Departement van Marine, te Batavia;

H. K. F. van Teyn, Civiel en militair Gouverneur van Atjeh;

D. Groeneveld, Directeur van de Javasehe Bank, te Batavia;

A. C. Claessens, Aartsbisschop, Apostolisch vicaris en pastoor te Batavia;

Dr. W. Burck, Adj.-Directeur van 's Lands plantentuin, te Buitenzorg;

W. A. Schneider, Kapitein van den Generalen Staf, Adjudant van den Commandant van het leger, te Batavia;

C. Deykerhoff, Luitenant-Kolonel van den Generalen Staf, te Batavia;

J. J. Staal, Majoor der Genie, te Batavia;

F. J. Haver Droese, Kapitein van den Generalen Staf, te Padang;

W. C. Nieuwenhuijzen, Kapitein der Infanterie, te Atjeh;

W. J. N. Bosboom, Kapitein der Infanterie, te Batavia;

H. W. Scheuer, Kapitein der Genie, te Batavia; 
J. C. Th. Kroesen, resident van Besoeki, thans met verlof, te 's Gravenhage;

Mr. W. A. P. T. L. Winckel, Rechterlijk ambtenaar in N.-I., met verlof, te 's Gravenhage;

J. P. C. Hartevelt, Adj.-Inspecteur van Financiën, met verlof, te 's Gravenhage;

Dr. B. Hagen, Geneesheer te Deli;

David Lopez Penha Jr., Consul-Generaal der Ned. bij de Vereenigde Staten van Columbia, te Baranquilla.

Tot buitenlandsch lid:

Prof. F. Blumentritt, te Leitmeritz, Bohemen.

Van deze keuze zal aan de Algemeene Vergadering mededeeling worden gedaan.

Door het Bestuurslid Dr. Snouck Hurgronje wordt voor de Bibliotheek van het Instituut aangeboden eene verzameling photografieën, gedurende zijne reis naar en zijn verblijf in Arabië bijeengebracht, onder voorwaarde echter, dat zij zonder zijn verlof niet mogen worden gereproduceerd.

Onder toejuiching der Vergadering, zegt de Voorzitter den heer Snouck Hurgronje dank voor zijn welkom en belangrijk geschenk.

Niets meer hierna aan de orde zijnde, wordt de Vergadering door den Voorzitter gesloten. 


\section{ALGEMEENE VERGADERING,}

GEHOUDEN 26 FEBRUARI 1887.

Tegenwoordig de heeren van Rappard (Voorzitter), van Deventer (Onder-voorzitter), J. H. de Groot (Penningmeester), Wijnmalen (Secretaris), Kielstra, Albrecht, Lion, Jentink, van Rhede van der Kloot, Matthes, Weitzel, Schlegel, Canne, Wilken, van Limburg Stirum, van Alphen, Neys, Boele van Hensbroek, Harmsen, Quarles van Ufford, Kern, Niemann, Rochussen, Schmidt, Snouck Hurgronje, Humme, Huyser, Serrurier en het correspondeerend lid Schmeltz.

$\mathrm{Na}$ opening der Vergadering heet de Voorzitter de leden welkom, ditmaal echter met een gevoel van diepen weemoed, waar het verlies van twee Bestuursleden te betreuren valt. Werd reeds aan de geopende groeve een woord gesproken van erkentelijke waardeering van de vele verdiensten van Prof. Dr. Juynboll en Robidé van der Aa, ook de Voorzitter mag de jaarlijksche Vergadering niet doen aanvangen zonder hulde te brengen aan den grondigen kenner van het Moslemsch recht en den degelijken beoefenaar der geographische wetenschap en vertrouwt dat hunne nagedachtenis door de leden in eere zal worden gehouden.

De notulen van het verhandelde in de vorige Algemeene Vergadering, bereids door het Bestuur voorloopig vastgesteld en in de Bijdragen opgenomen, worden gelezen en alsnu definitief goedgekeurd.

Door den Secretaris wordt Verslag uitgebracht van den staat en de voornaamste lotgevallen en werkzaamheden van het Instituut gedurende het afgeloopen jaar 1886 .

Onder toejuiching der Vergadering, zegt de Voorzitter hem dank voor den geleverden arbeid, en wordt zonder beraadslaging of hoofdelijke stemming besloten het Verslag te doen opnemen in de eerstvolgende aflevering der Bijjdragen. (Zie Bijdragen, dl. II, 5e serie, blz. III). 
Aan de orde is vervolgens de rekening en verantwoording van den Penningmeester over 1886, waarbij medegedeeld wordt, dat zij bereids vanwege het Bestuur door de heeren Kielstra en van Deventer nagezien en overeenkomstig hun advies goedgekeurd, ingevolge de bepalingen van het Huishoudelijk Reglement, in handen gesteld is van eene Commissie van twee gewone leden, zijnde de heeren Canne en Humme, die, alsnu het woord verkrijgende, bij monde van laatstgenoemde omtrent hare bevinding het volgend verslag uitbrengt:

"Daartoe door het Bestuur van het Instituut uitgenoodigd, heeft de Commissie op 20 dezer de door den Penningmeester gehouden geldelijke administratie over het afgeloopen dienstjaar onderzocht, en daartoe zoowel het Kasboek als de andere verantwoordingsstukken, Balans, Budget, enz., nauwkeurig nagezien en met elkander vergeleken.

"Onze bevinding was:

a. dat de geraamde ontvangsten bedroegen . . . f 6,745.maar de werkelijke ontvangsten . . . . . . . $-7,798.22$ zoodat meer is ontvangen dan geraamd . . . . - $-1,053.22$

"Onder deze som van $f 1,053.22$ is begrepen $f 249.08$ wegens meerdere contributiën van leden. Deze toename van 't getal betalende nieuwe leden constateeren wij als een verblijdend verschijnsel.

b. De geraamde uitgaven waren . . . . . f 7,123.61 $\frac{1}{2}$ terwijl de werkelijke nitgaven hebben bedragen . $\quad$ - $7,568.39$

Alzoo is er meer vitgegeven . . . . . . . f $\overline{444.77 \frac{1}{2}}$

"Deze meerdere uitgaaf heeft de Penningmeester kunnen bestrijden uit het batig saldo van 't vorige jaar, dat een som van $f 830.20$ bedroeg.

c. Het batig saldo van het nu afgeloopen dienstjaar bedroeg f 229.83.

d. Tevens constateeren wij met genoegen, dat onder de uitgaven van 't afgeloopen dienstjaar voorkomt een bedrag van $f] 000$, benevens $f 45.85$ rente, wegens het opnemen van geld bij een onzer leden op 't oogenblik dat 't Instituut geen geld genoeg in kas had, om hare taak te volbrengen, zoodat derhalve ook die schuld is afgedaan.

e. De nieuwe Begrooting vonden wij gelijk aan de vorige. Alleen is daarbij een vaste post van $f 500$ opgebracht ten behoeve van den Secretaris, voor wien tot heden toe slechts $f 100$ was toegestaan. In aanmerking nemende de moeielijke en tijdroovende werkzaamheden van den Secretaris, die hij zoo nauwgezet en tevens zoo 
hoogst verdienstelijk vervult, kunnen wij niet anders dan deze meerdere toelage goedkeuren, en zelfs toejuichen, als een bewijs hoezeer wij zijne diensten op prijs stellen.

$f$. Het saldo was in de kas aanwezig.

g. Wij stellen derhalve de Vergadering voor het beheer van den Penningmeester over het dienstjaar 1886 goed te keuren en tevens den Penningmeester onzen welgemeenden dank te betuigen voor de nette en nauwgezette wijze, waarop hij zich van zijne taak heeft gekweten."

Aan dit Verslag worden door den Penningmeester nog de volgende mededeelingen toegevoegd :

"10. de Kas.

a. De ontvangsten gedurende het jaar 1886 hebben bedragen .

Het saldo in kas op 1 Januari 1886 bedroeg. . . - 830.20

te samen

$f 7798.22$

Hieronder behooren remises uit Indië van hh. Commissarissen voor inkasseering der contributiën van leden en toelage uit de Ind. kas, te samen ten bedrage van . . . . . . . . . . . . . $f 1754.08$ en van leden in Nederland . . . . . - 3400.Telt. $\overline{f 5154.08} f 5154.08$

De raming van te ontvangen contributiën over 1886 was . . . . . . . . . $f 4905$. zoodat meer aan contrib. werd ontvangen $f 249.08$ welke verhooging mag worden toegeschreven door vermeerdering van het ledental en de geregelde inningen der contributiën.

Voorts werden ontvangen:

voor het gebruik der lokalen

voor opbrengst der verkochte boekwerken door den heer Nijhoff over 1885 . . . . . . . . . . . - 1413.94

Hierbij gevoegd het saldo in kas op 31 December 1886 - 830.20 te samen uitmakende het bedrag der ontvangst . . $\overline{f 7798.22}$ zooals hierboven is vermeld.

b. De uitgaven over 1886 beliepen als volgt:

Voor de uitgaven: brandassurantie, grondbelasting, onderhoud van het gebouw, verwarming der lokalen, gas, duinwater, salaris van den Concierge, onkosten van den 
Secretaris en Penningmeester (art. 1-14 Begrooting) . $f$ 1231.22 Voor gewone drukwerken (art. 15) . . . -2356.15 " buitengewone " (art. 16) . . - 321.38 " afzonderlijke " $\quad$ (art. 17) . . - 793.88

" honorarium aan Schrijvers (art. 20) . . - 537.50

" uitbreiding van de Boekerij (art. 21) . . . - 561.45

" kosten verzending der Bijdragen (art. 23) . . . - 520.96

" salaris van den Schrijver . (art. 24) . . . - 200.-

" terugbetaling verschot en rente (art. 25) . . . - 1045.85

Total bedrag der uitgaven . $\overline{f 7568.39}$

Hierbij geteld het saldo der kas op 31 December 1886 ad - 229.83 dan verkrijgt men het totaal bedrag der kas . . . $\overline{f 7798.22}$ elijk aan de som der ontvangst hierboven vermeld.

20. de Balans.

De Activa voor 1886 bedroeg . . . . . . . $f 41.439 .83$ volgens onderstaande omschrijving: waarde van het Pand. . . $f$ 23,000.-

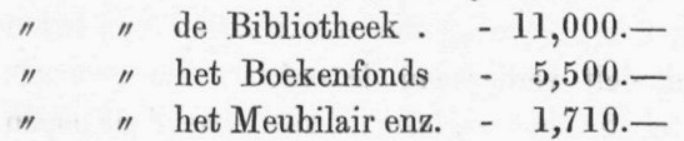

het saldo in kas op 31 December 1886 - 229.83 f 41,439.83

De gewone afschrijvingen hebben wederom plaats gehad. In het geheel zijn afgeschreven gedurende 1883 -' 86 op 't gebouw $f 3,500$. -
" 1882 -'86 op 't meubilair - 450.-
te samen . . . $f 3,950 .-$

Het Instituut is in het afgeloopen jaar belangrijk vooruitgegaan, in aanmerking genomen dat het voorschot ad $f 1000$ is aangezuiverd en alle achterstallige rekeningen over 1885 zijn voldaan."

De Voorzitter stelt voor overeenkomstig het advies der Commissie de rekening en verantwoording van den Penningmeester over het dienstjaar 1886 goed te keuren, onder dankbetuiging zoowel voor zijn financieel beheer als voor de door hem verstrekte inlichtingen.

Onder toejuiching der Vergadering, wordt zonder beraadslaging of hoofdelijke stemming dienovereenkomstig besloten.

De Vergadering gaat hierna over tot de verkiezing van Bestuursleden in de plaats van de aftredende leden S. van Deventer, Dr. B. F. Matthes en Prof. Dr. G. A. Wilken en van wijlen de heeren Prof. Dr. A W. T. Juynboll en P. J. B. C. Robidé van der Aa, 
waarvoor de bij het Reglement gevorderde drietallen aan de Vergadering worden aangeboden. (Zie de Notulen der Bestuursvergadering van 12 Februari jl.)

Tot stemopnemers worden benoemd de heeren Boele van Hensbroek en Neys, die, na korte pauze, mededeelen, dat de uitslag der stemming is, dat met groote meerderheid van stemmen tot leden van het Bestuur zijn verkozen de heeren H. J. Bool, Prof. Dr. H. Kern, Prof. Dr. K. Martin, te Leiden, H. C. Humme en Dr. Th. C. I. Wijnmalen, te 's Gravenhage.

Onder dankbetuiging aan de stemopnemers voor de vervulling hunner taak, wenscht de Voorzitter het Instituut geluk met de gedane keuze.

Ter vergadering tegenwoordig, verklaren, in antwoord op eene door den Voorzitter tot hen gerichte vraag, de heeren Kern, Humme en Wijnmalen zich bereid de benoeming te aanvaarden, terwijl aan de heeren Bool en Martin van de uitgebrachte keuze zal worden kennis gegeven.

\section{De Voorzitter stelt verder aan de orde}

I. het voorstel tot het verleenen van eene doorloopende machtiging aan het Bestuur tot het opnemen van gelden tot een bedrag van hoogstens vijf duizend gulden.

Namens het Bestuur licht de heer Kielstra dit voorstel toe, waarvan de strekking geene andere is, dan om aan het Bestuur gelegenheid te geven in oogenblikkelijke geldelijke behoefte te voorzien; was er vroeger eenig kapitaal benevens eene hypotheek op het gebouw, deze laatste heeft men geheel afgelost, waarvoor de realiseering van het kapitaal noodig was; doch daardoor was tevens de kas geheel uitgeput, zoodat men de bestrijding zoowel der gewone als buitengewone uitgaven vaak eenigen tijd moest uitstellen of wel door het nemen van eenig voorschot in de gebleken behoeften voorzien.

Op eene vraag van den heer Jhr. E. T. M. van Alphen, waarom men niet liever weder eene hypotheek op het gebouw wil vestigen, dan eene leening sluiten, antwoordt de heer Kielstra, dat eerstgenoemd middel niet enkel in de uitvoering met verhooging van kosten gepaard gaat, alzoo financieel nadeelig is, doch dat het daarom niet boven het ingediende voorstel aan te bevelen is, daar de bedoeling van dit laatste is om aan het Bestuur machtiging te geven tot het opnemen van gelden, zoodra het blijken mocht dat daaraan behoefte bestaat; de bedoeling is om niet aanstonds tot eene leening van hoogstens vijf 
duizend gulden over te gaan, maar om aan het Bestuur de bevoegdheid te verzekeren, alleen zóó noodig, eenig kasgeld te kunnen verkrijgen.

Niemand verder hierover het woord verlangende, wordt het voorstel in omvraag gebracht en met algemeene stemmen aangenomen.

II. het voorstel van het Bestuur tot wijziging van de artt. 8 en 9 van het Reglement, en wel 10. om de eerste zinsnede van de 2e alinea van art. 8 te lezen als volgt: "Elk jaar treden, naar rang van benoeming, drie leden af. De Bestuursleden, die met de functiën van Penningmeester en Secretaris belast zijn, zijn dadelijk herkiesbaar; de overigen eerst na verloop van een jaar;" en 20 . in de 20 en 3 e alinea van Art. 9 de woorden te voegen: "en den Penningmeester" en alzoo te lezen: "Het Bestuur is bevoegd den Secretaris en den Penningmeester, buiten het Bestuur, uit de gewone leden te benoemen.

"De buiten het Bestuur benoemde Secretaris en Penningmeester hebben in de Bestuursvergadering slechts eene raadgevende stem."

Deze wetswijziging toelichtende, zegt de Voorzitter dat de ondervinding van vele jaren de wenschelijkheid daarvan heeft doen inzien; evenals dit reeds met het Secretariaat het geval is, moet ook voor den Penningmeester de gelegenheid worden aangeboden zich met de vervulling zijner taak belast te zien, zonder dat zijne aftreding als bestuurslid daarvoor een bezwaar oplevert.

Daar niemand over het voorstel het wordt verlangt, worden de beraadslagingen gesloten; in omvraag gebracht, wordt het met algemeene stemmen aangenomen.

III. het voorstel van het Bestuur tot toepassing van de 2e alinea van Art. 13, met betrekking tot het vanwege het Instituut uit te geven werk van Dr. Snouck Hurgronje.

De Secretaris, dit voorstel toelichtende, refereert zich aan hetgeen door hem daaromtrent reeds in zijn Verslag medegedeeld, waarna, daar niemand verder daarover het woord verlangt, de beraadslagingen worden gesloten en het voorstel zelf, zonder hoofdelijke stemming, met acclamatie, wordt aangenomen.

Aan de Vergadering wordt medegedeeld, dat het Bestuur gebruik makende van de hem verleende bevoegdheid, zoowel hier te lande als in Oost- en West-Indië en in het buitenland aan enkele personen het lidmaatschap heeft aangeboden, wier namen vervolgens door den 5e Volgr. II. 
Secretaris worden voorgelezen. (Zie Notulen van de Bestuursvergadering van 12 Februari jl.). Voor kennisgeving aangenomen.

De heer Dr. L. Serrurier vraagt en erlangt het woord, vooreerst om een afschrift aan te bieden van het verslag, dat door hem in November des vorigen jaars aan de Regeering is overgelegd betreffende den stand der Wajanguitgave, waarvoor de Voorzitter hem dank zegt 1.

In de tweede plaats brengt Spreker in herinnering, dat bij de Indische Begrooting voor 1883 voor het eerst is gevraagd en toegestaan een bedrag van $f 10.000$ ter subsidieering van wetenschappelijke reizen in de Nederlandsche bezittingen in Oost-Indië, met de bedoeling, zooals zulks later door de Regeering is verklaard, om dien post verder jaarlijks op de begrooting te brengen.

Daarna vermeldt Spreker in bijzonderheden, hoe door het Aardrijkskundig Genootschap eerst een plan is opgemaakt voor een onderzoekingstocht in het Noordelijk gedeelte onzer bezittingen ter Oostkust van Borneo, vervolgens - toen dat plan niet werd goedgekeurd - naar de zuidelijke streken ter Ooskust, met het voornemen om met de ontdekkingstochten geleidelijk in noordelijke richting voort te gaan. Spreker heeft in de Koloniale Verslagen niet

1 Het werk bestaat uit veertien platen, waarvan sommige dubbel zijn.

Afgewerkt zijn de platen I tot en met X a, XI, XIII en XIV.

Derhalve zijn nog te maken plaat $\mathrm{X} b$ en $\mathrm{XII} a$ en $b$.

Door het Koninklijk Instituut voor de Taal-, Land- en Volkenkunde van Nederlandsch Indië zijn betaald de navolgende platen: I a , b, IV, V, VII a, b, XI en XIV voor den gezamenlijken prijs van $f 1500$.

In 1881 werd voor de uitgave $f 250$ toegestaan, waarmede de nota van den photograaf tot dat bedrag betaald werd.

In 1882 werd de post voor wajanguitgave door de Tweede Kamer der StatenGeneraal verworpen.

In 1883 werden betaald de platen IX en XIII met . $f 300$

en restant nota van den photograaf met. . . . $\frac{-200}{f 500}$

In 1884 werd betald de nota van den timmerman voor het maken van houten kisten voor de oplage, ad. . . . . . . . . . . . . . . . . $f$ 36. en werden gedeclareerd de platen II a en b tot een gezamenlijk bedrag van -464 . -

In 1885 werden betaald de platen VI $a$ en $b$ en VIII a ter somma van - 500.-

In 1886 zullen worden gedeclareerd de platen $\mathrm{VIII} b$, III en $\mathrm{X}$ a tot een gezamenlijk bedrag van . . . . . . . . . . . . - 500.-

Alzoo is het te verwachten, dat in 1887 de bewerking en de druk der platen zal zijn geëindigd. In dat jaar zal dan tevens de bewerking van den tekst ter hand worden genomen, zoodat na afloop van den druk der platen het drukken van den tekst kan worden aangevangen. 
kunnen ontwaren hoe dit tweede plan door de Regeering is opgenomen. Maar het Koloniaal Verslag over 1884 spreekt van een nieuw plan, nl. om naar Engano te gaan, een plan waarvan het denkbeeld oorspronkelijk was uitgegaan van den Utrechtschen Hoogleeraar Hubrecht en van Spreker zelven, die daarvoor uitvoerige instructiën opstelden. Verder heeft Spreker van het Aardrijkskundig Genootschap niets meer omtrent dit plan vernomen, dat in de opvolgende Koloniale Verslagen ook niet meer ter sprake wordt gebracht.

Een vierde plan wordt inmiddels ontworpen, namentlijk om naar West-Nieuw-Guinea te gaan. Daarvoor werd $f 15,000$ boven het gewone subsidie gevraagd, doch door de Tweede Kamer geweigerd. Spreker maakt van deze gelegenheid gebruik, om te protesteeren tegen de bewering van het Bestuur van het Aardrijkskundig Genootschap, dat voor de Nieuw-Guinea expeditie door hem zou zijn aanbevolen de natuurkundige, op wien voor die expeditie de keus des Genootschaps gevallen was. Spreker is door het Genootschap noch om advies gevraagd, noch heeft hij zoodanig advies uit zichzelven ten beste gegeven.

Thans, zegt Spreker, zijn wij aan het vijfde plan, nl. om naar de Aroe-eilanden een expeditie uit te zenden.

Vier jaren achtereen is er $f 10,000$ toegestaan, alzoo $f 40,000$, waarvan bijna niets is ten goede gekomen aan het wetenschappelijk onderzoek van Ned.-Indië. Bijna niets; want men mag aannemen dat uit die gelden zijn gekweten de 500 dollars, die Dr. Hagen ontvangen heeft om in 1883 een wetenschappelijke reis te doen naar het Zuidoostelijk en Oostelijk deel van het Tobameer. De geringheid der ontvangen subsidie heeft Dr. Hagen niet belet nog eene zoölogische, mineralogische en ethnologische verzameling ter beschikking der Indische Regeering te stellen, terwijl zijn rapport aan het Bataviaasch Genootschap is afgestaan ter publiceering in zijn Tijdschrift. 1

Al de plannen van het Aardrijkskundig Genootschap zijn tot dusver onuitgevoerd gebleven. Spreker wil gaarne aannemen, dat het Aardrijkskundig Genootschap in allerongunstigste omstandigheden verkeerd heeft, maar hij is niet overtuigd, dat alles in het werk gesteld is om die plannen te doen gelukken of althans die jaarlijksche $f 10,000$ niet verloren te doen gaan.

1 Staande de Vergadering werd de mededeeling ontvangen, dat ook dit vijfde plan is opgegeven. 
Had men b. v. de Regeering na de mislukking der beide eerste plannen niet een keuze kunnen aanbieden van 2 of 3 projecten tegelijk? Had men geen gevolmachtigde te Batavia kunnen benoemen om mondeling met de Regeering te onderhandelen? Nog erger. Blijkens het Koloniaal Verslag over 1884 heeft Dr. Hagen zich beschikbaar gesteld voor verdere wetenschappelijke onderzoekingen in de Bataklanden (en natuurlijk ook elders) tegen eene tegemoetkoming van $f 300$ 's maands, waartegen de Regeering in beginsel geen bezwaar had; doch het Aardrijkskundig Genootschap kwam niet op de gedachte, althans niet tot de uitvoering, om zich met dezen hoogst verdienstelijken natuuronderzoeker in betrekking te stellen, maar bleef zich binnen zijne eigene plannen opsluiten. Toen het verhoogd subsidie voor 1886 was afgestemd, werd de Nieuw-Guinea-expeditie eenvoudig opgegeven.

In weerwil van dit alles is in de Tweede Kamer en daarbuiten herhaaldelijk gezegd, dat het Aardrijkskundig Genootschap het aangewezen lichaam is om wetenschappelijke expeditiën te organiseeren en tot staving daarvan werd de Sumatra-expeditie aangehaald. Spreker wil de verdiensten dier expeditie op ethnographisch gebied geenszins verkleinen, maar herinnert alleen dat de expeditie haar programma niet heeft uitgevoerd en dat zij bovendien veel te duur is geweest, hetgeen met cijfers nader wordt aangetoond. Spreker is geen tegenstander van het Aardrijkskundig Genootschap, maar hij is in de eerste plaats een voorstander van expedities. Daarom komt hij op tegen de voorstelling als ware het Aardrijkskundig Genootschap uitsluitend bevoegd of in staat om wetenschappelijke expedities te organiseeren. Naar zijne meening is het Instituut even goed als het Aardrijkskundig Genootschap het aangewezen lichaam. Het Instituut heeft in zijn bestuur even goede krachten als het Aardrijksknndig Genootschap. Het kan daarenboven beschikken over de rijke hulpbronnen die de Universiteit en de Musea te Leiden op zoo korten afstand aanbieden.

Maar er is nog een reden, waarom Spreker zou wenschen dat het Instituut ook eens het initiatief nam tot een expeditie. Het Aardrijkskundig Genootschap heeft, zooals door het Bestuur herhaaldelijk, blijkens de Koloniale Verslagen, verzekerd is, vooral met zijne NieuwGuinea-plaunen een kustonderzoek bedoeld, een nautisch-geographisch onderzoek, waarbij ook tevens door een jeugdig zoöloog lagere dieren zouden worden verzameld. Het komt Spreker voor dat zoodanig kustonderzoek reeds geschiedt vanwege het Departement van Marine en dus dat hier door het Aardrijkskundig Genootschap alleen wordt aangevuld; zoodanige aanvulling nu is als weelde te beschouwen, wanneer op 
zooveel ander gebied het eerste onderzoek nog moet plaats hebben. En wat de lagere dieren betreft. Even belangrijk zijn ze als de hoogere, maar de hoogere zullen zijn uitgestorven, wanneer de lagere dieren nog in hunnen oorspronkelijken staat aanwezig zullen zijn. Het onderzoek van de hoogere dieren en van den mensch is als het meest urgent te beschouwen, welk denkbeeld door Spreker nader wordt ontwikkeld. Varen we daarentegen onder de vlag van het Instituut, zegt Spreker, dan kunnen wij blijkens den naam dezer Instelling gegronde hoop koesteren, dat niet alleen de kennis van het "land", maar ook de "taal-, de volkenkunde" en andere studievakken een punt van zeer ernstige overweging zullen uitmaken bij de keuze van eventueel uit te zenden onderzoekers. Naarmate van de speciale studiën van den reiziger zou dan bij eene expeditie het zwaartepunt nu eens in de eene, dan in de andere rubriek van onderzoekingen moeten gelegd worden.

Daarom doet Spreker, mede uit naam van zijn ambtgenoot, Dr. Jentink, het volgende voorstel: "het Bestuur in overweging te geven zich te wenden tot de Nederlandsch-Indische Regeering met het verzoek om een kleinen wetenschappelijken onderzoekingstocht van een of twee personen naar een nader aan te wijzen deel van Nederl. Indië te mogen organiseeren, hetzij na afloop der thans door het Aardrijkskundig Genootschap voorgenomen expeditie naar de Aroe-eilanden, hetzij wanneer noch in dit, noch in het volgende jaar deze laatste expeditie tot uitvoering mocht komen; en zulks met gebruikmaking gedurende twee of meer achtereenvolgende jaren van het jaarlijks ter beschikking der Indische Regeering komende bedrag van $f 10,000$ voor wetenschappelijke reizen."

$\mathrm{Na}$ een protest van de heeren Quarles van Ufford en Wijnmalen tegen de beschouwingen van Dr. Serrurier betreffende de werkzaamheid van het Aardrijkskundig Genootschap, worden de beraadslagingen omtrent het ingediende voorstel gesloten en verklaart het Bestuur zich bereid het in ernstige overweging te nemen.

De heer Lion, het woord gevraagd en verkregen hebbende, vestigt de aandacht van het Bestuur op de uitgave van de Notulen van de Algemeene en Bestuurevergaderingen in de Bijdragen en vraagt of het niet mogelijk en wenschelijk zou zijn, de Notulen telkens afzonderlijk uit te geven, evenals zulks o. a. geschiedt bij het Bataviaasch Genootschap van Kunsten en Wetenschappen.

De Secretaris antwoordt, dat het geopperde denkbeeld hem zeer toe- 
lacht; hoewel een voorstel tot afzonderlijke uitgave der Notulen dusver geene voldoende ondersteuning mocht verwerven, vertrouwt hij echter dat het Bestuur wel bereid zal zijn opnieuw den gegeven wenk in overweging te nemen.

De Secretaris deelt mede, dat hij, staande de Vergadering, van den notaris C. E. P. Pauwels alhier een extract heeft ontvangen uit het Testament van wijlen ons medebestuurslid P. J. B. C. Robidé van der $\mathrm{Aa}$, bevattende eene beschikking ten behoeve van de $\mathrm{Bi}$ bliotheek van het Instituut; en wel deze, dat nadat de beheerders der Koninklijke Bibliotheek uit diens verzameling boeken, kaarten, atlassen en handschriften ten behoeve dier rijksinstelling al hebben genomen wat daar niet aanwezig is, de boekbewaarder van het Instituut onder dezelfde voorwaarden eveneens doen zal, echter uitsluitend zulke geschriften, die in den ruimsten zin aan de Indologische en Koloniale wetenschappen gewijd zijn.

Niemand hierna meer het woord vragende, gelooft de Voorzitter de tolk der Vergadering te zijn, door den aftredenden bestuurders van Deventer, Matthes en Wilken dank te betuigen voor de vele diensten, die zij gedurende den tijd van hun lidmaatschap van het Bestuur voor het Instituut hebben willen verrichten, terwijl de bevordering van zijn bloei hun zoowel als den overigen leden bij voortduring zij aanbevolen, met welken wensch de Voorzitter tevens de Vergadering sluit. 


\title{
28] sTE BESTUURSVERGADERING
}

\author{
GEHOUDEN 19 MAART 1887.
}

Tegenwoordig de heeren van Rappard, Kern, Bool, Martin, Snouck Hurgronje, Schlegel, Humme, Riedel, Kielstra, J. H. de Groot en Wijnmalen. Afwezig met kennisgeving de heer Niemann.

$\mathrm{Na}$ opening der vergadering deelt de Voorzitter mede, dat van de heeren Bool en Martin bericht is ontvangen van de aanvaarding hunner benoeming tot leden van het Bestuur van het Instituut. Ter vergadering tegenwoordig, heet de Voorzitter hen, evenals ook de nieuw benoemde Bestuursleden, de heeren Kern, Humme en Wijnmalen, welkom, onder aanbeveling van de belangen van het Instituut aan hunne goede zorgen, waarna worden voorgelezen en goedgekeurd de notulen van het verhandelde in de vorige gewone Bestuursvergadering, terwijl evenens voorloopig worden vastgesteld, ter opueming in de Bijdragen, de notulen van het verhandelde in de den 26 Februari jl. gehouden Algemeene jaarlijksche Vergadering.

Ingevolge het voorschrift, in art. 9 van het Reglement vervat, gaat de Vergadering over tot de verkiezing van een Voorzitter, Onder-Voorzitter, Penningmeester en Secretaris.

Uit de gehouden stemming blijkt dat met meerderheid van stemmen tot het vervullen dier betrekkingen benoemd zijn de heeren Kern, van Rappard, J. H. de Groot en Wijnmalen, die allen vervolgens verklaren, dat zij, onder dankzegging voor het in hen gesteld vertrouwen, zich de keuze laten welgevallen.

De heer Kern, hierna den Voorzitterszetel ingenomen hebbende, verzoekt den Secretaris-Bibliothecaris aan de Vergadering de aanwinsten der Bibliotheek te willen mededeelen, die, daaraan voldoende, mededeelt, dat zijn ingekomen:

10. een exemplaar van no. 9 van "De Nederlandsche Spectator" 5e Volgr. II. 
van 26 Februari jl., waarin levensberichten voorkomen van wijlen de bestuursleden P. J. B. C. Robidé van der Aa en Prof. Dr. A. W. T. Juynboll.

20. eene missive van den Minister van Staat, Minister van Binnenlandsche Zaken, van 17 Februari 1887, LA A., afd. K. W., ten geleide van eenige genootschappelijke geschriften, voor het Instituut bestemd en ontvangen van de Fransche Commissie voor internationale ruilingen te Parijs.

30. eene missive van den Minister van Buitenlandsche Zaken, dd. 1 Maart 1887, le afd. no. 1808, waarbij wordt toegezonden een exemplaar van een door tusschenkomst van den Consul der Nederlanden te Saïgon ontvangen en aldaar verschenen werk, getiteld: "Contes Tjames. Texte en caractères Tjames accompagné de la transcription du premier conte en caractères romains et d'un lexique," 't welk door den schrijver, den heer A. Landes, an het Instituut wordt aangeboden.

40. missives van de Koninklijke Akademie van Wetenschappen, te Amsterdam, van 23 November 1886 en 15 Februari '87, ten geleide van de door de Akademie laatstelijk uitgegeven Verslagen en Mededeelingen, afd. Natuurkunde, 3e Rks. dl. III, 1, en afd. Letterkunde, 3e Rks. dl. III, 3, onder dankbetuiging tevens voor de toegezonden Bijdragen van het Instituut, 5e Reeks, dl. I, afl. 3 en 4 en dl. II, afl. 1 .

50. missives van de Directie van het Museum-Guimet te Parijs, ten geleide van de laatstelijk door die Instelling uitgegeven geschriften.

60. eene missive van den heer Vte de Pindella, Minister-Resident van Portugal, te 's Gravenhage, waarbij, onder dankzegging voor het toegezonden exemplaar van het werk des heeren J. A. van der Chijs over "Neêrlands streven tot openstelling van Japan voor den wereldhandel", voor de Bibliotheek van het Instituut wordt aangeboden een exemplaar van zijn geschrift, getiteld: "Les Iles de St. Thomas et du Prince. Notes sur une administration coloniale."

70. eene missive van de Directie van het Observatorium te Batavia, ten geleide van het laatstelijk verschenen dl. VI en suppl. dl. VII der Observations en dl. VII, 1885, der Regenwaarnemingen.

$\mathrm{Al}$ deze missives worden voor kennisgeving aangenomen; plaatsing der ingekomen boekwerken in de Bibliotheek onder dankbetuiging aan de inzenders. 
Nog zijn ingekomen:

10. eene missive van den Secretaris van het "Elizabeth Thompson Science Fund," te Boston, Mass., U. S. A., houdende verzoek mededeeling te doen van de volgende circulaire:

"This fund, which has been established by Mrs. Elizabeth Thompson, of Stamford, Connecticut, "for the advancement and prosecution of scientifi: research in its broadest sense, "now amounts to 25,000 doll. As accumulated income is again available, the trustees desire to receive applications for appropriations in aid of scientific work. This endowment is not for the benefit of any one department of science, but it is the intention of the trustees to give the preference to those investigations which cannot otherwise be provided for, which have for their object the advancement of human knowledge or the benefit of mankind in general, rather than to researches directed to the solution of questions of merely local importance.

"Applications for assistance from this fund should be accompanied by a full statement of the nature of the investigation, of the conditions under wich it is to be prosecuted, and of the manner in wich the appropriation asked for is to be expended. The applications should be forwarded to the Secretary of the Board of Trustees, Dr. C. S. Minot, Harvard Medical School, Boston, Mass, U. S. A.

"The new grants will propably be made in May, 1887.

"The following grants have been made: -

1. 200 doll., to the New England Meteorological Society for the investigation of cyclonic movements in New England.

2. 150 doll., to Samuel Rideal, Esq., of University College, London, England, for investigations on the absorption of heat by odorous gases.

3. 75 doll., to H. M. Howe, Esq., of Boston, Mass., for the investigation of fusible slags of copper and lead smelting.

4. 500 doll., to Prof. J. Rosenthal, of Erlangen, Germany, for investigations on animal heat in health and disease.

5. 50 doll., to Joseph Jastrow, Esq., of the Johns Hopkins University, Baltimore, Md., for investigations on the laws of psycho-physics."

Voor kennisgeving aangenomen.

20. een circulaire van den heer Franz Heger, I, Burgring, K. K. naturhistorisches Hofmuseum, te Weenen, houdende mededeeling van zijn optreden als Secretaris van de Anthropologischen Gesellschaft, 
tevens Redacteur der "Mittheilungen", met verzoek alle voor genoemde Vereeniging bestemde stukken of gedrukten aan zijn adres te willen toezenden.

Wordt besloten hiervan aanteekening te houden.

30. eene missive van den heer B. W. Wttewaall van Wickerburgh, te Utrecht, dd. 16 Maart jl., houdende mededeeling, dat hij, ingevolge het hem gedaan verzoek, gaarne aan het Instituut afstaat het vroeger door hem gezonden handschrift, bevattende de "Beschrijving van Sumatra's Westkust", terwijl, met diezelfde bestemming, worden toegezonden: van Bazel's "Radicale beschrijving van Sumatra's Westkust", het uittreksel uit de boeken en papieren van de Haagsche Bezoigne, benevens het tweede deel van het verslag van Mr. Jan Schreuder, Directeur van Souratte, (1751), Gouverneur van Ceilon, en later Raad van Indië.

Overeenkomstig het voorstel van den Voorzitter wordt besloten den heer Wttewaall voor zijn geschenk den dank der Vergadering aan te bieden, en de handschriften, om bericht en raad, in handen te stellen van den heer Kielstra.

4.0. eene missive van den heer C. E. P. Pauwels, Notaris te 's Gravenhage, van 26 Februari ll., waarbij wordt aangeboden een extract uit het testament van wijlen den heer P. J. B. C. Robidé van der Aa, bevattende eene beschikking ten behoeve van de Bibliotheek van het Instituut, waarvan door den Secretaris reeds mededeeling werd gedaan in de jongste Algemeene Vergadering van den 26 Februari ll.

$\mathrm{Na}$ eenige gedachtenwisseling wordt de Secretaris, overeenkomstig zijn voorstel, gemachtigd te zijner tijd het legaat te aanvaarden.

50. eene missive van het lid Dr. H. Breitenstein, officier van gezondheid le klasse, te Kotta Radja, houdende verzoek de uitgaven van het Instituut tot nader bericht hem niet te willen doen toekomen. Aangeteekend.

60. eene missive van het lid J. E. de Meijier, houdende bericht van zijn aanstaand vertrek naar Nederlandsch-Indië, met verzoek alle voor hem bestemde boekwerken naar Batavia te willen opzenden. Aangeteekend. 
70. missives van de heeren mr. P. J. G. van Diggelen, Dr. A. C. Oudemans Jzn., en van Prehn, waarbij zij berichten tot hun leedwezen het hun aangeboden lidmaatschap van het Instituut niet te kunnen aanvaarden.

80. missives van de heeren Jhr. mr. C. J. van Beresteijn, Bonn, P. R. Bos, H. G. Boumeester, Bon Brantsen van de Zijp, J. V. Brouwer, G. Brunner, J. Werumeus Buning, J. H. de Bussy, Coblyn, W. Cool, I. J. Dermout, J. P. C. Hartevelt, Gijsberti Hodenpijl, Jhr. mr. A. P. C. van Karnebeek, D. F. van der Pant, C. J. W. Ramann, W. J. van Welderen Baron Rengers, Baron G. Rosenthal, van Schermbeek, inr. J. P. Smeele, W. P. van Stockum Jr., F. C. Tromp, D. Visser van Hazerswoude, Mr. A. C. Wesenhagen en Mr. W. A. P. Th. Winckel, allen houdende kennisgeving van de aanvaarding van het lidmaatschap van het Instituut.

90. eene missive van Prof. F. Blumentritt, te Leitmeritz (Bohemen), houdende mededeeling van de aanvaarding zijner benoeming tot buitenlandsch lid, onder dankbetuiging voor de hem bewezen onderscheiding.

De missives sub 70-90 worden voor kennisgeving aangenomen.

De Secretaris herinnert aan het in de Bestuursvergadering van Januari jl. genomen besluit tot toekenning van eene subsidie aan den heer Dr. J. J. M. de Groot tot een bedrag van $f 1000$, welke som niet kan worden gekweten uit het beschikbaar kasgeld, waarom reeds $\mathrm{nu}$ moet worden overgegaan tot het gebruik maken van de door de laatste Algemeene Vergadering aan het Bestuur verleende machtiging tot het aangaan eener leening. Daar een der Bestuursleden zich bereid heeft verklaard evengenoemd bedrag in leen te verstrekken, wordt het voorstel gedaan van dat aanbod gebruik te maken. Dienovereenkomstig wordt besloten en de Penningmeester gemachtigd het noodige te verrichten ten einde den heer de Groot in het genot te stellen van de subsidie, waarvan de toekenning hem zal worden medegedeeld.

Ter tafel wordt gebracht een schrijven van Commissarissen, van 1 Februari 1887, no. B/135, waarbij wordt aangeboden: $a$. de verantwoording van hun geldelijk beheer over $1886 ; b$. eene opgaaf 
van de leden die achterstallig zijn in de betaling hunner contributie; $c$. de lijst der Indische leden, met opgaaf van woonplaats en aanteekening, welke leden tijdelijk in Europa met verlof zijn; $d$. eene opgaaf van leden die met verlof in Nederland zijn; $e$. eene opgaaf van de leden, die in Nederland betalen; $f$. eene opgaaf van de leden die met 1 Januari 1887 van de ledenlijst werden afgevoerd; en eindelijk $g$. eene opgaaf van de in 1886 bijgekomen leden.

Een en ander wordt in handen gesteld van den Secretaris en Penningmeester, met opdracht in de volgende vergadering het Bestuur daaromtrent te dienen van consideratiën en advies.

Overeenkomstig het voorstel van Commissarissen wordt tot lid van het Instituut aangenomen de heer A. A. L. J. Rouijer, predikant te Banda.

Commissarissen deelen in hun meergemeld schrijven nog mede, dat de heer H. M. La Chapelle, hoofdcommies ter Algemeene Secretarie, naar aanleiding van een tot hem gericht verzoek (referte aan no. 7 van hun schrijven van 11 Mei 1886 , no. B 129) medegedeeld heeft dat, naar zijne meening, zeer voldoende stof aanwezig is om voor Indië een Lapidarium samen te stellen, niet minder belangrijk en waarschijnlijk van veel grooteren omvang dan het "Lapidarium Ceylanicum." Reeds werden eenige gegevens door hem bijeengebracht en meerdere grafsteenen ontdekt, die her en der verspreid zijn. Het vervaardigen van nauwkeurige af beeldingen zal aan deskundige handen moeten worden toevertrouwd en ter bekoming van materiaal uit andere plaatsen zal de hulp van meerdere daarvoor geschikte personen moeten worden ingeroepen. Dat alles brengt niet onaanzienlijke kosten mede. Mocht het Instituut genegen zijn ze te dragen, dan is de heer La Chapelle bereid den arbeid op zich te nemen, en zou hij gaarne voorloopig de beschikking willen erlangen over een crediet van $f 500$, waarvan door hem naar gelang der behoefte zal worden gebruik gemaakt.

Tegen de inwilliging van dat verzoek bestaat bij Commissarissen geen bezwaar; en wanneer het Instituut de uitgaaf van een Indisch Lapidarium wil op zich nemen, meenen zij in overweging te moeten geven onder bovenstaande voorwaarde den heer La Chapelle tot de samenstelling er van te doen vitnoodigen.

Met belangstelling wordt van deze mededeeling van Commissarissen door de Vergadering kennis genomen, en is zij eenparig van oordeel 
dat de samenstelling van een Indisch Lapidarium alleszins wenschelijk is en aan geen bekwamer en ijveriger handen kan worden toevertrouwd; doch, waar reeds nu voor de voorbereidende werkzaamheden de beschikking wordt gevraagd over een crediet van $f 500$, verwacht men, dat de kosten, die voor den verderen arbeid en vooral voor de uitgave daarvan zullen gevorderd worden, vrij aanzienlijk zullen zijn en de draagkracht van het Instituut, althans op dit oogenblik, verre te boven gaan, waarom, overeenkomstig het voorstel van den Voorzitter, besloten wordt aan Commissarissen mede te deelen, dat, hoezeer ook het denkbeeld tot samenstelling van het bedoelde werk en opdracht daarvan aan den heer La Chapelle der Vergadering zeer toelacht en bij haar instemming vindt, het Instituut echter met het oog op de vele uitgaven, die het voor andere doeleinden moet bestrijden, bezwaar moet maken de vereischte ondersteuning te verleenen, althans voor het oogenblik; zullende inmiddels de zaak niet van de agenda worden afgevoerd, met uitnoodiging aan Commissarissen om, zoo mogelijk, eene nadere raming van de eventueele kosten van den te leveren arbeid en de uitgave daarvan te willen verstrekken.

Bij schrijven van 8 Maart jl. deelt de heer Martinus Nijhoff mede, dat Dr. B. F. Matthes, daarin gesteund door Prof. G. K. Niemann, eene nieuwe uitgave wenscht te doen verschijnen van zijn werkje: "Over de Wadjorezen met hun handels- en scheepswetboek", waarvan de eerste druk in 1869 bij de firma Hartrop te Makassar het licht zag. Met het oog op de onkosten die vrij hoog zijn wegens den in het werkje voorkomenden Boegineeschen tekst en het groote aantal verschillende geaccentueerde letters in de tranrscriptie der Boegineesche woorden, gevoegd bij het uiterst beperkte debiet, dat het werk te wachten staat, zou eene nieuwe uitgave slechts mogelijk zijn, als zij wordt gesubsidieerd. In overleg met Dr. Matthes wordt daarom de vraag gedaan: 10. of het Instituut geneigd is het werk geheel voor zijne rekening tc doen herdrukken; of 20. zoo daartegen bedenking mocht bestaan, dien herdruk mogelijk te maken door eene subsidie van $f 150$.

$\mathrm{Na}$ eenige gedachtenwisseling over dit voorstel vereenigt de Vergadering zich eenparig met het gevoelen van den Voorzitter, om den heer Nijhoff mede te deelen, dat men, gaarne de waarde erkennend van des heeren Matthe's werk, niet alleen voor de Boegineesche taalstudie maar ook voor de ethnologie van Celebes, 
juist met oog daarop meent een eventueelen herdruk van het werk gerust aan de particuliere industrie te mogen overlaten, die ook de eerste uitgave voor haar rekening heeft bezorgd zonder eenige tusschenkomst of financieëlen steun van het Instituut.

Ter tafel wordt gebracht:

10. een schrijven van het Bestuur der Vereeniging voor oudheid-, land-, taal- en volkenkunde te Djokjokarta, van 1 Jan. jl., ten geleide van een stel afdrukken van teekeningen van beelden, enz. van de Tjandji's Prambanan en Sari in Djokjokarta;

20. een nader schrijven van evengemelde Vereeniging van 25 Januari jl., waarbij zij, onder kennisgave van het bestaan harer bij besluit van 27 October 1886, no. 10 (Stbl. no. 196) door de Regeering als rechtspersoon erkende instelling, en onder overlegging van een afschrift harer Nota aan de Regeering, meent zich tot het Instituut te mogen wenden met het dringend verzoek om zijne medewerking, en, zoo mogelijk, ook zijn geldelijken steun bij haren arbeid te verleenen, te meer daar het, zoo de Regeering haar al mocht kunnen bijstaan, met het oog op de betrekkelijk geringe som voor wetenschappelijke doeleinden toegestaan, bijna zeker is, dat die bijstand voor de in de Nota genoemde behoeften geenszins geheel voldoende zal zijn.

De bij dit schrijven aangeboden Nota luidt als volgt:

"t Ondervolgende voorstel zou reeds voor vele maanden der Regeering aangeboden zijn, indien onze pogingen om nog in ' $t$ afgeloopen jaar geldelijken steun van de Regeering of van 't Bataviaasch Genootschap van Kunsten en Wetenschappen te erlangen, niet zonder gevolg waren gebleven.

"Thans meenen wij daarop terug te mogen komen, te meer daar het een zaak geldt, die der Regeering, die reeds jaren geleden, het groote werk over den wereldberoemden en eenigen Båråboedoer. deed uitgeven en ook in 't buitenland verspreiden, zeer ter harte moet gaan.

"Vooraf een woord over onze vereeniging en haar arbeid.

"Zij werd in Juli 1885 opgericht en erlangde bij Gouvernementsbesluit van 27 October A. P. No. 10 (Staatsblad No. 196) uw erkenning als rechtspersoon.

"Zij heeft gedurende dien tijd de tjandis Parambanan, Kalibëning, Plahosan en Sari van puin bevrijd en toegankelijk gemaakt, onderzocht en zooveel mogelijk in kaart gebracht en afgebeeld en daarbij voor de wetenschap zeer belangrijke resultaten verkregen. 
"De vraag of de tjandi Parambanan boeddhistisch of Sivaïtisch was, is door 't ontblooten van den inhoud zijner verschillende tempels, waarover een uitvoerig tijdschriftartikel in bewerking is, in den laatsten zin beslist geworden.

"I ichtafdrukken van teekeningen van de daar gevonden zeer schoone beeldwerken, zijn aan 't Bataviaasch Genootschap en andere Nederlandsche wetenschappelijke vereenigingen toegezonden.

"Onze vereeniging heeft dien arbeid geheel uit eigen middelen bekostigd, maar, zoo die middelen in den aanvang ruimer vloeiden en daardoor toen toereikend waren, thans zijn zij tot de maandelijksche kontributiën ( $\mathrm{ad} f 1$ ) en enkele schenkingen der leden, en dus tot een ontoereikend bedrag teruggebracht, waarom de vereeniging zich ondanks haar beteren wil verplicht ziet haar arbeid te beperken en veel langzamer dan haar lief is voort te gaan, terwijl nieuwe ontdekkingen, onder anderen van een onbekende Sivaïtische tempelgroep nabij den Goenoeng Idjo in 't Zuidergebergte, bezuiden Kalasan en Parambanan, en die vermoedelijk geheel ongerepte putten bevat, tot verdubbelden arbeid uitlokken, en 't onderzoeken van nog vele andere, ook boeddhistische tempels, evenals 't tot stand brengen van een museum, voor welke werkzaamheden de vereeniging in dit jaar een f 3000 zou behoeven, alleen verdaagd moet worden omdat dit onze financieële krachten ver te boven gaat.

"Intusschen is 't groote werk door Dr. Leemans op last der Regeering over den Båråboedoer uitgegeven, tengevolge van de ontdekking, door onzen oud-voorzitter IJzerman, van een geheel onbekende reeks basreliefs langs den door't omsluitend terras bedekten voet van den buitenmuur onvolledig geworden.

"Die basreliefs zijn vermoedelijk alle even gaaf bewaard en met verklarende opschriften voorzien, waardoor hun wetenschappelijke belangrijkheid in zeer groote mate toeneemt, te meer daar tot dus ver nog geen enkele beschreven steen, hoe gewenscht ook, op of nabij den Båråboedoer gevonden was. (*)

"Een beschrijving en afbeelding van die basreliefs en vooral van

$\left(^{*}\right)$ Een enkele proef van de belangrijkheid van zulke opschriften.

Beelden met samengevouwen handen worden door Europeanen volgens Europeesche opvatting veelal verkeerdelijk als aanbiddend beschreven. Toch beteekenen die samengevouwen handen niets anders dan de hulde der nog altijd gebruikelijke Sembah. Welnu, boven een der drie ontbloote basreliefs, menschen met gevouwen handen voor een tempel voorstellend, las $\mathrm{Dr}$. Brandes in oud-javaansch: huldiging van den Caitija (tempel aan Adi boeddha of een der dhijani boeddha's gewijd). Geen aanbidding dus, 
die zeer veel belovende opschriften kan 't onvolledige van Leemans' arbeid aanvullen en tot een beter begrip van de beteekenis van den tempel en van veel, dat nog duister is of slechts onzekere gissingen wekt, leiden.

"En dat werk mag urgent genoemd worden, omdat het moeielijker, langduriger en vooraal kostbaarder wordt, naarmate de verweerde muren, die nu reeds op verschillende plaatsen ingezakt zijn, door indringend regenwater ondermijnd, door aardbevingen geschokt en door woekerplanten verteerd, meer uiteen wijken en dreigen in te storten, zoodat na korteren of langeren tijd de ontblooting dier beeldwerken onuitvoerbaar zal worden zonder eerst den bovenmuur af te breken.

"t' Is daarom van belang, dat die blootlegging en afbeelding niet verdaagd, maar zoo spoedig mogelijk volbracht worde.

"Volgens 't oordeel onzer bouwkundige bestuursleden kan die blootlegging zonder gevaar voor den buitenmuur 't best achtereenvolgens geschieden, terwijl telkens 't ontbloote en afgebeelde met de steenen, die daarnaast voor de volgende ontblooting worden weggenomen, weder bedekt wordt.

Op die wijze worden alle basreliefs achtereenvolgens in den kortst mogelijken tijd ontbloot en weder afgesloten, zonder den buitenmuur in gevaar te brengen en eindelijk de laatst ontbloote met de 't eerst weggenomen steenen gedekt.

"'t Kan daarbij wenschelijk blijken deu buitenmuur op enkele plaatsen tijdelijk te stutten.

"Blijvend blootleggen zou 't aanbrengen van belangrijke blijvende steunwerken noodig maken en daardoor grooter kosten veroorzaken.

"Volgens de raming van ons bestuurslid, den Ingenieur Hubenet, zullen voor dezen arbeid hoogstens 150 werkdagen van 8 uren benoodigd zijn, al of niet vermeerderd met den tijd, die ' $t$ afbeelden der beeldwerken vorderen zal.

"Als volgens zijn werkplan de arbeid aan de vier zijden van den tempel gelijktijdig aangevangen en voortgezet wordt, kan ' $t$ fotografeeren op de eene plaats en 't ontblooten en dichtleggen op andere plaatsen gelijktijdig geschieden en daardoor tijd en geld bespaard worden.

"De gansche reeks basreliefs op 300 stuks van een M. lang en 0.30 hoog stellend, en volgens ons medelid Cephas een half uur nemend voor 't vervaardigen en ontwikkelen van elke Cliché (drooge 
gelatine plaat) zouden voor het fotografeeren van alle basreliefs 150 uren of 30 werkdagen van 5 uren gevorderd worden.

"'t Uit de hand teekenen zou natuurlijk veel meer tijd en geld kosten en, zooal volkomen nauwkeurige, toch minder vertrouwde afbeeldingen geven. Een fotogram moet juist zijn en de drie blootgelegde basreliefs zijn zoo goed bewaard, dat aanvulling onnoodig is. $(*)$

"Het geheele werk zou dus in zes maanden volbracht kunnen worden, of in zooveel minder tijd, wanneer met meer arbeiders op meer plaatsen tegelijk gewerkt werd.

"De kosten van 't verzetten van $1 \mathrm{M}^{3}$. behouwen steen met ons bestuurslid Hubenet op 50 centen ramend, zou de geheele arbeid, waarbij $\pm 7200 \mathrm{M}^{3}$ steen verplaatst moeten worden, $f 3600$ kosten.

"t Aantal Clichés op 300 stellend en $f 10$ voor 't vervaardigen en 't afstaan in vollen eigendom van elke Cliché aan de vereeniging (of haar geldschieter) zouden de Clichê's $f 3000$ kosten.

"Aannemend dat het gansche werk zes maanden tijd vordert en de beide personen die met de leiding van den arbeid en 't fotografeeren belast worden, voor tijdverlies, arbeid, reis- en verblijfkosten een maandelijksche toelage genieten van $f 250$ ieder, dan zouden daarvoor $500 \times 6=f 3000$ en dus voor alle uitgaven te samen $f 9600$ hoogstens benoodigd zijn.

"Ons medelid de hoffotograaf Cephas, wiens uitstekende arbeid een waarborg is voor de goede uitvoering der Cliché's, zou, indien hij op bovengenoemde voorwaarden met den fotografischen arbeid belast werd, daarvoor aan Z. H. den Sultan verlof moeten vragen en zijn atelier te Jogjokarta tijdelijk sluiten.

"Werd ons lid H. L. Leijdie Melville, de tijdelijk nu reeds door de Regeering aan ons afgestane teekenaar bij den dienst der Staatsspoorwegen, met de leiding van den overigen arbeid belast, dan zou, terwijl zijn ambtenaarstractement doorging, de bovenbedoelde toelage van $f 250$ 's maands met het bedrag van zijn tractement verminderd worden.

"Dat de hoofdleiding en de kontrôle van den arbeid in goede handen zouden zijn, terwijl wij den Hoofd-Ingenieur Schippers en

$\left(^{*}\right)$ Dit werd geschreven in Juni A. P. Voor nu ongeveer twee maanden bezochten twee onzer bestuursleden den bouwval en ontwaarden tot hun bevreemding, dat er een vier of vijftal basreliefs meer blootgelegd waren. Wellicht niet met de noodige zorg voor 't behoud van 't geheel. Wij vernemen, dat dit door een belangstellend Nederlandsch toerist voor eigen rekening geschied is met voorkennis van den Resident van Kadre, maar tevens dat dit niet meer zal worden toegestaan. 
den Ingenieur Hubenet onder onze bestuursleden tellen, behoeft geen betoog.

"Indien de Regeering zich met deze beschouwingen mocht kunnen vereenigen, overtuigd van de wenschelijkheid om 't eenmaal door haar begonnen en sedert onvolledig geworden werk, dat ook in ' $t$ buitenland gewaardeerd wordt en onzen Nederlandschen naam eer aandoet, te voltooien, dan meenen wij ons gerechtigd tot het eerbiedig verzoek dat zij onze vereeniging tot de uitvoering van den voorgestelden arbeid machtige en ons de daartoe benoodigde gelden van vermoedelijk hoogstens $f 9600$ toesta, waarvoor zij eigenares zou worden van de volledige kollektie hoogst belangrijke en vooral door de opschriften der basreliefs voor de voltooiing van Leeman's boekwerk onmisbare Cliché's."

Naar aanleiding van een en ander worden door den Voorzitter en den Secretaris eenige inlichtingen verstrekt, waaruit blijkt, dat de zaak o. a. ook aanhangig is gemaakt bij de Koninklijke Akademie van Wetenschappen te Amsterdam, in wier eerstvolgende vergadering men verwacht dat de heer IJzerman de noodige nadere mededeelingen zal doen omtrent den arbeid en de plannen der zusterinstelling te Djokjokarta, waarom, overeenkomstig het voorstel des Voorzitters, besloten wordt de behandeling van het voorstel van evengemelde Vereeniging te verdagen.

De heer Bool vestigt de aandacht der Vergadering op een tweetal door den oud O. I. predikant C. A. L. van Troostenburg de Bruyn vervaardigde handschriften, waarvan het eene bevat een biographisch woordenboek van $O$. Ind. predikanten en het ander eene alphabetische naamlijst van $O$. Indische Krankbezoekers, het eerste 33, het laatste 7 cahiers omvattend, terwijl \pm 1500 namen in het eerste handschrift worden vermeld. Daar de firma Brill ze in April of Mei a. s. te koop zal aanbieden, vraagt de heer Bool of het niet raadzaam zou zijn, dat het Instituut in het bezit daarvan kwam.

Met het oog op het vergevorderd uur wordt de behandeling dezer zaak uitgesteld, waarna de Vergadering door den Voorzitter gesloten wordt. 


\section{2ste BESTUURSVERGADERING}

GEHOUDEN 16 APRIL 1887.

Tegenwoordig de heeren Kern (Voorzitter), de Groot (Penningmeester), Kielstra, Schlegel, Snouck Hurgronje, Riedel, Martin en Wijnmalen (Secretaris). Afwezig, met kennisgeving, de heeren Bool, Humme en Niemann.

De notulen van het verhandelde in de vorige Vergadering worden gelezen en goedgekeurd.

De Voorzitter deelt mede, dat van den Ondervoorzitter, mr. W. Ridder van Rappard, een schrijven is ingekomen dd. 16 April jl., waarbij hij kennis geeft, dat hij, het om meer dan eene reden wenschelijk achtende zich terug te trekken als Lid van het Bestuur, besloten heeft zijn ontslag als zoodanig te nemen, met verzoek zijn naam te willen afvoeren van de lijst der Bestuursleden, onder verzekering tevens van zijne belangstelling in den bloei van het Instituut.

Verrast door dit schrijven en het betreurende, besluit de Vergadering, overeenkomstig het voorstel des Voorzitters, eenparig, den Ondervoorzitter haar leedwezen over de haar gedane mededeeling te betuigen, met dringend verzoek, zoo mogelijk, alsnog op zijn besluit te willen terugkomen.

Door den Secretaris wordt opgave gedaan van de voor de Bibliotheek verworven aanwinsten, 't zij door aankoop, 't zij door geschenken, onder mededeeling tevens van den ontvangst van eene missive van den Minister van Marine van 9 April jl. Letter Secretarie, No. 58, waarbij, ten vervolge, wordt toegezonden een exemplaar van het "Jaarboek voor de Koninklijke Nederlaudsche Zeemacht 1885/6," door zijn Departement vitgegeven.

Plaatsing der boekwerken in de Bibliotheek, onder dankzegging aan de inzenders.

Wordt vervolgens medegedeeld, dat zijn ontvangen:

10. eene missive van den heer J. Doorman, te 's Gravenhage, houdende kennisgeving van het overlijden van zijn vader J. D. Doorman, in leven lid van het Instituut. 
20. eene missive van de familieleden en vrienden, houdende kennisgeving van het overlijden, op den 17 Maart 1887, in den ouderdom van 77 jaren, van den heer P. E. L. Favre, in leven hoogleeraar in de Javaansche en Maleische talen aan de École nationale des langues orientales vivantes en buitenlandsch lid van het Instituut, te Parijs.

30. missives van de heeren Dr. H. F. C. ten Kate jr. en J. C. Th. Kroesen, te 's Gravenhage, en W. A. Arriëns, kapitein ter zee, te Rotterdam, allen houdende kennisgeving van de aanvaarding van het lidmaatschap van het Instituut.

40. eene missive van het lid Dr. van Riemsdijk, te Fort de Kock, houdende kennisgeving dat hij in de eerste dagen van Mei a. s. naar Nederland vertrekt met verzoek de voor hem bestemde drukwerken voorloopig te willen doen toekomen aan den heer Boonacker, luitenant-kolonel der genie, te Utrecht.

Al deze missives worden voor kennisgeving aangenomen.

Ter tafel wordt gebracht een schrijven van Commissarissen, te Batavia, dd. 4 Februari jl. No B/136, waarbij wordt medegedeeld dat aan den heer D. Gerth van Wijk op diens verzoek een tweejarig verlof naar Nederland is verleend en dat hij in verband daarmede op 1 April a. s. zijn commissariaat wenscht neder te leggen. Ter voorziening in de daardoor te ontstane vacature hebben Commissarissen gemeend niet beter te kunnen doen dan zich te wenden tot Dr. J. Brandes, met het verzoek den heer Gerth van Wijk te willen vervangen, waartoe hij zich na eenig beraad bereid verklaarde.

Overeenkomstig het voorstel des Voorzitters wordt eenparig besloten de keuze van Commissarissen goed te keuren en wordt Dr. J. Brandes mitsdien tot Commissaris van het Instituut benoemd, van welke keuze zoowel aan den benoemde als aan Commissarissen mededeeling zal worden gedaan.

Is ingekomen een missive van de Directie van de Société archéologique de Bordeaux, dd. 28 Maart jl, houdende verzoek tot ruiling van wederzijdsche uitgaven. Dienovereenkomstig wordt, na eenige gedachtenwisseling, besloten.

Door den heer M. Nijhoff is, onder dagteekening van 12 April jl., een schrijven ingezonden, waarbij hij, naar aanleiding van de in de 
laatste aflevering der Bijdragen medegedeelde onderhandelingen met de firma E. J. Brill over de uitgave eener vertaling van Montero's werk over de Philippijnen, in de eerste plaats zijne bevreemding te kennen geeft, dat het Bestuur zich niet tot hem, den uitgever van het Instituut, gewend heeft en zijn advies niet is ingewonnen. En wat voorts de zaak zelve aangaat, komt het hem voor, dat eene uitgave, waaraan de hoogleeraren Kern en Wilken hun naam willen verbinden, een niet al te groot, $\mathrm{ja}$, misschien in het geheel geen offer van de zijde van het Instituut zal vorderen. Mocht het Bestuur in deze zaak nog belang stellen in het advies van zijn uitgever, dan zal hij, als zoodanig, het zich ten plicht rekenen in het belang van het Instituut en de Indologische wetenschap aan dit verlangen te voldoen.

$\mathrm{Na}$ eenige gedachtenwisseling wordt besloten den Secretaris te machtigen, den heer Nijhoff de noodige inlichting te geven omtrent de met de firma Brill gevoerde onderhandelingen, waartoe het initiatief niet door het Bestuur, maar door derden werd genomen.

Onder herinnering aan het in de vorige vergadering gedaan en toen aangehouden voorstel tot aankoop van een tweetal handschriften betreffende de Indische kerkgeschiedenis, afkomstig van de predikant C. A. L. van Troostenburg de Bruyn, vraagt de Secretaris daaromtrent het oordeel van het Bestuur, daar de verkoop dier hss. Woensdag den 11 Mei a. s. bij de firma Brill zal plaats hebben.

$\mathrm{Na}$ eenige gedachtenwisseling wordt de Secretaris met meerderheid van stemmen gemachtigd tot den aankoop der bedoelde handsehriften over te gaan, waartoe hem een crediet van hoogstens $f 75$ wordt toegestaan.

Door den heer Kielstra wordt het volgend rapport uitgebracht: "Naar aanleiding van het voorstel, door het bestuurslid van Deventer en mij in de Bestuursvergadering van 12 Februari jl. gedaan, heeft de heer B. W. Wttewaall van Wickerburgh aan het Instituut afgestaan:

10. de Radicale Beschrijving van Sumatra's Westkust, door van Basel (1761);

20. een handschrift, bevattende een uittreksel uit de boeken en papieren der Haagsche Bezoigne, omstreeks 1748 samengesteld; en 30. de tweede helft - de eerste helft is verloren geraakt - van 
eene memorie, in 1750 ten behoeve van zijnen opvolger opgesteld door J. Schreuder, aftredend directeur van Suratte.

"Deze handschriften vormen te zamen ongetwijfeld eene belangrijke aanwinst voor onze verzameling.

"Dat van Van Basel is - zooals wij reeds in de evenbedoelde vergadering opmerkten - voor verreweg het grootste gedeelte gepubliceerd; het zal thans nog goede diensten kunnen bewijzen, wanneer het vroeger besproken handschrift voor de pers wordt gereed gemaakt. Doch van eene nieuwe uitgaaf van Van Basel's arbeid kan uit den aard der zaak thans wel geene sprake meer zijn, hoewel het zeker nog meermalen geraadpleegd zal worden.

"Het tweede handschrift, bovenbedoeld, bevat tal van wetenswaardige bijzonderheden omtrent al de kantoren waar de O. I. Compagnie handel dreef, en omtrent dien handel-zelven. Het zal hem, die van een en ander eene studie wenscht te maken, ongetwijfeld in vele opzichten een goede wegwijzer zijn; doch de uitgaaf van dit handschrift vanwege het Instituut durf ik niet aanraden. Daarvoor heeft het, naar mijne bescheiden meening, niet genoeg algemeen belang voor geschiedenis, taal of land- en volkenkunde; te meer, $\mathrm{nu}$ betrekkelijk weinige jaren te voren (1726) Valentijn reeds haast alles wat toen uit een historisch en geographisch oogpunt bekend was, bijeen verzameld had.

"Het derde handschrift eindelijk acht ik het minst belangrijk en in geenen deele voor eene eventueele uitgaaf aan te bevelen, waarvan trouwens, aangezien de eerste vier hoofdstukken ontbreken, toch bezwaarlijk sprake zou kunnen zijn. Het bevat een overzicht van de wijze waarop 't "Compagnies-comptoir" te Suratte werd bestuurd, van den daar gedreven handel, van de daaraan verbonden administratiën, van den toestand der Compagniesgebouwen, van het personeel der Compagnie te Suratte aanwezig en van de daar verkregen of te verkrijgen winsten, enz.

"Ik neem derhalve de vrijheid voor te stellen, de drie thans ontvangen stukken bij onze handschriften-verzameling neder te leggen, zijnde den schenker reeds de dank van het Bestuur voor zijne opnieuw betoonde belangstelling aangeboden."

Onder dankbetuiging aan den Rapporteur, stelt de Voorzitter voor zich met diens conclusie te vereenigen. Dienovereenkomstig wordt besloten.

Door de welwillendheid des heeren Serrurier is den Secretaris toegezonden een $\mathrm{nr}$. van de N. Rotterdamsche Courant van 8 
April, eerste blad, waarin, onder de opgaven der geschenken aan de Rotterdamsche Diergaarde voorkomt: "een stuk steen van een der Boeddhabeelden der tempels Boeroe-Boedhoer." Hoewel men der Diergaarde die aanwinst niet misgunt, kan het medegedeelde weder als een staaltje gelden van de wijze waarop in Indië met de oudheden wordt omgesprongen. Daar dit bericht zijn waarde hebben kan als bijlage in het dossier omtrent de conserveering der Hindoemonumenten, welke aangelegenheid door het Instituut wordt ter harte genomen, stelt de Secretaris voor het in het archief te deponeeren, ten einde ter gelegener tijd daarop de aandacht te vestigen.

Dienovereenkomstig wordt besloten.

Zoowel naar aanleiding van het in de jongste Algemeene Vergadering gedaan voorstel, dat er vanwege het Instituut eene wetenschappelijke expeditie worde ondernomen, als met het oog op de mislukte pogingen van het Ned. Aardrijkskundig Genootschap om zijnerzijds een onderzoekingstocht in onze overzeesche bezittingen te organiseeren, wordt door den Secretaris de vraag geopperd, of het niet raadzaam zou zijn dat ook hier te lande, op het voorbeeld van Frankrijk, eene "Commission des missions scientifiques" worde in het leven geroepen. Werd daarop reeds in de Tweede Kamer der StatenGeneraal gezinspeeld bij de beraadslagingen omtrent het voorstel tot toekenning van een subsidie voor een onderzoekingstocht naar Nieuw-Guinea, de Secretaris treedt in uitvoerige beschouwingen zoowel omtrent de samenstelling als den werkkring en de resultaten van den arbeid van evèngemelde Commissie.

$\mathrm{Na}$ eenige gedachtenwisseling wordt besloten de heeren Martin, Riedel en den Secretaris uit te noodigen de zaak nader te overwegen en in eene volgende vergadering daaromtrent het Bestuur te dienen van consideratiën en advies.

Door den Voorzitter wordt de andacht der Vergadering gevestigd op het feit, dat, terwijl van de recensie-exemplaren der Bijdragen, aan de buitenlandsche bladen toegezonden, door deze telkens nota wordt genomen door het geven van min of meer breedvoerige overzichten, dit niet het geval is met sommige Nederlandsche bladen, met name het Algemeen Handelsblad, de N. Rotterdamsche Courant en het Dagblad van 's Gravenhage, waaraan mede telkens exemplaren worden uitgereikt. Hij stelt daarom voor de toezending daarvan aan die bladen te staken.

Dienovereenkomstig wordt besloten.

5e Volgr. II. 
De Penningmeester deelt mede, dat hij de hem in de vorige vergadering om consideratie en advies ter hand gestelde rekening en verantwoording van Commissarissen te Batavia met den Secretaris heeft onderzocht. Tegen de goedkeuring daarvan bestaat geen bezwaar, waartoe hij dan ook het voorstel doet, onder dankbetuiging tevens aan Commissarissen voor hun financieel beheer.

Dienovereenkomstig wordt besloten.

Tot leden van het Instituut worden voorgesteld en aangenomen de heeren D. van Breda de Haan, te Leiden, Dr. P. Adriani, te Leeuwarden, David J. Samot te Rotterdam en M. M. Schepman, te Rhoon, bij Rotterdam, terwijl aan Commissarissen het verzoek zal worden gedaan het lidmaatschap aan te bieden aan Dr. Groneman, te Djokdjokarta.

Niets meer hierna aan de orde zijnde, wordt de vergadering door den Voorzitter gesloten.

\section{STE BESTUURSVERGADERING}

GEHOUDEN 21 MEI 1887.

Tegenwoordig de heeren Kern (Voorzitter), de Groot (Penningmeester), Schlegel, Snouck Hurgronje, Riedel, Martin, Bool, Humme, Niemann en Kielstra.

De President deelt mede, dat de Secretaris door ongesteldheid verhinderd is de vergadering bij te wonen, doch den heer Kielstra alle vereischte inlichtingen en bescheiden heeft gegeven.

Deze wordt diensvolgens uitgenoodigd het Secretariaat waar te nemen.

De notulen van het verhandelde in de voorgaande vergadering worden gelezen en goedgekeurd.

De $\mathrm{w}^{\mathrm{d}}$ Secretaris doet opgaaf van de voor de Bibliotheek des Institunts ontvangen boekwerken en handschriften.

Onder deze laatste komen voor de verzamelingen des heeren van 
Troostenburg de Bruyn, waarvan in de vorige vergadering sprake is geweest. Zij zijn op de openbare verkooping aangekocht voor de som van $f 75$. - en bevatten:

a. eene naamlijst in alph. orde der O. I. predikanten, proponenten, enz. (795 bladz. in 33 cahiers); en

b. idem van O. I. krankbezoekers (153 bldz. in 7 cahiers).

Van Teyler's Stichting, het Historisch Genootschap te Utrecht en het Departement of the Interior, United States Geological Survey zijn brieven van dankbetuiging voor de toezending der laatste aflevering der Bijdragen ontvangen.

Door de Société royale Belge de géographie is bij briefkaart medegedeeld, dat zij niet heeft ontvangen van de Bijdragen:

4 e volgreeks, $6 \mathrm{e}$ deel $1^{\mathrm{e}} \mathrm{stuk}$

$44^{e} \quad 3^{\mathrm{e}} " 3^{\mathrm{e}}$ en $4^{\mathrm{e}}$ stuk

5 e $" 10 " 3^{e}$ stuk.

Op haar verzoek om deze Bijdragen nog te zenden, wordt besloten daaraan zooveel mogelijk te voldoen.

Van den Directeur van 's Rijks museum van Natuurlijke historie is een voorstel ontvangen betreffende de ruiling der "Notes" dezer inrichting met de edita des Instituuts.

$\mathrm{Na}$ eenige gedachtenwisseling wordt besloten, genoemden Directeur dank te zeggen voor zijn welwillend aanbod, doch hieraan geen gevolg te geven, aangezien, naar vermeend wordt, bedoeld Tijdschrift niet past in het kader der werkzaamheden des Instituuts.

Van den heer M. Nijhoff is mededeeling ontvangen dat thans nog exx. onzer Bijdragen ter recensie worden gezonden aan de Revue coloniale internationale, Trübners Oriental Record, Litterarische Centralblatt, Deutsche Colonial Zeitung, Deutsche Rundschau, Das Ausland. Naar aanleiding van een door de redactie der Deutsche Litteratur-zeitung aan den heer Nijhoff gezonden schrijven wordt als het gevoelen der Vergadering uitgesproken, dat eene geregelde bespreking onzer edita niet verlangd wordt, alleen opgaaf van den inhoud. Wanneer deze geregeld vermeld wordt, kan de toezending ook aan de Litteraturzeitung voortgaan.

De vraag wordt gedaan of ook de Redactie van het Dagblad van Zuid-Holland en 's Gravenhage niet geregeld melding makt van den inhoud. In dat geval zou ook de toezending aan dit blad niet behooren gestaakt te worden. 
Van den heer Mr. W. Ridder van Rappard is, in antwoord op het hem gezonden schrijven, bij brief van 22 April de mededeeling ontvangen, dat hij, zeer gevoelig voor de welwillende gevoelens van het Bestuur en deze zeer op prijs stellend, echter tot zijn leedwezen niet aan het vereerend verzoek des Bestuurs kan voldoen en dus blijft volharden bij zijn wensch om als bestuurslid af te treden.

Dit schrijven voor kennisgeving aannemende, wordt besloten aan het einde der vergadering over te gaan tot de benoeming van eenen Onder-voorzitter ter vervanging van genoemden heer.

Van de hh. Beeger, Adriani, van Breda de Haan, Samot, Schepman en Kooiman is mededeeling ontvangen, dat zij het hun aangeboden lidmaatschap van het Instituut aanvaarden.

Aangenomen voor kennisgeving.

Van Commissarissen te Batavia is bericht ontvangen dat door hen met ingang van 1 Januari 1887 tot leden des Instituuts zijn benoemd de hh. H. A. Hijmans van Anrooy, Secretaris der residentie Oostkust van Sumatra, te Medan, en F. K. L. Storm van 's Gravesande, Controleur bij het Binnenl. Bestuur te Laboean, Deli. Goedgekeurd.

Commissarissen berichten daarbij dat verscheidene der in 1886 benoemde leden de edita niet hebben ontvangen.

Hieromtrent wordt opgemerkt dat eene dergelijke mededeeling, wanneer die niet vergezeld gaat van eene opgaaf der personen aan wie de edita niet gezonden zouden zijn, weinig baat. Zoodanige mededeeling is nu alleen ontvangen omtrent den heer Stemfoort, die thans, overeenkomstig zijṇ verzoek, zal beschouwd worden als met 1 Jan. 1887 als lid te zijn toegetreden.

Intusschen zal worden nagegaan of in 1886 aan alle nieuw benoemde leden de bijdragen wel naar behooren zijn afgezonzen.

Op voorstel van den Secretaris worden benoemd tot leden des Instituuts de hh. H. Altmann, ambtenaar ter beschikking te Cheribon en P. G. Schmidhamer, le luitenant der Infanterie te Amboina; op voorstel van het bestuurslid Riedel; de heer G. A. Kramp, te Amsterdam; op voorstel van het bestuurslid Niemann, de heer Dr. W. F. van Vliet Jr., leeraar aan het gymnasium te Delft.

Op voordracht van den President, naar aanleiding van een bij dezen ontvangen schrijgen van den heer Meyners d'Estrey, wordt 
tot correspondeerend lid van het Instituut benoemd de heer Xavier Brau de St. Pol-Lias.

Door de daartoe benoemde Commissie is een voorstel ingediend betreffende de oprichting eener Koloniale Bibliotheek, waarin de bibliotheken van het Indisch Genootschap en van het Instituut zouden worden opgenomen.

Overwegende dat de Secretaris, de heer Wijnmalen, die voor dergelijke regeling het initiatief heeft genomen en bedoeld voorstel heeft uitgewerkt, bij de bespreking bezwaarlijk zal kunnen worden gemist en er ongetwijfeld ook zelf prijs op zal stellen, in de gelegenheid te zijn aan die bespreking deel te nemen, wordt besloten de behandeling van dit voorstel tot eene volgende vergadering uit te stellen.

Omtrent de in eene vorige vergadering aangehouden voorstellen van de Vereeniging voor Oudheid-, Land-, Taal en Volkenkunde te Djokjokarta omtrent het onderzoek der Hindoe-monumenten worden door den President eenige inlichtingen gegeven, naar aanleiding waarvan besloten wordt aan de Vereeniging voornoemd te doen kennen, dat met reden kan worden verwacht dat de geldelijke hulp, door de Indische Regeering voor bedoeld onderzoek te verstrekken, wel voldoende wezen zal; te meer, nu deze, door het beschikbaar stellen van een bekwaam teekenaar, reeds het bewijs heeft gegeven het onderzoek der monumenten krachtig te willen bevorderen. Althans voorloopig wordt moreele of materieele steun van het Instituut mitsdien onnoodig geacht.

Van Commissarissen is, bij brief van 23 Maart $1887 \mathrm{n}^{\mathrm{r}}$. B/137, ontvangen een door den Controleur Helfrich samengestelde beschrijving van de afdeeling Kroë (Bengkoelen) met schetskaart en teekeningen. Dit stuk wordt in handen gesteld van eene Commissie, bestaande uit de hh. Martin en Niemann.

Op het verzoek van Commissarissen om t. z. t. mededeeling te ontvangen van het den heer Helfrich toekomend honorarium zal worden gelet, zoodra bedoelde beschrijving mocht zijn gepubliceerd.

Naar aanleiding eener correspondentie, door den heer Harrebomée met den Secretaris gevoerd, deelt het bestuurslid Niemann mede dat de door dien heer geleverde Oeloesche studiën onvoldoende zijn, ook na de daaraan door hem aangebrachte verbeteringen. De heer Niemann 
acht de studiën noch volledig, noch belangrijk, noch vertrouwbaar genoeg om eene uitgaaf van Instituutswege aan te bevelen.

De heer Snouck Hurgronje deelt mede dat de hoogleeraar Wilken evenals de heer Niemann reeds vroeger eene ongunstige meening had vitgesproken over de Oeloesche woordenlijst.

$\mathrm{Na}$ eenige discussie vereenigt het Bestuur zich met het uitgebracht advies en besluit het den heer Harrebomée mede te deelen dat zijne geschriften voor opneming in de Bijdragen minder geschikt geoordeeld worden.

De Secretaris deelt daarop mede, dat hij van den heer Harrebomée het verzoek heeft ontvangen om, ingeval het Bestuur tot dit besluit komen mocht, mede te deelen dat genoemde heer aan zijne eer verplicht is voor het lidmaatschap des Instituuts te bedanken.

De heer Harrebomée wordt diensvolgens van de ledenlijst afgevoerd.

De Secretaris deelt, namens den heer Wijnmalen, mede dat de 3e afl. der Bijdragen ter perse is.

Het bestuurslid Kielstra biedt, ter plaatsing in de Bijdragen, aan een opstel over "onze kennis van Sumatra's Westkust omstreeks de helft der achttiende eeuw", hoofdzakelijk samengesteld uit de handschriften, bij het Instituut berustende en van den heer Wttewaall ontvangen.

Hij deelt daarbij mede dat, zooals de heer H. C. Canne, oudGouverneur van Sumatra's W. K. hem schreef, de kennis van tal van bijzonderheden omtrent vroegere toestanden en verhoudingen, die tot dusver niet beschreven waren en in bedoeld opstel voorkomen, voor de ambtenaren ter Sumatra's W. K. van veel belang zou zijn, zoodat het wellicht wenschelijk ware aan den Minister van Koloniën de vraag te stellen of de Regeering afdrukken van het opstel wenscht te ontvangen ter verspreiding onder de ambtenaren in genoemd gewest.

Besloten in dezen geest te handelen, wanneer tot den druk wordt overgegaan.

Thans overgaande tot de benoeming van een Onder-voorzitter, wordt door de Vergadering bij meerderheid van stemmen daarvoor aangewezen het bestuurslid E. B. Kielstra, die verklaart de benoeming te aanvaarden.

Niets meer aan de orde zijnde, wordt de vergadering hierop gesloten. 